\title{
برنامج تدرييي للطالبة المعلمة لتصميم المجلة المصورة اللازمة لتقديم مهارات التعايش للأطفال المعاقين عقليًا (القابليز للتعلم)
}

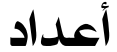 \\ د فاطمة شحته عايل \\ مدرس بقسم العلوم الأساسيتة
}
المجلت العلميتّ لكليت رياض الأطفالـ جامعت المنصورة
المجلد الخامس ـ العدد الأول

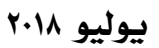




\section{برنامج تدربيي للطالبة المعلمة لتصميي المجلة المصورة

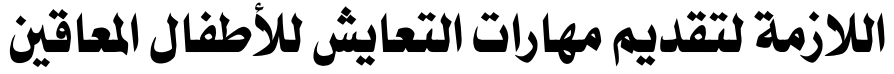 عقليًا (القابليز للتملم)}

\section{د / فاطمتش شحته عايد}

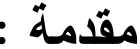

تعد الإعاقة من المشكلات متعددة الأبعاد، إذا لا تقتصر آثارها على الطفل

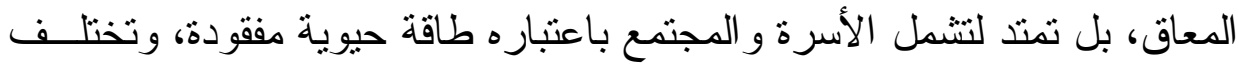

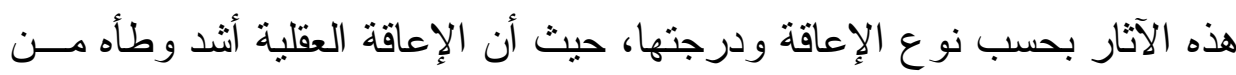
الإعاقة الجسمية، فكلما الشتنت درجه الإعاقة زادت معوقات الاندماج الاجتماعي

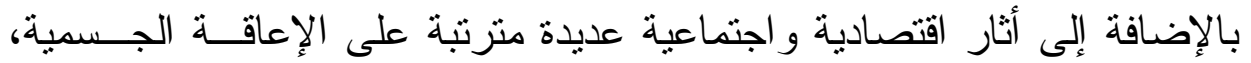

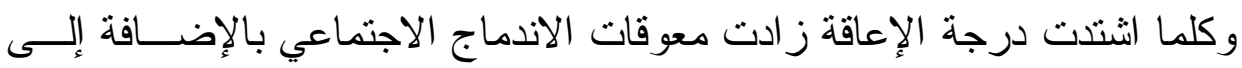

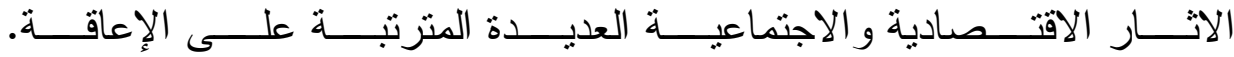

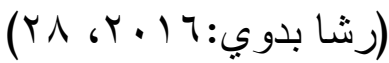

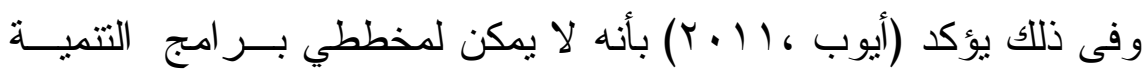

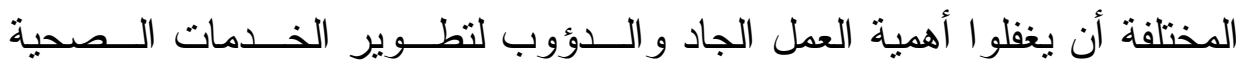

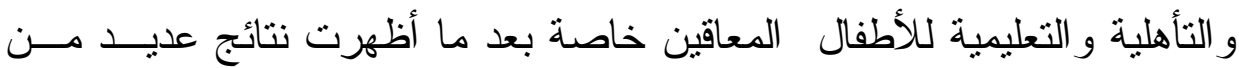
الدراسات و المسوح المحلية زيادة أعداد الأطفال العاقين عقليًا، إذا تحتل الإعاقة

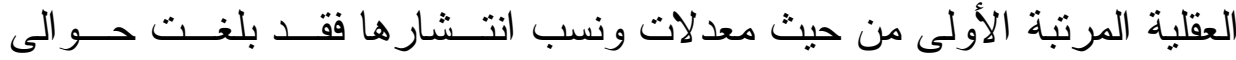

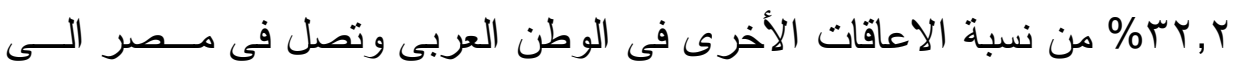

* مدرس بقسم العلوم الأساسيتة




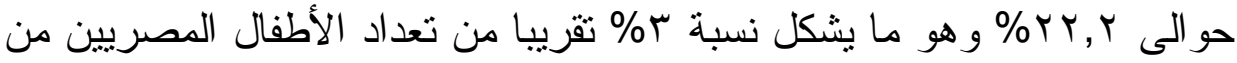

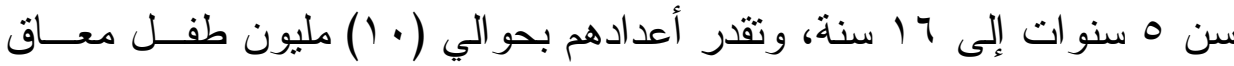
تقريبًا.

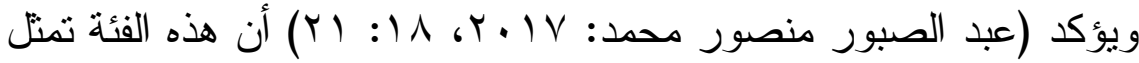

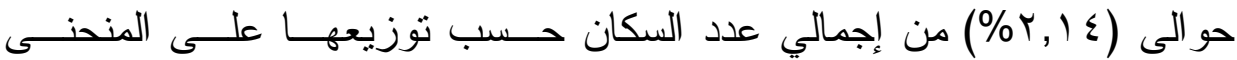

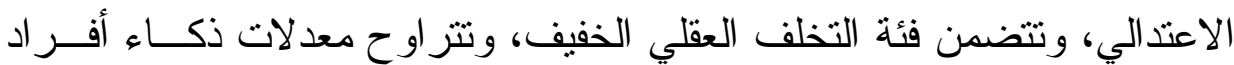
هذه الفئة ما بين (•V-V - V) على أحد مقاييس الذكاء المقننة، ويمكـنهم تحــصيل قدر من التعليم حتى مستوى الصف الخامس الابتدائي تقرييًا، وهم لا يسنطيعون

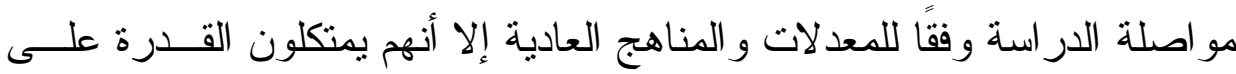
التعلم بدرجه ما إذا ما تو افرت لهم خدمات تربوية، فهم يتعلمون بــبطء شــديد، لذلك يمكنهم تعلم المو اد الدر اسية المقررة في سنة دراسية واحدة منلما هو الحال

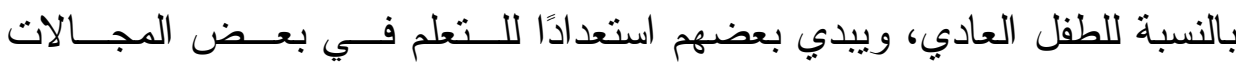
المهنية، لذا يمكنهم ممارسة بعض الأعمال والحرف التى يسنطعون عن طريقها

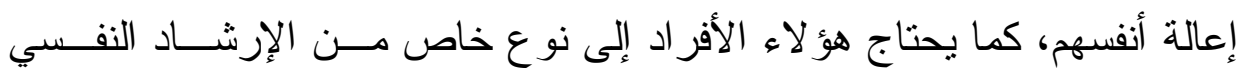
لمو اجهة الأزمات الرئيسية في الحياة.

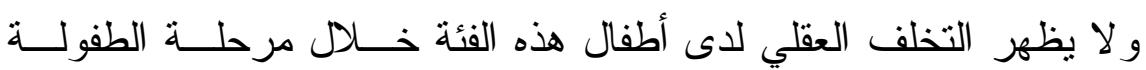

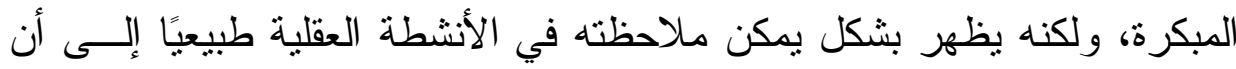
يظهر عجزه عن التعلم في الددرسة.

قام شارون (SHARON: 2008) بدر اسة أهمية مساندة معلمي التربيــة الخاصة الذين بدرسون للأطفال ذوى القدرات العقلية المنخفـــة فـــي بيئسات

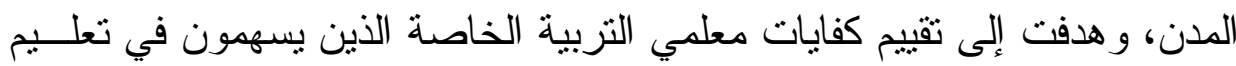


ذوى الإعاقة العقلية في مختلف أنحاء البلاد، وتثتير البحوث إلى تدني ظــروف

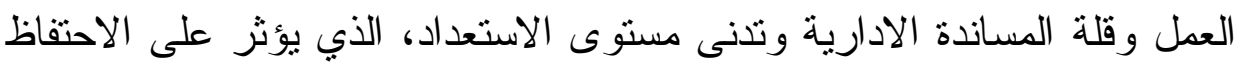
بعدد من معلمى التربية الخاصة لتدريس ذوى الإعاقة العقلية، وهدفت أيضًا إلي الي الئاسيا

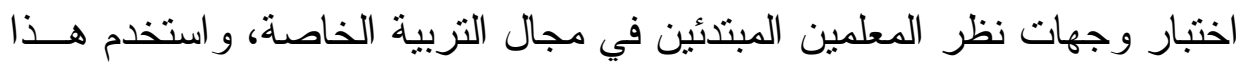
البحث النوعي طريقة دراسة الحالة لمقابلة معلمي التربية الخاصة العاملين فـى فـى نماذج خدمة مختلفة وتكونت عينة الار اسة من معلمين مبتدئين وقــــامى مدــن يعملون على تدريس الطلبة ذوى الإعاقة العقلية في بيئة نيوجرسي، وتوصـلت لـات

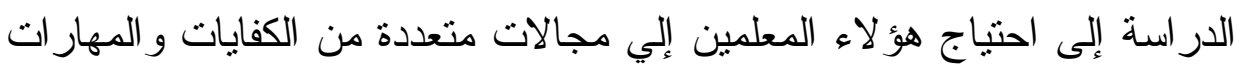
للتنريس للطلبة ذوى الإعاقة العقلية.

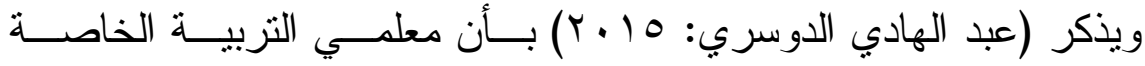

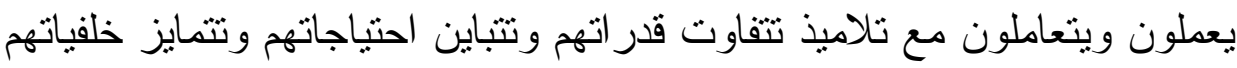
الاجتماعية والاقتصادية و الثقافية، وفي أغلب الأحيان يـتـت تـــريب المعلديـين

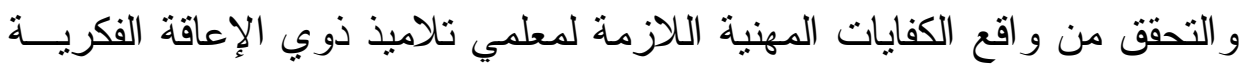

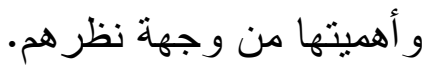

كما تبنت الجمعية الأمريكية للإعاقة العقليــة و التطوريــــ Association American Intellectual Developmental Disables 2008 موقفاً مطالبا

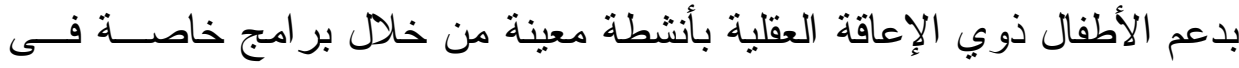

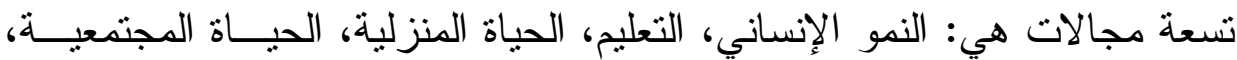

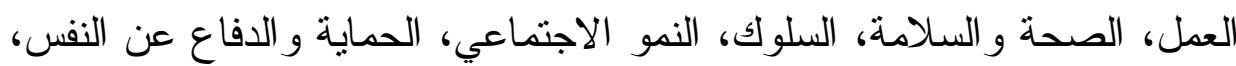

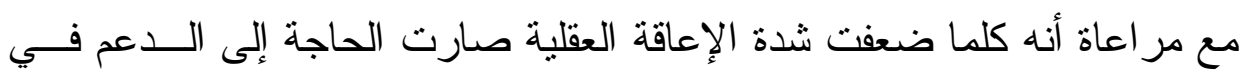

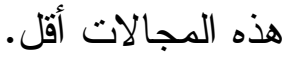


ونظرًا لأن الإعلام بوسائطه المختلفة هي التقافة بين كافـــة المجتمعـات

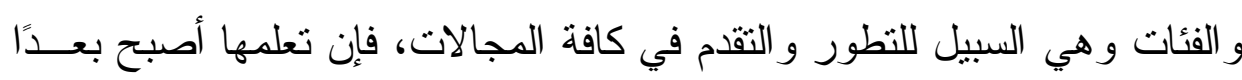
أساسيًا و لازمًا لإعداد الفرد إعدادًا يمكنه من مو اجهة العديد من مشكلات الحيــاة فئاة اليومية التي يمر بها.

ولقد أوصت العديد من المؤتمرات التي عقدت بهدف الاهتمــام بالأطفــال

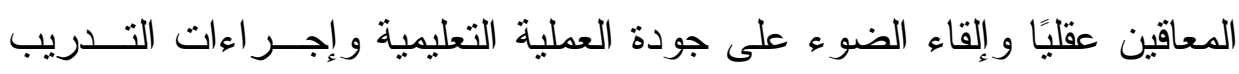

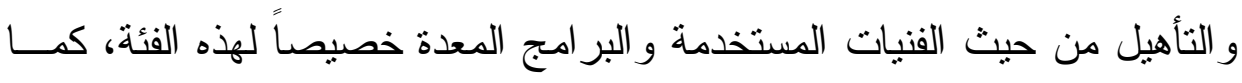

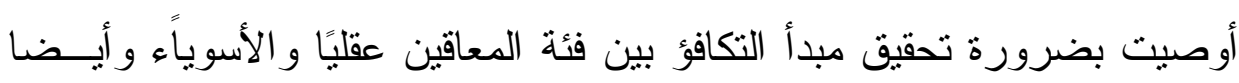

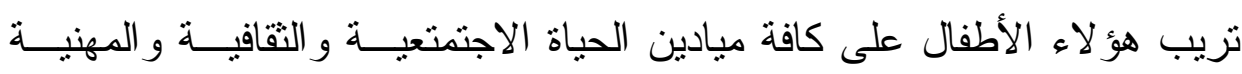

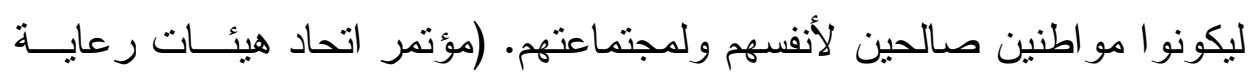

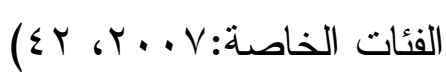

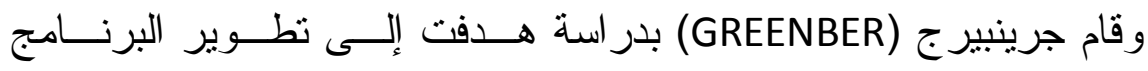

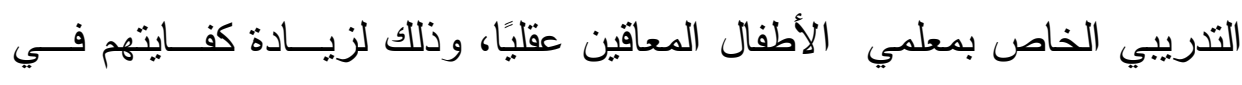

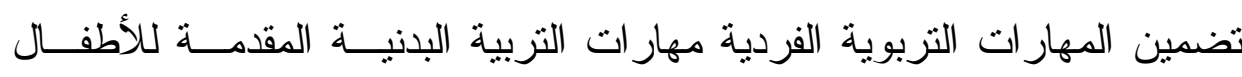

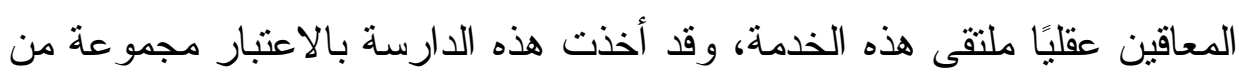

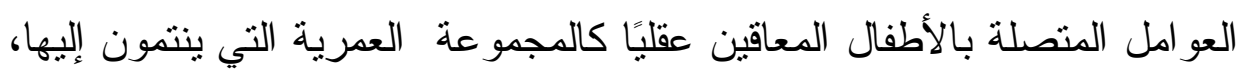

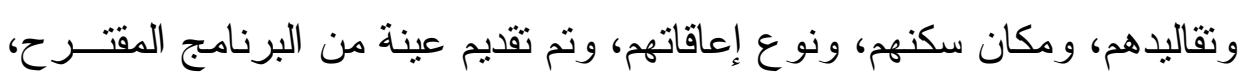

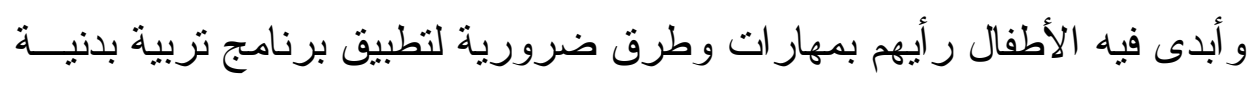
شامل للأطفال المعاقين عقليًا.

ويمكن تعريف مهار ات التعايش بأنها أحد نماذج السلوك المعرفي، و الذي

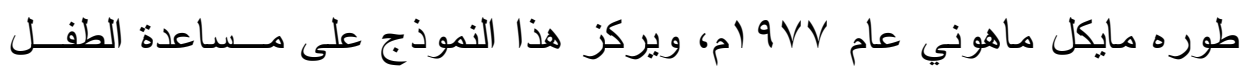


على اكتساب مهارات التعايش مع ظروف الحياة اليومية وتطوير المهار ات التى

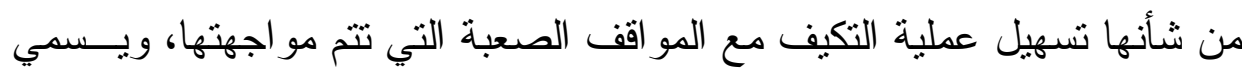

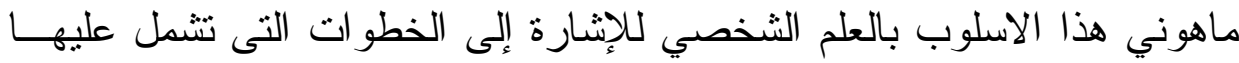

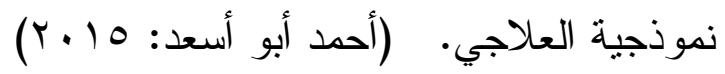

ويؤكد (يونس محمد: ؟ . . ب) على أهمية التعرف على وجهات نظر من

المتخصصين في ميدان الطفل وثقافته، ولذلك قام بدراسة تقويمية شاملة لهجلة حاتم للأطفال الصادرة عن المؤسسة الصحفية الأردنية "الر أي"، وقد أثنارت

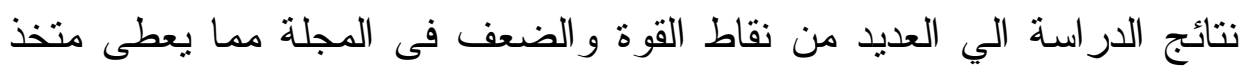
القرار فى مجلة فرصة لتعزيز نقاط القوة وتلافى نقاط الضعف عند إصدار

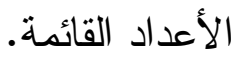

وأضاف (محمود قاسم: ^ . . ب) بانعدام وجود مجلات للأطفال في العالم الأقل ثقافة، و إنما قد أستلههنا الفكرة من ثقافه العالم الأكثر اهتمامًا بالثقافة،

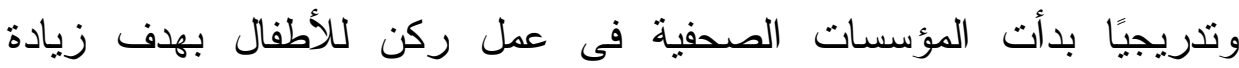

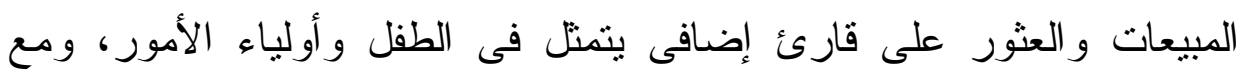
انتتار المجالات فى القرن العشرين انتهت المؤسسات التعلمية إلي أهمية الثقافة

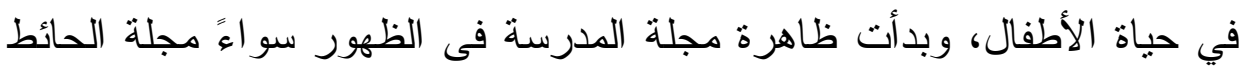

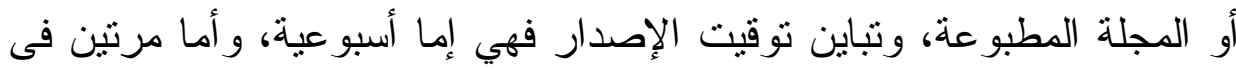

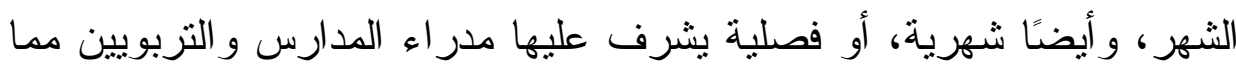

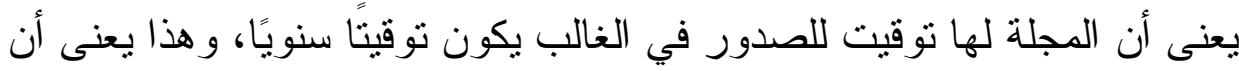
المجلة فى كل الأزمنة و الأمكنة لا تصدر كل يوم، فذللك منسوب الى الصحفية

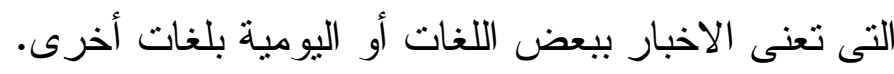




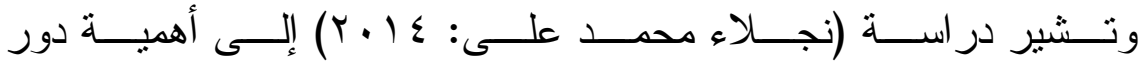

الانثطة المصورة فى مجلات الأطفال على تتميــة بعـض مهــار ات الإدر الك الك البصري لدى طفل الروضة، واعتبار الصور و الرسوم من أنو اع الوسائل التـى لإلى التى

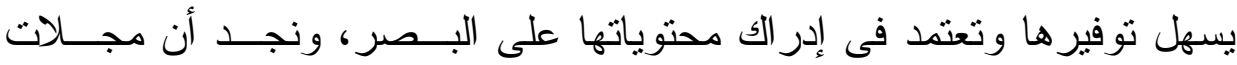
الأطفال تعتمد بشكل أساسي على تصوير المعاني وتجسيدها من خلال الــصورة إنسات

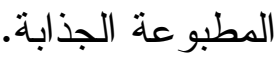

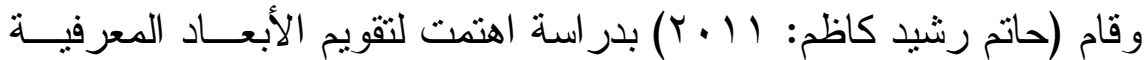
و الجمالية فى تصميم أغلفة مجالات الأطفال و أكد على وجود أليات التقويم سعيًا

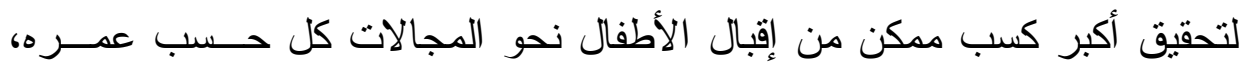
وتطوير قدر اتهم الذوقية و المعرفية وفق المنظور الصيحيح لتأسيس جيل يمكـن التبن

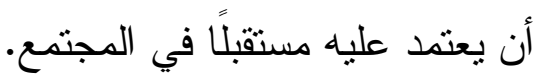
و أكدت دراسة (لمياء البحيري: ؟ . . ץ) في الكثف عن مظاهر المنافـسة

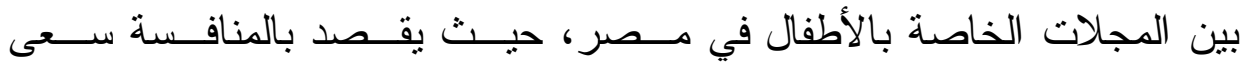

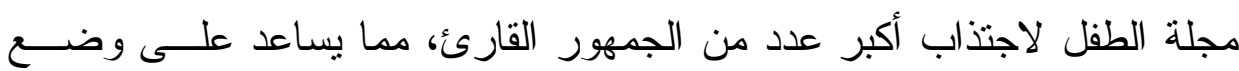

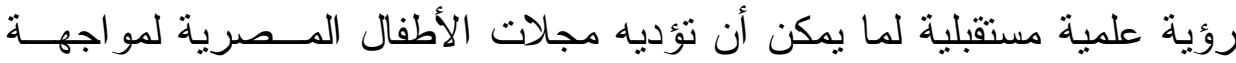

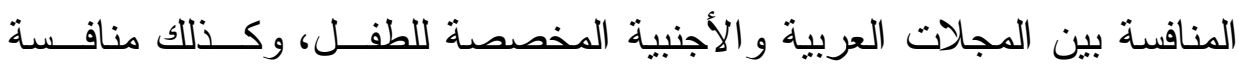

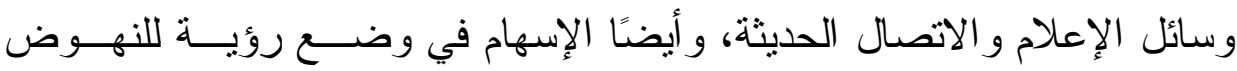

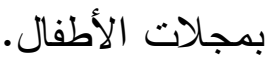

كما وضع (Donald: 1977) توصيف للمجــلات الموجهــة للأطفــال و المر اهقين ومعلومات عن هذه المجلات التي توز ع علــى مسستوى الو لايــات

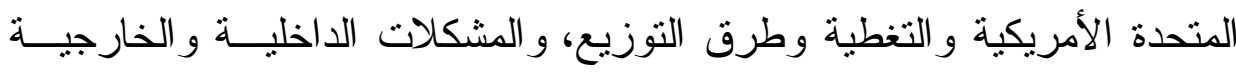


وحلها، وما تتصف به من خصائص متلك: المرونة و الإدر الك الجيـــــ والمقاومـــة الانفعالية و البحث عن المعلومات و الثقة بالنفس وما تحتويه من مهار ات تعسايش و التي تساعد بدورها في حماية الفرد وتحقيق التوازن لديه.

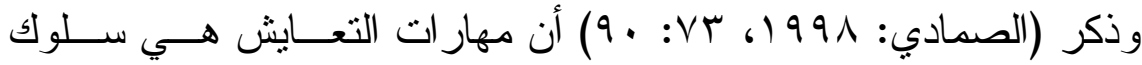
مكتسب مقبول اجتماعيًا يمكن الفرد من التعامل مع الآخرين و التفاعل معهم فـي

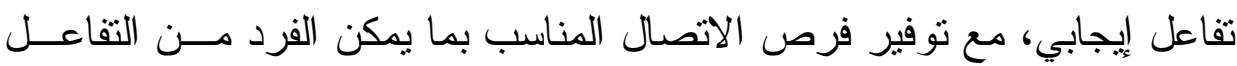

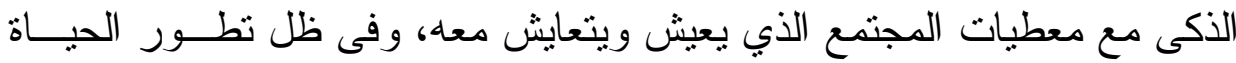

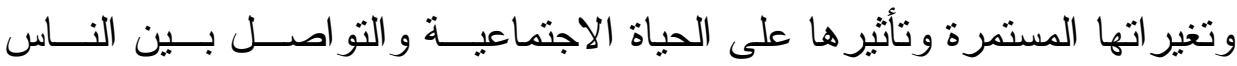

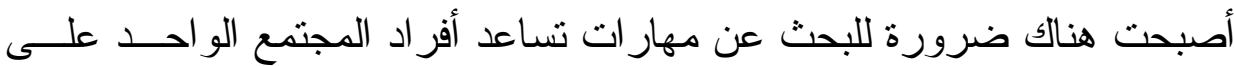

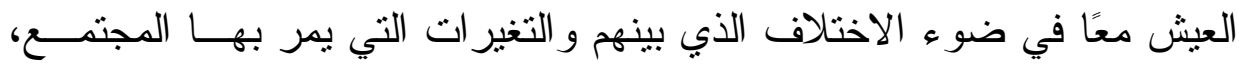

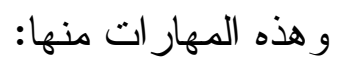

1. مهارة مخاطبة قلب وعقل الأخر ومخاطبة الدو افع النبيلة و التى تتـضمن المهار ات الفرعية التالية: (الاحتر ام- التقدير للآخر -التسامح-البحث عـن التحن

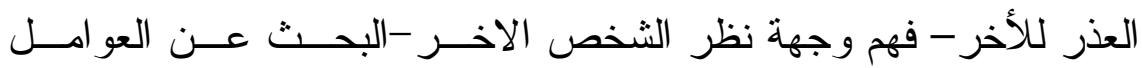

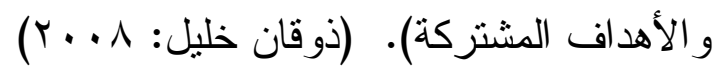

r. مهار ات التحدث و الأقتاع و التي تتــضمن المهــار ات الفرعيــة التاليــة: (التحدث أقل و الأستماع أكثر -الإصغاء باهتمام وتجنب الاعتقاد بــامتلاكل

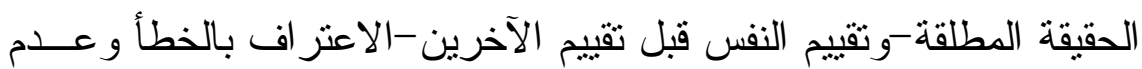

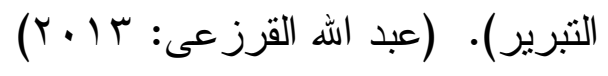




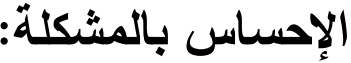

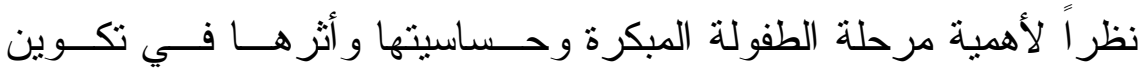
مهار ات الطفل، و استتادًا لأهمية الأنشطة المختلفة فى حياة الأطفــال المعـاقين

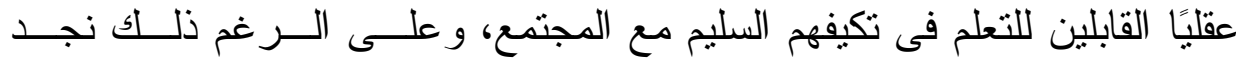

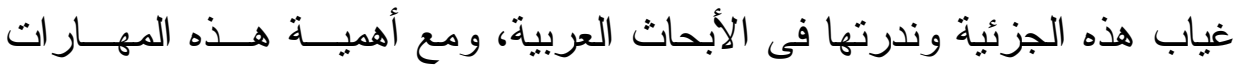

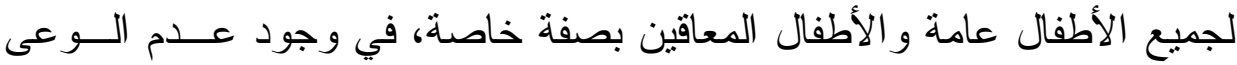

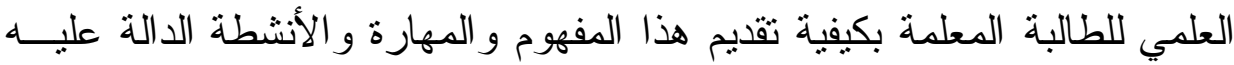
باستخدام الوسائل الإعلامية في تتمية مهار ات التعايش لاى الأطفــال المعـاقين

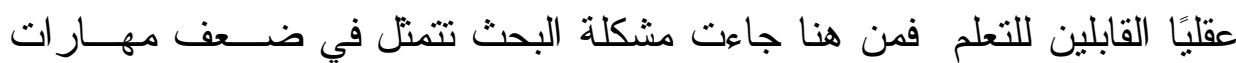
الطالبة المعلمة في تصميم مجلة مصورة لتقليم مهار ات التعايش لدى الأطفــال المعاقين عقليًا.

\section{وينبثق من السؤال الرئيس التساؤلات الفرعية الآتية:}

ا. ــا مهار ات التعايش التي يمكن تقديمها للأطفال المعاقين عقليًا القـــابلين

$$
\text { للتعلم؟ }
$$

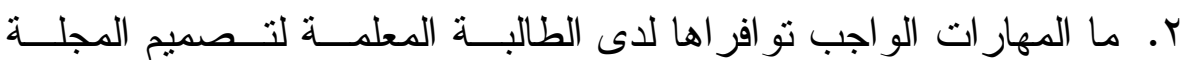

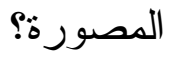

r. كيف يمكن بناء برنامج تدريبي للطالبة المعلمة لتصميم المجلة المصورة

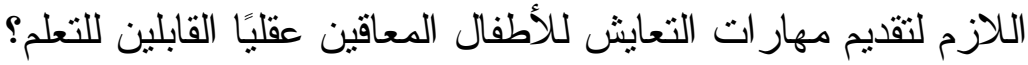

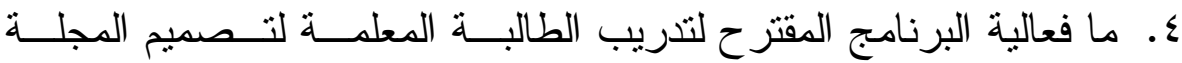

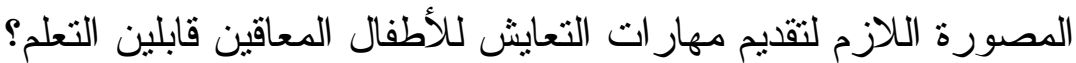




\section{أهداف الار اسةة: - إن}

ا. إعداد قائمة بمهار ات التعايش التي تجب تقديمها للأطفال المعاقين عقليًا.

قابلين التعلم

ك. تحديد مهار ات الو اجب نو افر ها لدى الطالبة المعلىــة لتـصميم المجلـــة

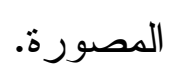

r. بناء برنامج تدريبي للطالبة المعلمة لتصميم المجلة اللازمة لتقديم مهار ات التعايش للأطفال معاقين عقليًا القابلين للتعلم.

ع. تعرف فاعلية البرنامج التدريبي للطالبة المعلمة لتصميم المجلة المصورة

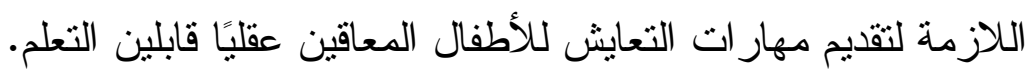

$$
\text { أهمية الدر اسةة: }
$$

1. تسهم المجلة المصورة كوسيلة جذابة لتنمية بعض مهار ات التعايش.

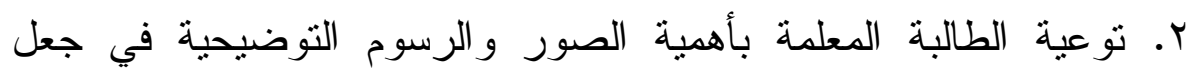

الأنشطة المقدمة للأطفال المعاقين عقليًا القابلين للتعلم أبقى أثرًا.

r. اخضاع الأنشطة المصورة في مجالات الأطفال المعاقين لخدمة الأهداف

$$
\text { التربوية الني نسعى لتحقيقها. }
$$

ء. الطفل المعاق عقليًا فئة القابلين للتعلم حينما يطبق عليه المجلة المصورة

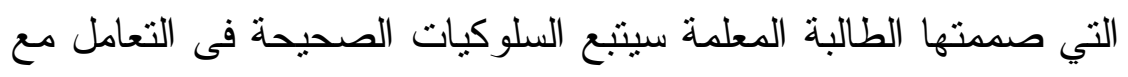
الآخرين ومع البيئة من حوله، وهذا ما يهدف البحث إليه. 


$$
\text { أدوات ومواد الداراسة: }
$$

ا. استبانة مهار ات التعايش التي يجب أن تتو افر لدى الأطفال المعاقين عقليا

$$
\text { القابلين للتعلم. (إعداد الباحثة). }
$$

r. قائمة مهار ات التعايش اللازمة للأطفال المعاقين عقليًا (القابلين للتعلم).

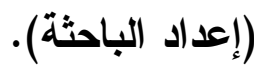

r. بطاقة ملاحظة لأداء الطالبة المعلمة أثناء تــصميم المجلــة المـصورة للأطفال المعاقين عقليًا القابلين للتعلم. (إعداد الباحثة).

ع. مقياس تصميم المجلات المصورة لمهـار ات التعـايش لــدى الأطفــال

$$
\text { المعاقين عقليا القابلين للتعلم. (إعداد الباحثة). }
$$

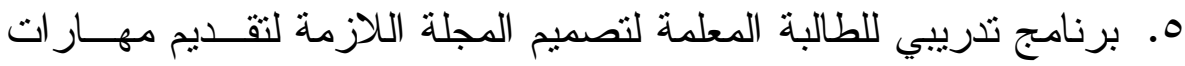
التعايش للأطفال معاقين عقليًا القابلين للتعلم. (إعداد الباحثة).

$$
\text { حدود الار اسـة: }
$$

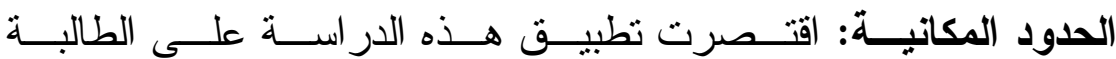

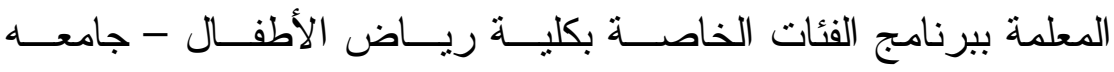

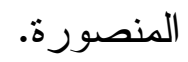

الحدود الزمانية: تم نطبيق هذة الدراسة فى الفصل الدراسى الثانى للعام

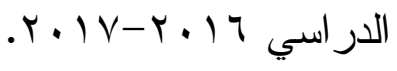

الحدود البشرية: اقتصرت الدر اسة على الطالبة المعلمة بيرنامج الفئـات

$$
\text { الخاصة بكلية رياض الأطفال جامعه المنصورة. }
$$


ثم منهج الداسة: استخدت الباحثة المنهج شبه التجريبي - التصميم

التجريبي ذو المجموعتان-مجموعة تجريبية واحدة، ومجموعة ضابطة لمعرفة تأثير المتغير المستقل (تصميم المجلة المصورة) على المتغير التابع (مهار ات التعايش اللازمة للأطفال المعاقين عقليًا القابلين للتعلم).

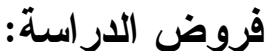

تحاول الدراسة الحالية اختبار صحة الفروض التالية:

1- يوجد فرق ذو دلالة إحصائية عند مستوي (0., ) بين متوسطي درجات

طالبات المجمو عتين (التجريبية و الضابطة) في النطبيق البعـدي لمقيــاس

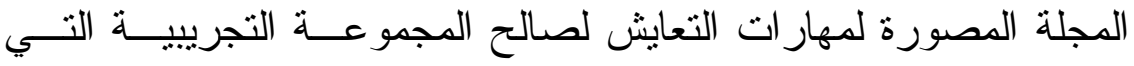
درست بالبرنامج المقتر ح.

Y- يوجد فرق ذو دلالة إحصائية عند مستوي (0., •) بين متوسطي درجات

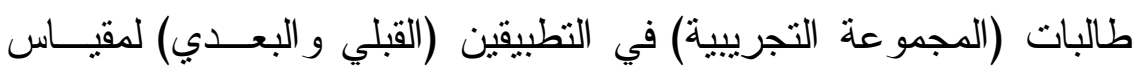
المجلة المصورة لصالح النطبيق البعدي. r- يوجد فرق ذو دلالة إحصائية عند مستوي (0., •) بين متوسطي درجات

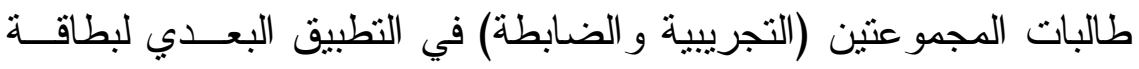

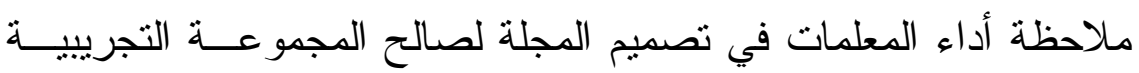
التي درست بالبرنامج المقتر ح. ع- يوجد فرق ذو دلالة إحصائية عند مستوي (0 •، •) بين متوسطي درجات

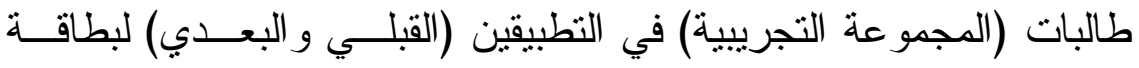
ملاحظة أداء المعلمات في تصميم المجلة لصالح التطبيق البعدي. 
0- توجد علاقة ارتباطية موجبة عند مستوي (0 •، • ) بين تحصيل الطالبــات

(المجمو عة التجريبية) لمهار ات تصميم المجلة، و امتلاكهم لتلك المهار ات.

\section{مصلحات البحث:}

\section{1 - المعاقين عقليًا القابلين للتعلم:}

وتعرف إجر ائيًا بأنها الإعاقة التي يكون الأداء العقلي لطفل الروضـــة دون المتوسط، حيث تبلغ نسبة ذكائه حو الي • V أو أقل وذلك على أحد مقــاييس الذكاء الفردية للطفل و عادة ما تكون مصحوبة بخلل فـى ســلـوك الـذكاء التكيفي وذلك خلال سنوات النمو، فلا يصل الطفل الى المعــايير الـسلوكية المتوقعة من الأطفال في مثل عمره الزمني، ويركز البحث الحــالي علـى الأطفال القابلين للتعلم و التى تتر اوح نسبة ذكائهم على • ع على أحد مقاييس الذكاء الفردية المقننة.

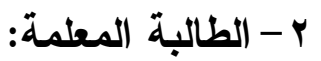

يقصد بها المعلمة المتخصــصة فـي التزبيــة الخاصــة علـى مـستوى البكالوريوس، و التي ستقوم بتعليم وتدريس الأنشطة التعليمية للأطفــال ذوي الإعاقة العقلية البسيطة القابلين للتعلم، من خلال استخدامها لبعض الوسائط الإعلامية التي قامت بتصميمها لتقديم أنشطة تعليمية تتمى مهار ات التعايش

$$
\begin{aligned}
& \text { لدى هؤلاء الأطفال. } \\
& \text { r-مهار ات التعايش }
\end{aligned}
$$

هي المهار ات التي يستخدمها الفرد للتو اصل و التفاعل الإيجابي مع الآخرين المختلفين عنه، من خلال بعض الوسائط الإعلامية المحبية الى الطفل 
المعاق عقليًا القابلين للتعلم باستخدام المجلة المصورة التي تتسم بالصورة

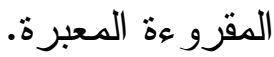

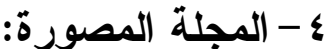

مطبوعة دورية تقدم للطفل الفنون، والمعارف، والآراء، والصور المختلفة،

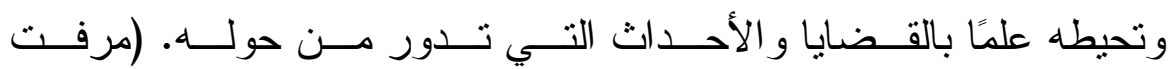

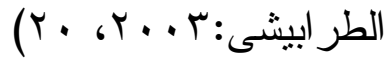

$$
\begin{aligned}
& \text { وتعرفها الباحثة إجر ائيا: }
\end{aligned}
$$

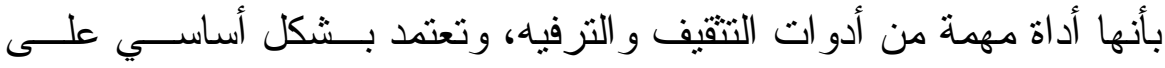
الأنشطة المصورة باستخدام الصورة كلغة بصرية يستطيع الأطفال المعاقين عقليًا القابلين للتعلم فهمها وقر اءتها مهما أختلف مستويات تعلمهم، وذلك من بلكن خلال مجموعة من الأنشطة المصورة و التي تعتمد على معرفـــة الكلـــات،

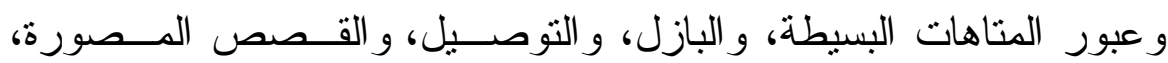

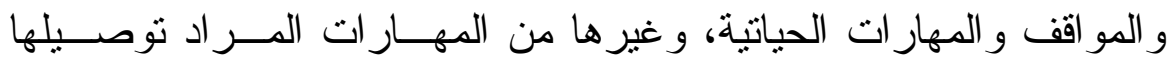
لأطفال هذه الفئة.

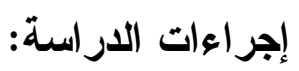

$$
\text { 1. الاطلاع على الدر اسات و البحوث و الكتابات السابقة. }
$$

r. اثتقاق قائمة مهار ات التعايش الو اجب نو افرها لدى الأطفــال المعـاقين

عقليًا القابلين للتعلم.

r. وضع القائمة فى صورة استبانة وعرضها على المحكمين وتعديلها فـي

$$
\text { ضو ء ملاحظاتهم. }
$$


ء. إعداد قائمة مهار ات التعايش الو اجب تو افرها لدى الأطفال المعاقين عقليًا

القابلين للتعلم لتصميم المجلة المصورة، و عرضه على المحكمين.

ه. صياغة قائمة مهار ات التعايش فى صورتها النهائية.

7 . . إعداد مقياس مهار ات التعايش الو اجب تو افره لــدى الطالبــة المعلمـــة

لتصميم المجلة المصورة اللازمة لتقـديم مهــار ات التعـايش للأطفــال

المعاقين عقليًا القابلين للتعلم، و عرضهه على المحكمين.

V. الاطلاع علـى الدر اســات و البحــوث الـسابقة فـى مجــال تـصميم

المجلات بصفة عامــة و علـىى المجــلات المــصورة الموجهــة إلـىى

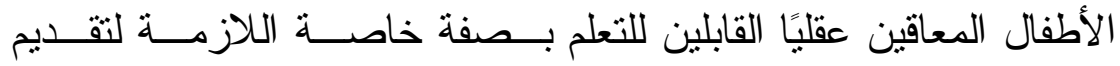

$$
\text { ^. مهار ات التعايث لهم. تحيد عينة الدر استة. }
$$

9

• إستخلاص نتائج التطبيق وتحليل النتائج.

ا ا. تقديم التوصيات و المقترحات فى ضوء النتائج.

أدبيات الدر اسةة

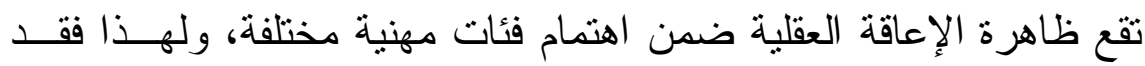
حاول المختصون في ميادين الطب، و الاجتماع، والتربية، وغيرهم التعرف على هذه الظاهرة من حيث طبيعتها، ومسبباتها، وطرق علاجهــا، ومــن الــصعوبة الوصول إلى تعريف الإعاقة العقليــة يتــصف بالدقــة العلميـــة و المهنيـــة ذات التخصصات المختلفة، وقد يكون من المناسب استعر اض أبرز التعريفات المهنية 
للإعاقة العقلية وصو لا إلى التعريف الذي نعتبره أكثر قبو لا عن غيره لموضوع

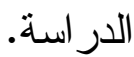

يعرفها (Pugach, M.c.:2001, 219:220) تعتبر الإعاقة العقلية هي نقص أو قصور في أداء الفرد تظهر قبل الثانية عـشر مــن عمــره، ويكـون مسبياتها ور اثية، أو بيئية، أو الأثتين معا، ويظهر القصور في ضــــف القــدرة العقلية لدى الفرد، ويبلغ متوسط ذكائه ، V درجة فأقل، كما يعـاني مسـن ســوء التكيف.

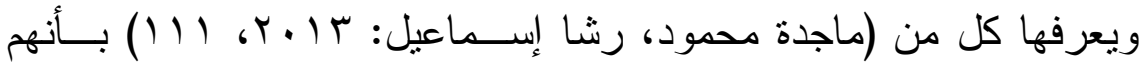
مجموعة من الأطفال المعاقين عقليًا القابلين للتعلم وتتر اوح نسبة ذكــائهم بــين

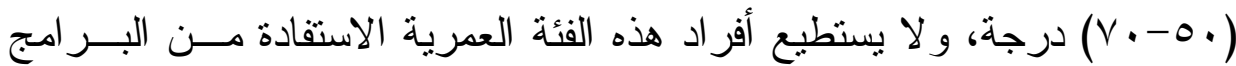
التزبوية في المدارس العادية في نفس الفئة العمرية، ويمكن لأفر اد هـــذه الفئــة بالاستعانة بالبر امج التزبوية الخاصة بالوصول إلـى مـسـتوى الــصف الثالـــث الإبتدائي ويتز اوح العمر العقلي لأفر اد هذه الفئة من(7-9) سنوات.

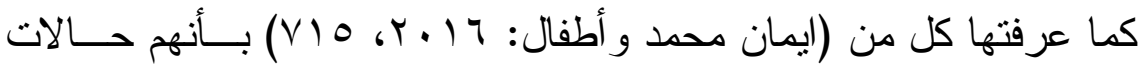
التخلف العقلي البسيط، ويمتلون حوالي ع ا, ب\% من إجمــالي عـدد الـسكان،

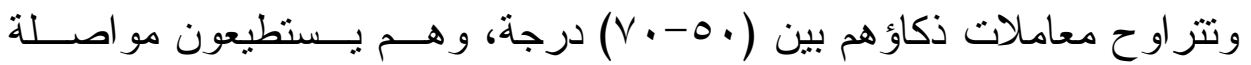

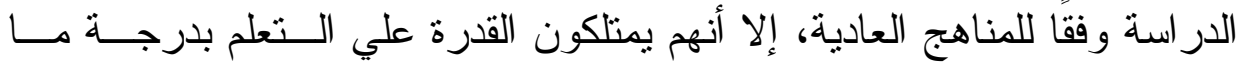

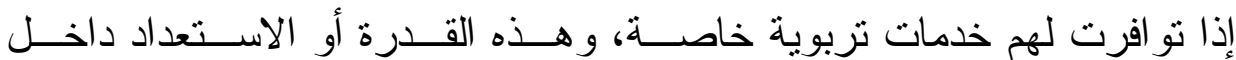
بيئة تعليمية ملائمة - مدارس أو فصول خاصة بهم - وغالبــا لا بـستطيعون

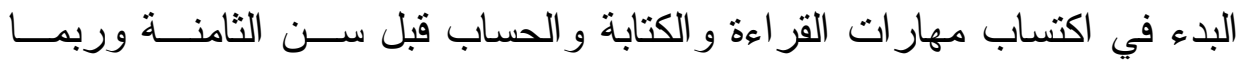
• الحادية عشر 


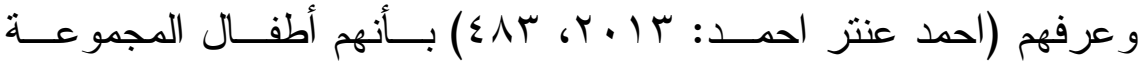

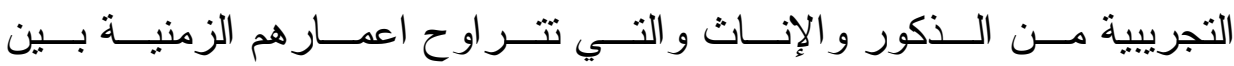

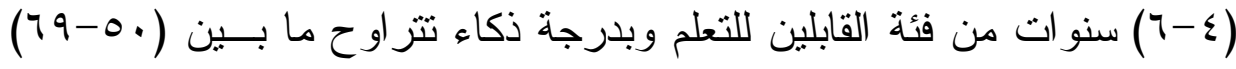

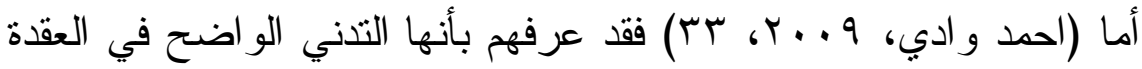

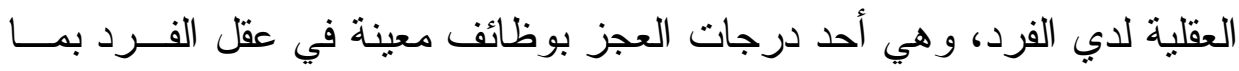

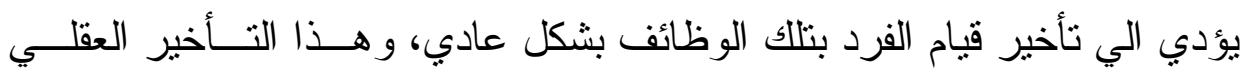
يؤدي إلى اضطر اب علاقات الفرد بنفسه أولًا وبمحيطه في الزمان وانئ و المكان. كما نص تعريف الجمعية الأمريكية للإعاقة العقلية علـى إنهــا: إعاقـــة

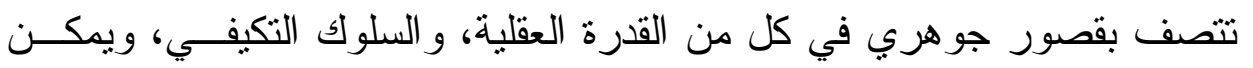

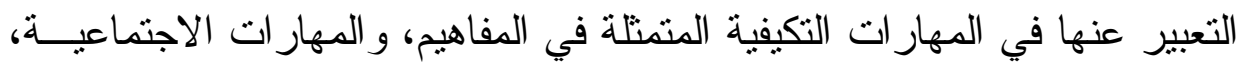

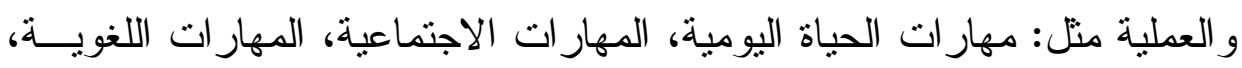

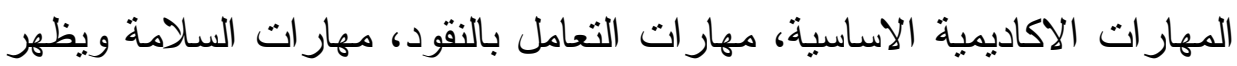
هذا القصور قبل 11اسنة. (Luckasson,Schalock: 2004, 138) وعرفها سو لانكي و آخرون(solanki\& others: 2015,1-2) بأنها تثير

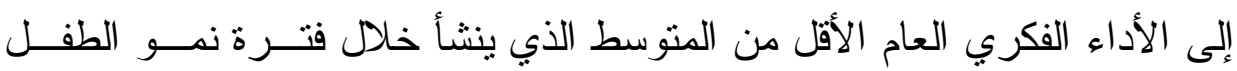

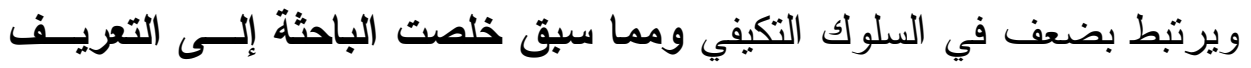
الإجرائي: بأنها الأداء العقلي لطفل الروضة دون دون المتوسط حيث تبلغ نسبة ذكائة

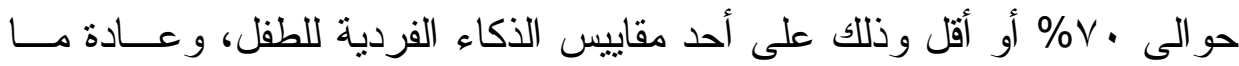
تكون مصحوبة بخلل فى السلوك الذكاء التكيفى، وذلك خلال سنوات النمو حيث

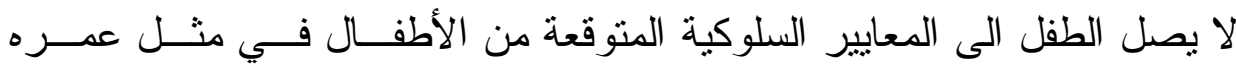


الزمني، ويركز البحث الحالي على الأطفال المتخلفين عقليًا القابلين للتعلم و الذين

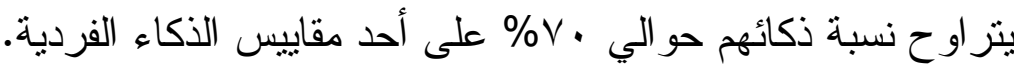
تصنيف الإعاقة: هناك من صنفها تربويًا الي ثناث فئات هي: لوفي 1. فئة القابلين للتعلم Educable mentally Retarded: أطفال هذه الفئة لا يستطيعون الاستفادة من البرامج التزبوية الخاصة بالعاديين، ويفضل تعليمهم باستخدام البرامج الفردية التي تتضمن بعض المهارات الحياتية،

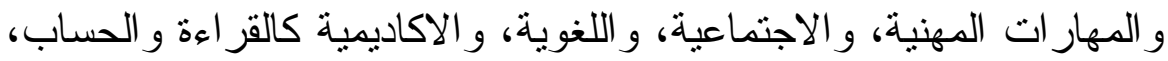
حيث تتر اوح معاملات ذكائهم ما بين (00- V. درجة، وهم بذللك يقابلون حالات التخلف العقلي البسيط.

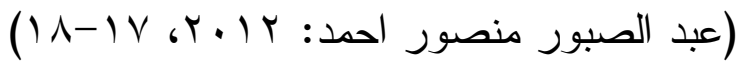

r. فئة القـابلين للتـدريب Trainable mentally retarded: تتـضمن

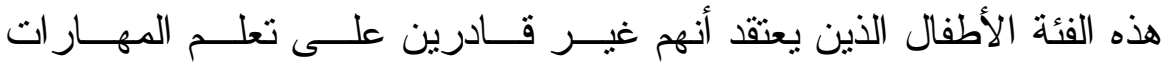
الاكاديمية، ولذا فان برامجهم التعليمية تهدف للتـدريب علـى المهــارات

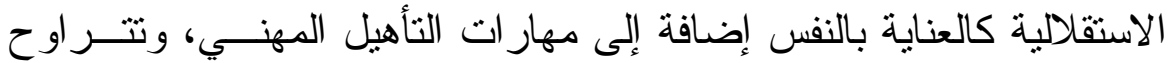

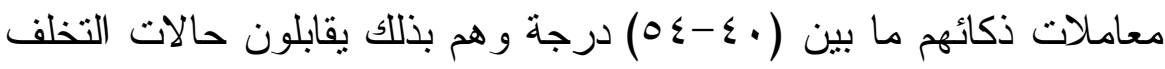
العقلي المتوسط. r. فئة الاعتماديون The Totally Dependent: تقـل معساملات ذكـــاء الأطفال الذين ينتمون الي هذه الفئة عن (Yo) درجة، وهم عـاجزون كليًا

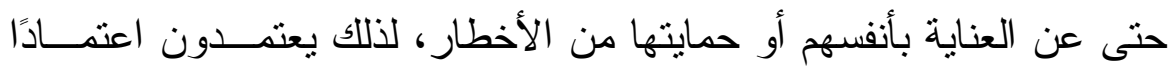

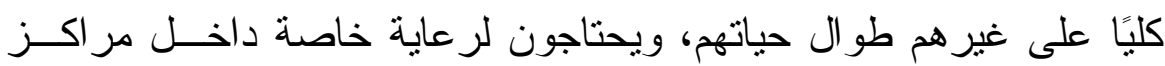

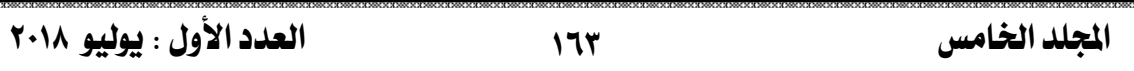


علاجية متخصصة أو مؤسسات إيو ائية خاصة. (ميرفت محمـود محمــد،

$$
\text { (r) } 6 \text { (r) } 10
$$

وفي ضوء التصنيف التربوي فقد تحددت عينة الدراسة وهي من الأطفال ذوي الإعاقة العقلية البسيطة القابلين للتعلم والتي تتر اوح معاملات ذكائهم مـــا

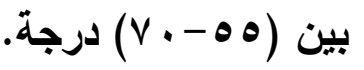

بطي التعلم: Slow learner

وتتز اوح نسبة ذكاء هذه الفئة بين ( •^: • و) درجة و هم قرييون جدا مسـن

العاديين ويحتاجون إلى رعاية خاصة لكي يتـساوو ا مـــع نظــائر هم العـاديين.

(Wells:2002, 71-72)

خصائص الإعاقة العقلية القابلون للتعلم:

$$
\begin{aligned}
& \text { 1. الخصائص العقلية } \\
& \text { Y. الخصائص الجسمية } \\
& \text { r. الخصائص الاجتماعية } \\
& \text { ء. الخصائص الانفعالية } \\
& \text { ا ـ الخصائص العقلية: }
\end{aligned}
$$

إن الأطفال المعاقين عقليًا لا يصلون في نموهم التعليمي إلـى المـستوي

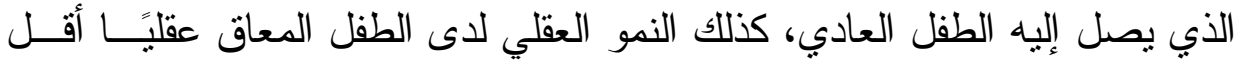
من معدل نموه من الطفل العادي حيث إن مستوي ذكائه يصل إلى ل V درجـــة،

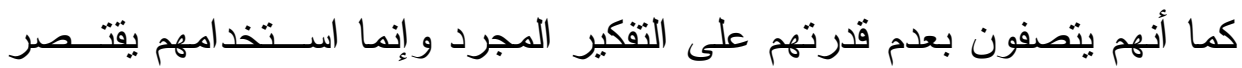

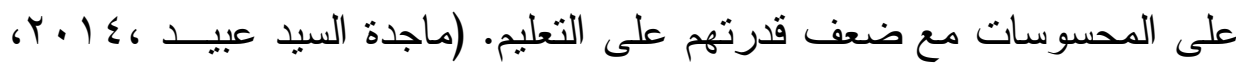


ومن أهم ما يميز الأطفال المعاقين عقليًا القابلون للتعلم من حيث الخـصائص العقلية ما يلي: - العم اليز

1. الميل نحو تبسيط المعلومات. r. بـ القور القدرة على التعليم.

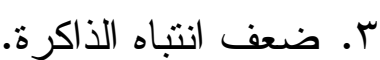

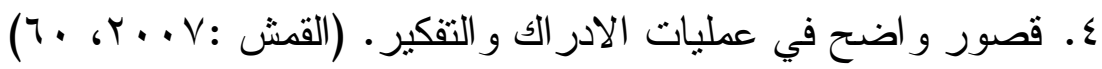

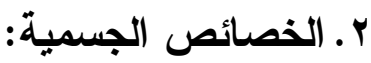

يميل معدل النمو الجسمي و الحركي للمعاقين عقليًا إلى الانخفاض بشكل

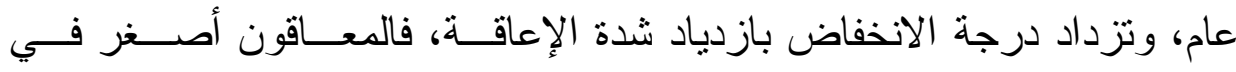

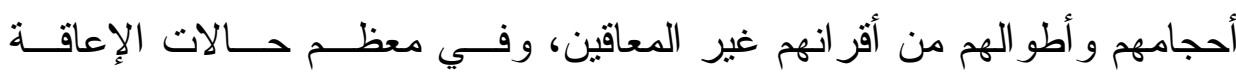

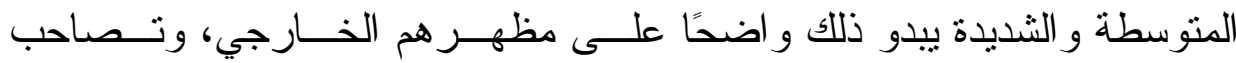

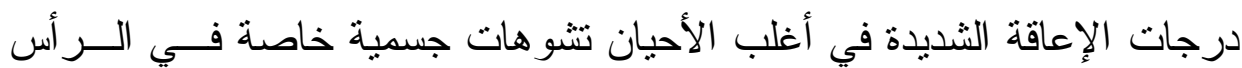
و الوجه، وفي أحيان كثيرة في الأطر اف العليا و السفلي.

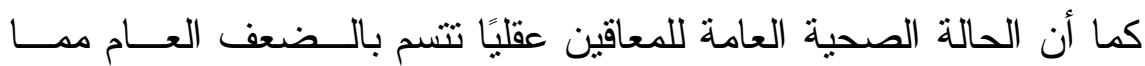

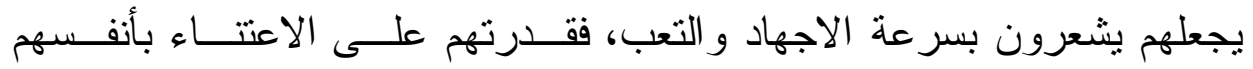

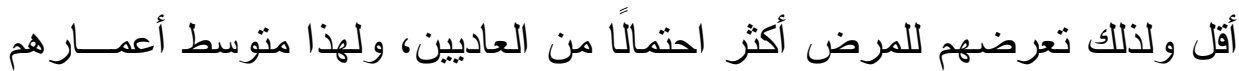

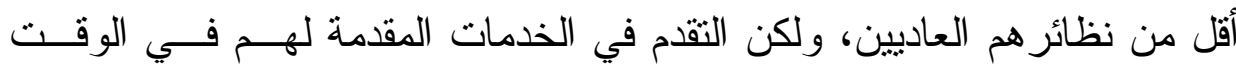

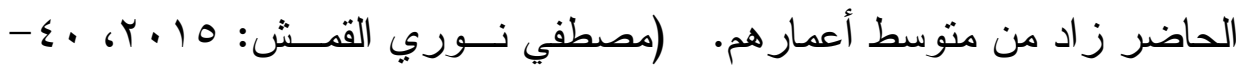


r. الخصائص الانفعالية

يتميز الأطفال المعاقين عقليًا القابلون للتعليم ببعض الصفات الانفعالية من أهمها ما بلي: سهولة الانقياد وسر عة الاستهو اء.

انخفاض تقدير الذات و المفهوم السلبي عن النفس.

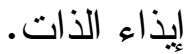
الجمود و التصلب. عدم الاهتمام بالعادات و التقاليد في المجتمع. • النزعة العدو انية و الأفعال المضادة للمجتمع. • العزلة و الانسحاب من المو اقف الاجتماعية. •التبلد الانفعالي، و اللامبالاة، و الاندفاعية، و عدم التحكم في الانفعالات،

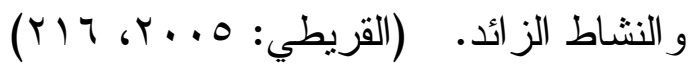

الابتعاد عن الجماعة، وعدم الاهتمام بتكوين علاقات اجتماعية وخاصة مع ابناء عمره، ولهذا فأنه يميل إلى المشاركة مع من هم أصغر منه سنًا

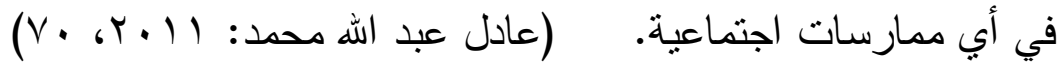
ع. - الخصائص الاجتماعية:

تعتبر المهار ات الاجتماعية من أهم المهار ات اللازمـــة لتكيــف الطفـلـل مع المجتمع، وتختلف مهار ات التفاعل الاجتماعي باختلاف المجتمــع المحـيط

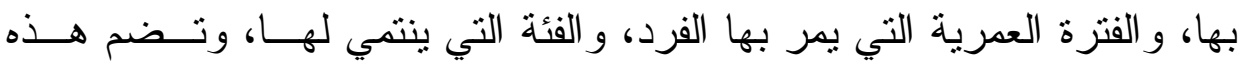

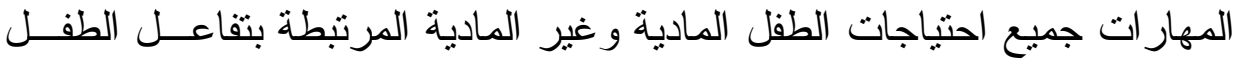
مع الحياة. 
وتوجد اختلافات جوهرية بين الأطفال المعاقين عقليًا و أنفسهم من حيــث

الخصائص الاجتماعية ومدى تكيفهم مع الآخرين، ونزجع هذه الاختلافات إلـى طبيعة التكوين النفسي لهؤلاء الأطفال، وظروف التنشئة الاجتماعية، و الخبــر ات السيئة التي يتعرضون لها في سباق تفاعلهم مع أفر اد المجتمع في البيئة الأسرية

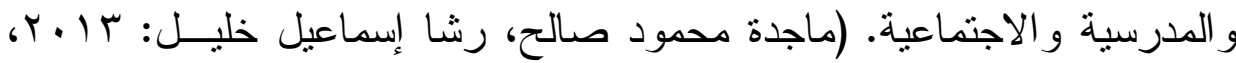

وتعتبر الخصائص الاجتماعية محصلة (نتاج) الاخــتلاف بـين توقعــات

المجتمع وقدر ات الطفل المعاق عقليًا و التــي يحتـــاج إليهــــا فــي ســعيه مــن أجل تحقيق متطلبات بيئته ومجتمعه، ومن أهم الخصائص الاجتماعية المميـزة

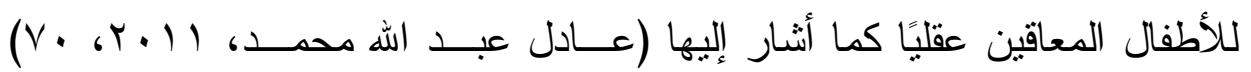
ما يلي:

قصور في الكفاءة الاجتماعية، وعجز عن التكيف مع تلــــ البيئــة التــي يعيشون فيها، صعوبة إقامة علاقات إيجابية مــع الآخـرين، ونقــص الميــول

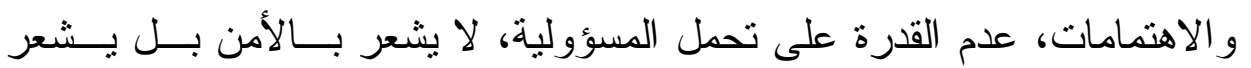
بالفشل المستمر و العجز وقلة الثأن، عدم تتاسب سلوكه مع ردود أفعاله لمستوى

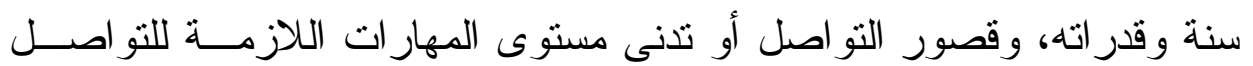
سواء اللفظي أو غير اللفظي، و عدم القدرة على المبادرة بالحديث مع الآخــرين، وصعوبة في التعلق بالآخرين و الانتماء إليهم، و أخيرًا قصور مهـــار ات العنايـــة

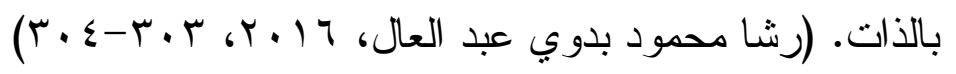
وفي الجانب الاجتماعي أيضًا نرى أن الأطفال المعاقين عقليًا يعانون مــن عجز في السلوك التكيفي الاجتماعي، ليس فقط بسبب أعاقته بل يعود أيضًا إلى 
نظرة الآخرين لهم وطرق معاملتهم، مما يؤدي بهم إلـى تـــنـي فـــي مفهـوم

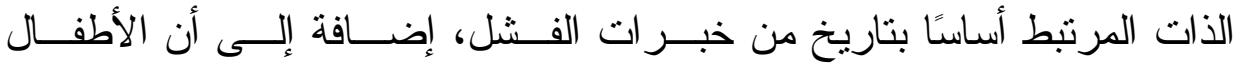

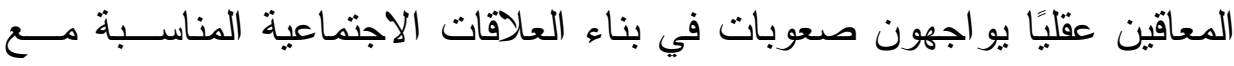

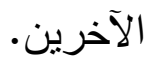

كما أن الطفل ضعيف العقل يجد صعوبة كبيرة في تكيفه مـــع المو اقــف الاجتماعية، فهو مضطرب في تفاعله الاجتماعي نظرًا إلى نقص اهتمامه بالعالم من حوله و انسحابه، وانطو ائه وسهولة قابليته للإيحاء وسهولة انقياده و إغر ائسـه ومن ثم انحر افه، ومن مظاهر اضطر اب مفهوم الذات لاى الطفل ضعيف العقل

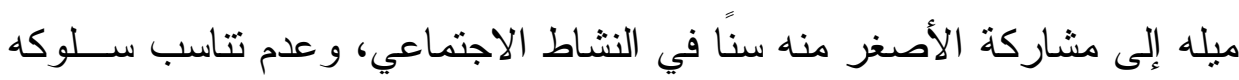

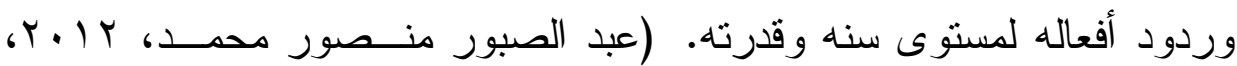
$(r \leq-r T$

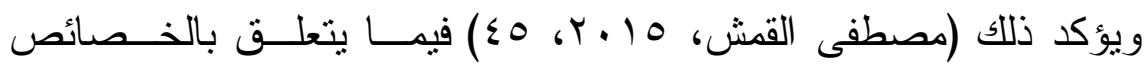
الاجتماعية، فيرى أن الأطفال المعاقين عقليًا يميلون إلـى اللعــب و المـشـاركة

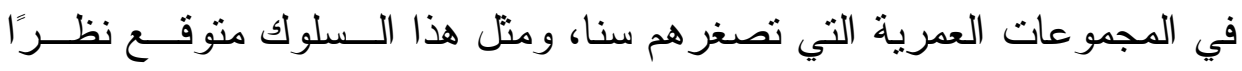

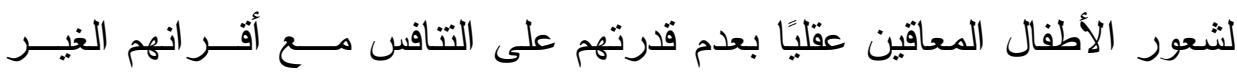
معاقين.

ومما سبق يمكن القول بأن عملية التعليم ترتكز بشكل عام، وفي التربيــة

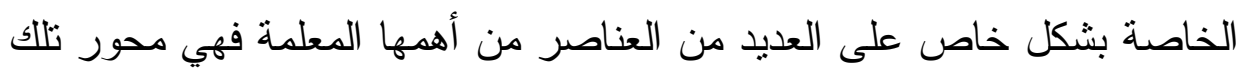

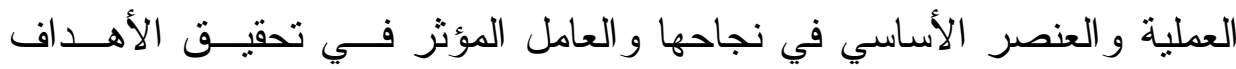

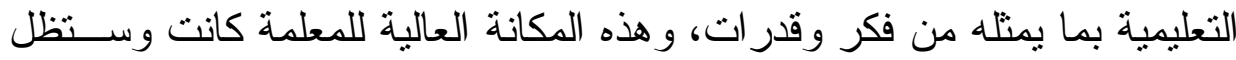

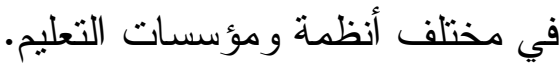




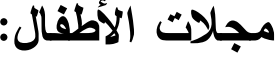

وقد تر افق إعداد المعلمين نطوير أدائهم مع التغييرات الملحوظة و الهامـــة

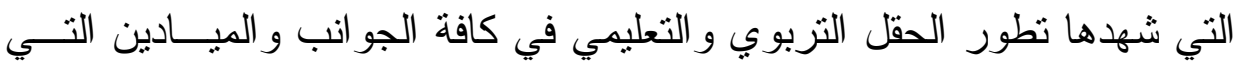

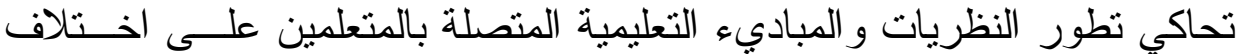

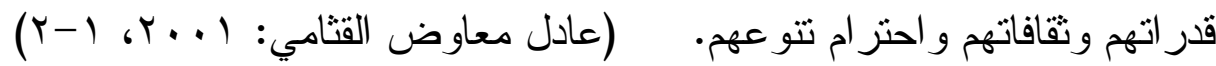
ولمَّا أصبحت نظرة المؤسسات و النظم التزبوية أكثر شمولية في وجــوب

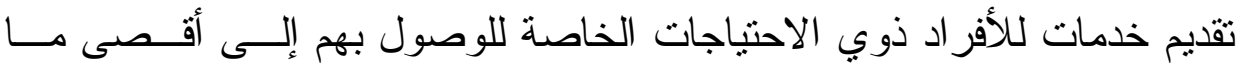
تسمح به قدر اتهم في الاسنقلالية و الحياة الكريمة، وجدت أنه من الأهمية بمكــان

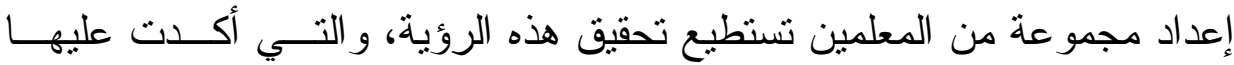
المو اثثق الدولية من حيث أن التعليم هو حق للجميع.

ومما سبق أصبح من الضروري الاهتمام بإعداد معلمات الفئات الخاصـــة

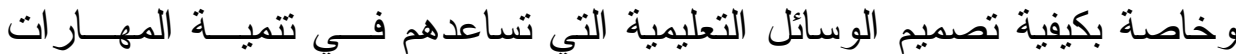

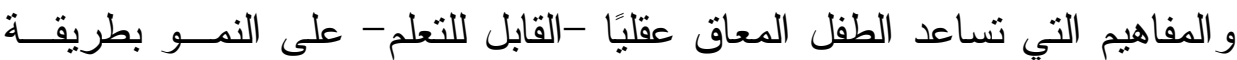

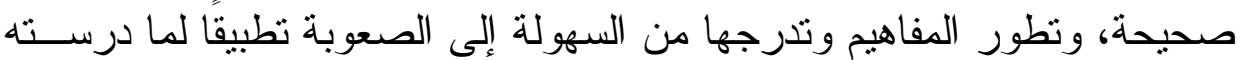
وخلفيتها المعرفية عن خصائص هذه الفئة من ذوي الاحتياجات الخاصة، ولــــا

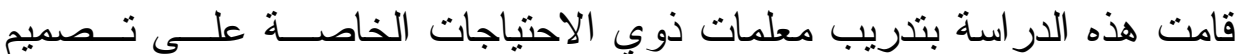
و استخدام المجلة المصورة كوسيلة محبية إلى الأطفال عامة و الأطفال مــن فئسـة

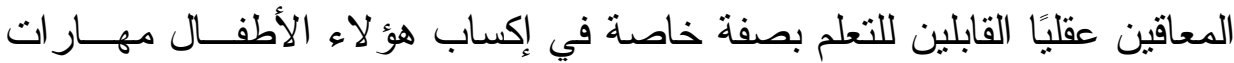

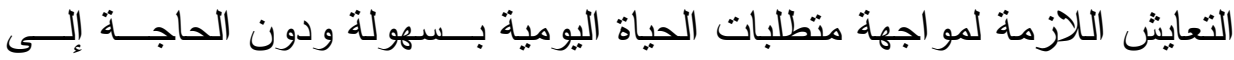

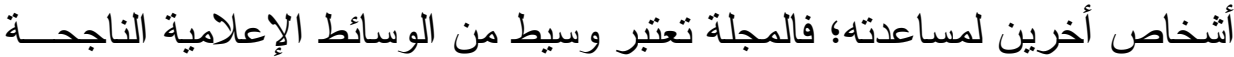


في تتمية معظم أغلب المفاهيم و المهار ات التي نرغب الطالبة المعلمة في تقديمها للطفل العادي و الطفل ذوي الاحتياجات الخاصة.

وتعتبر المجلات و الصحف الورقية مثل: الكتب التــي تـستعمل الكتابــة

و الرسم و الصورة، وتقدم للطفل المعلومات و المعسارف و المجــلات المــصورة

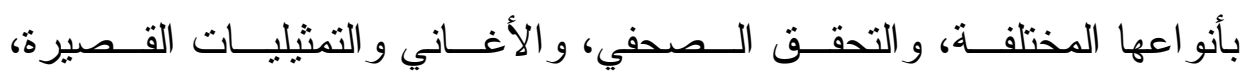

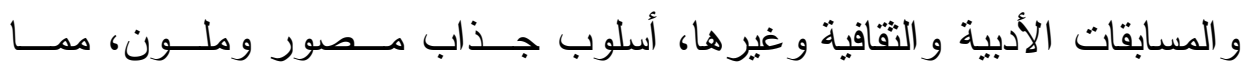

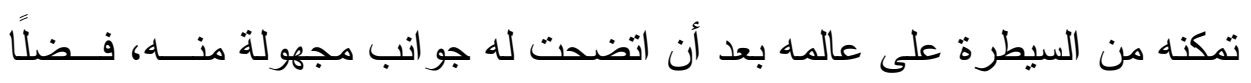

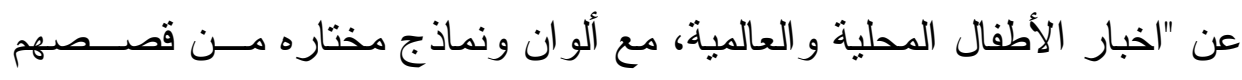

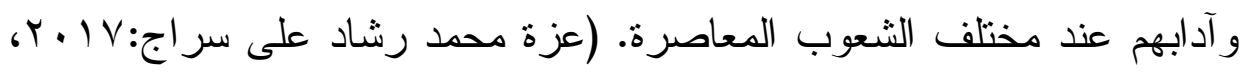

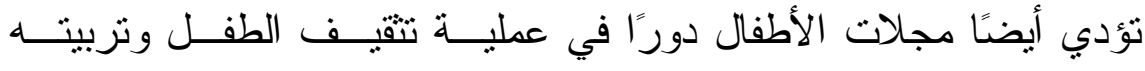

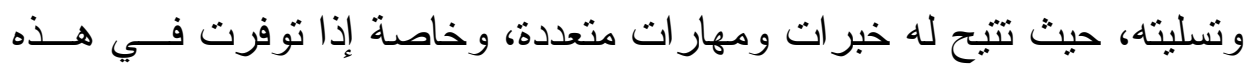

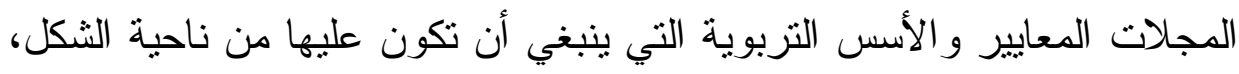

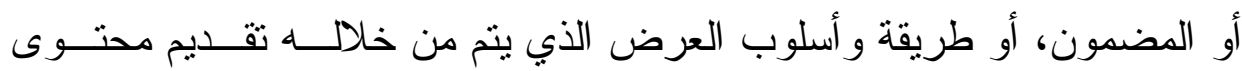

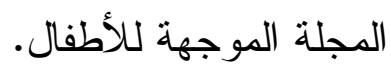

وعرف العالم العربي مجلات الأطفال في وقت مبكر ، فتعتبــر مجــلات

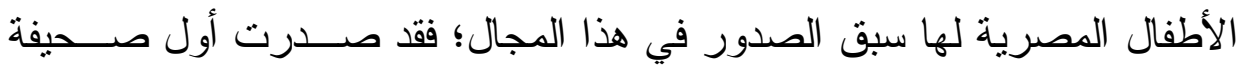

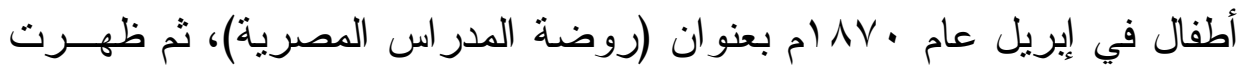

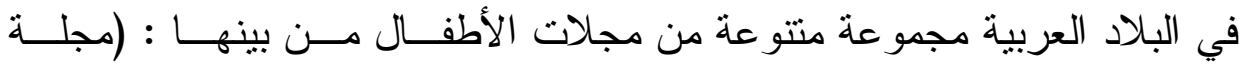

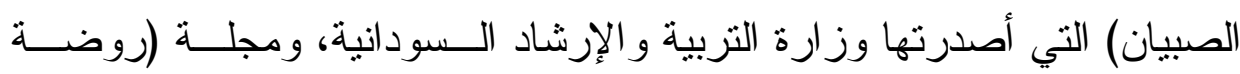

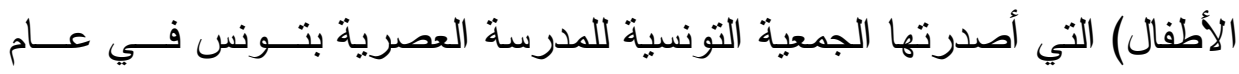


الr 90 ام، و أخذت المجلة الموجهة للأطفال تتمو في مختلف دول الوطن العربي.

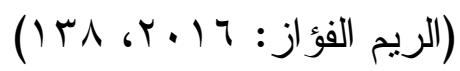

وتعرف مجلات الأطفال بأنها: مطبو عــة دوريــة تقــــم للطفــل الفنــــن

و المعارف و الآر اء و الصور المختلفة وتحيطه علمًا بالقضايا و الأحداث التي تدور

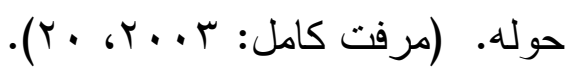

كما عرفت بأنها أداة مهمة من أدوات التثقيف و التزفيه تعتمد بشكل أساسي على الأنشطة المصورة باختلاف أنو اعها "فوتو غر افية - مرسومة - ســاخرة-

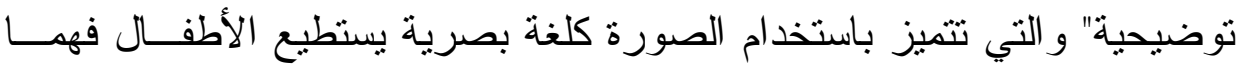

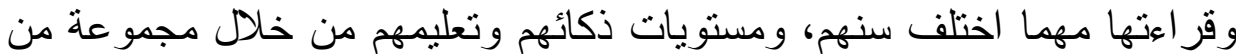
الأنشطة المصورة، و التي تعتمد على الاختلافات، ومعرفة الكلمـات، وعبــور متاهات بسيطة، و البازل، و التوصيل، و القصص المصورة، وغير ها من الأنشطة

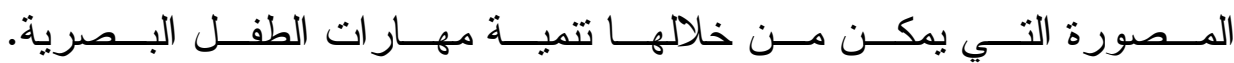

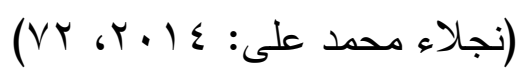

كما عرفتها (تغريد حمزة: 17 (1)، 10): هي مطبو عــة دوريسـة داخـلـ غلاف، عادة ما تقدم للطفل الفنون و الآداب و المعارف و العلوم المختلفة، وتحيطه

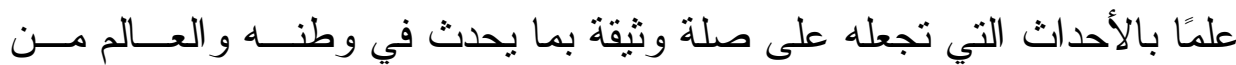

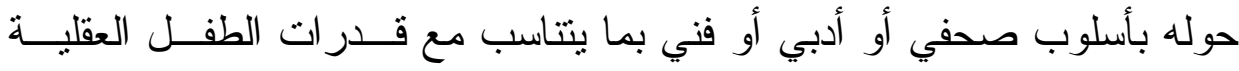

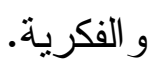

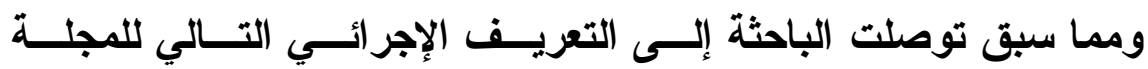

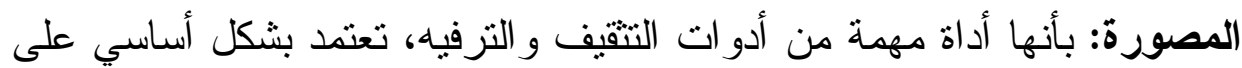

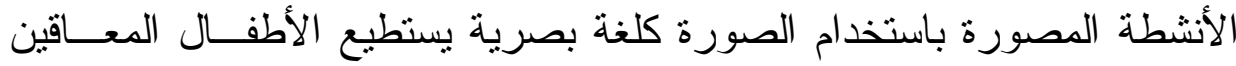


عقليًا القابلين للتعلم فهمها وقر اعتها مهما أختلف مستويات الــتعلم مــن خــلال مجموعة من الأنثطة المصورة والتي تعتمد على معرفــة الكلمــات، و عبــور

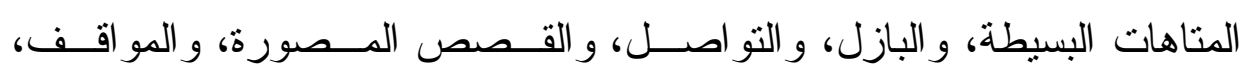

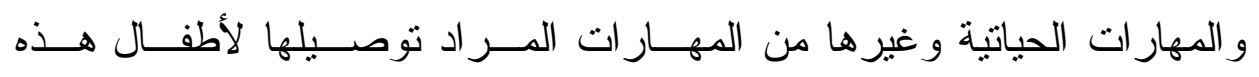
الفئة.

\section{خصائص مجلة الأطفال: 1}

وفيما يتعلق بالمو اصفات التعليمية الجيدة لمجلات الأطفال يشير "مــورو

ولينك" إلى أن هذه المجات يجب أن تشتمل على موضو عات حديثة ومتجــددة

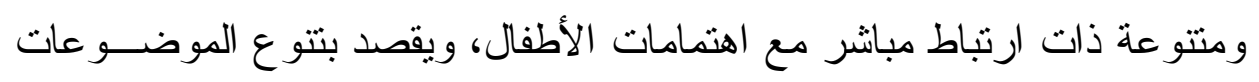

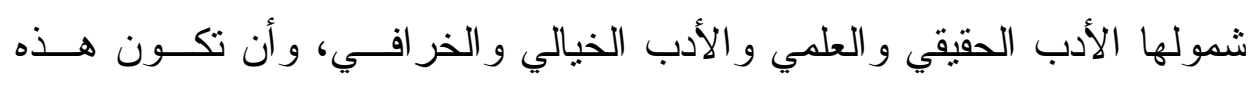

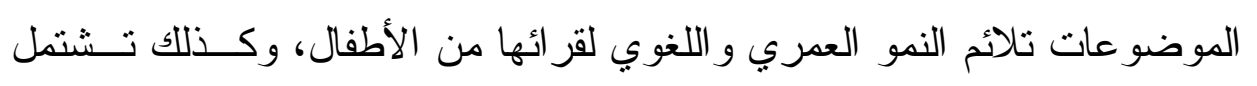

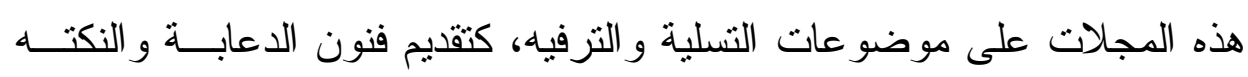
و المرح للأطفال، وكذلك تشتمل هذه الموضو عات على ألعــاب ذهنيـــة، مثــل الكلمات المتقاطعة.

وأوردت تغريا حمزة عددًا من الخصائص التي تنفرد بها مجلة الأطفــال تجعلها ذات تأثير قوي على الأطفال، منها: ا ـ تتمتع مجلة الطفل بجميع الخصائص التي تميز المادة المطبوعة، حيــث يستطيع الطفل أن يختار ما يروق له من مجموعة كبيرة من المجــاتلات اله

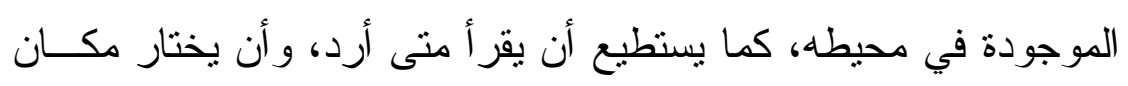

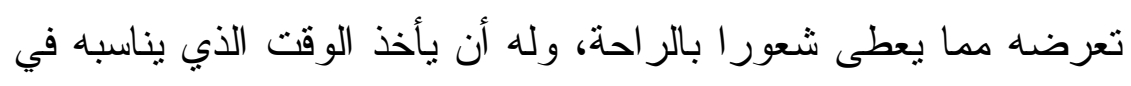


القر اءة حسب مقدرته اللغوية ومقدرته على الفهم، كما أن المادة المكتوبة تمثل جاذبية خاصة تتمثل في امتاع الذهن و إثارة الخيال. r. تتميز صحف الأطفال بالدورية أو الانتظام، وهذه الدوريــة أو الانتظــام تساعد على تكوين علاقة ثابتة بين الطفل ومجلته بحيث ينتظر ظهورها

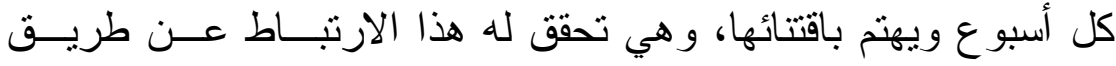

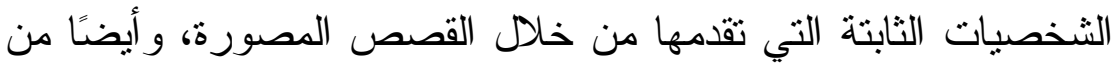

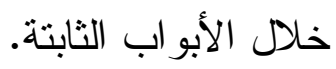

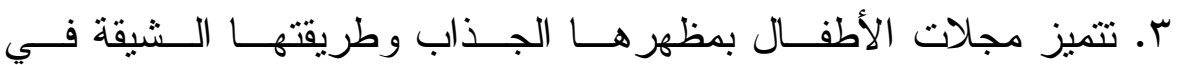

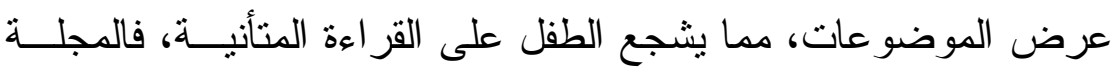

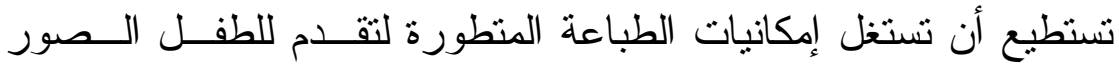

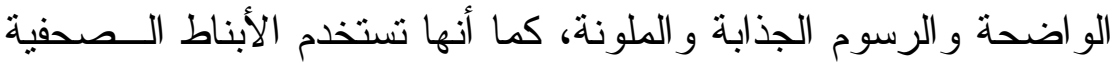
المختلفة و البر اويز و الإطار ات و العناوين مختلفة الاحجــام، بالإضــافة

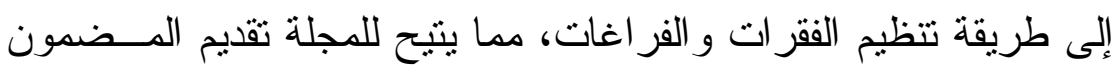

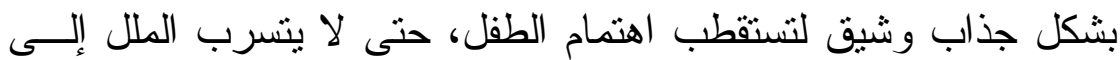
نفسه.

ع. تتميز صحف الأطفال باستعانتها بمختلف الفنون الأدبية و التشكيلية لتبدو

$$
\text { أمام الطفل مغرية وجذابه ويسيرة. }
$$

0. تتميز صحف الأطفال باحتو ائها على قدر معين وهادف من المعلومسـات

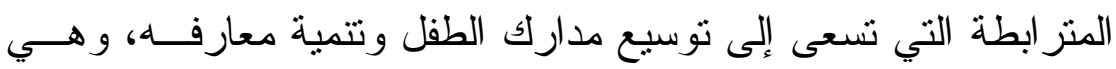

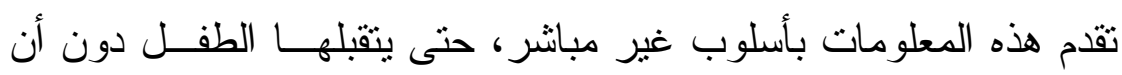
يشعر بالهدف التثقيفي أو التربوي منها. 
7. تتميز اللغة في صحف الأطفال بالبساطة و الوضوح، حتى تتناسـب مــع

حصيلة الطفل اللغوية، مع الحرص على وجود عدد قليل مــن الكلمـات

الجديدة بما يزيد من ثروة الطفل اللغوية.

V. يتميز الأسلوب الذي تتشر به الموضوعات المختلفة في مجلـــة الطفـلـل

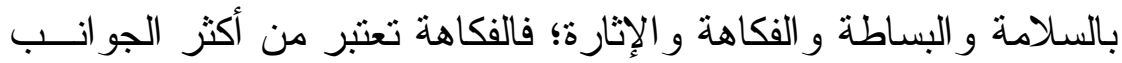

$$
\text { التي تجذب الطفل للمادة المكتوبة. }
$$

^. تتميز مجلة الطفل بالألو ان الز اهية التي تعطي المجلــة بريقِّــا يخطــف

أبصار القر اء الصغار ، ويجذبهم للموضو عات التي تضمها المجلة.

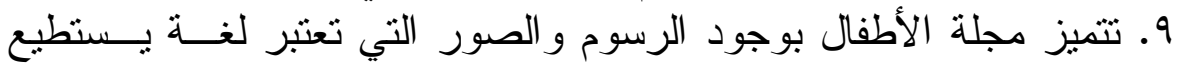

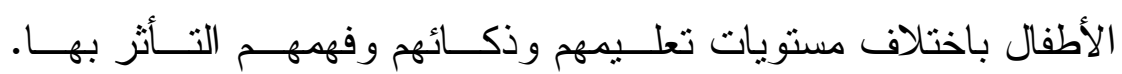

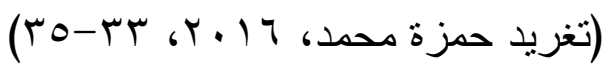

وتتمتع مجلات الأطفال بصفة عامة بعدد من السمات تجمع فيها بين عـدد

من الوسائل في وسيلة واحدة، وهي بذلك توفر للطفـلـل احتياجاتــه ومتطلباتــهـ

$$
\text { بأسلوب سهل وممتع وفي متتاول أغلبية الأطفال. }
$$

وتتميز مجلات الأطفال بصفة خاصة بالعديد من السمات والمميزات من أهمها: ا ـ استخدام الأسلوب التفاعلي من خلال تكنيك النص المتر ابط الذي يتضمن

$$
\text { نقاط داخل الموضوع. }
$$

r. اتاحة الفرصة في البحث و الاختيار و التصفح و التحاور مع الثخــصيات

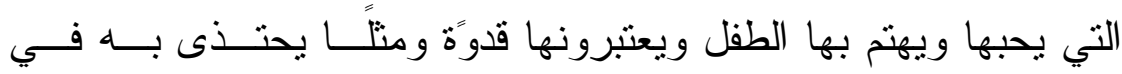

$$
\text { حاضر هم ومستقبلهم. }
$$

r. احاطة وربط الطفل بمصادر المعلومات. 
ع. تشكيل اتجاهات الطفل وصياغتها بما يتقق مع مستقبل المجتمع، و إدر الك أن الطفل اليوم هو الثناب غدا، وهو الذي يعتمد عليه الوطن في تيـسير

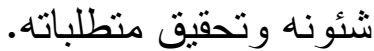

0. بث روح المسئولية والثعور بالولاء الوطني، واعتبار الوطن هو الكيان الذي يجب الدفاع عنه و الدحافظة على تر ابه ومقدر اته.

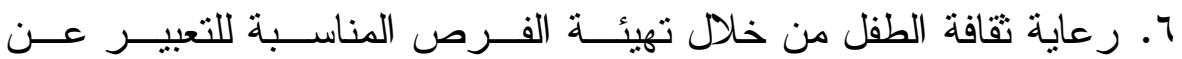

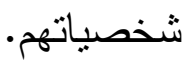

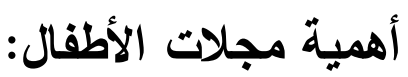

ترجع أهمية مجلات الأطفال إلى تمتعها بقدرة هائلة من التأثير في مجــال تربية الأطفال، و العمل على تزويدهم بالثقافة و المعرفة، وقد لخصت (هالة سعيد

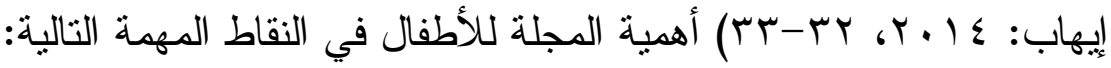

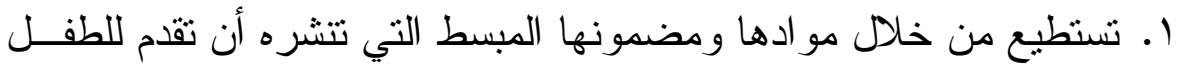
أصول المعارف من صحة و آداب و علوم مختلفة.

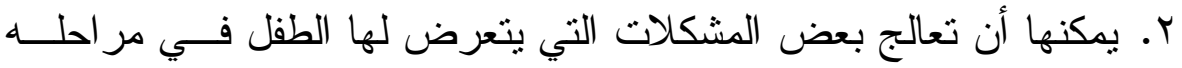

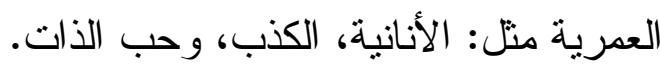

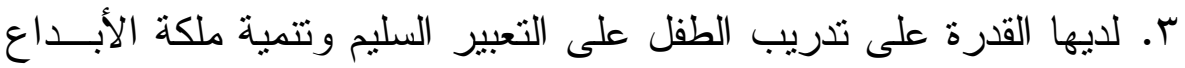
و الابتكار لديه، و النهوض بمو اهبه الدفيدة. ع. تتشط خيال الطفل وتغذية عقله بالجديد و المفيد لمرحلته العمرية. ه. تؤدي دورًا مهما للطفل عند إسهامها في تكوين وتـشكيل القـيم الدينيــة

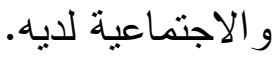
7. تعمل على توسيع دائرة معارف الطفل وتزويده بالخبر ات الهادفة. 
V. تؤدي دورًا مهما في رفع مستوى التعبير الثفهي و التحريري للطفل عن طريق الموضوعات القابلة للنقاش و الرد على البعض منها كتابة. A. لديها القدرة على الإجابة على تساؤلات الأطفال بشكل جيد. 9 ـ تشكل عقلية الطفل على الأفكار و المبادئ وتكسبه السلوك القويم. • ا ـ تؤدي دورًا مهما في التشنئة الاجتماعية و المحافظـــة علــى العــادات و التقاليد و القيم السائدة في مجتمعه.

\section{الشروط الواجب مر اعاتها في مجلاث الأطفال:}

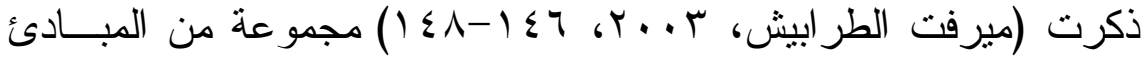
أمام القائم بالاتصـال (المحرر) تقف عند إعداده للمـــامين المقدمسـة لجمهــور الأطفال على مختلف مستوياتهم الاجتماعية و الفكرية و العمرية ومع هذا التبــاين أجمع الباحثون على عدد منها يصلح لأن يخاطب به الطفل وهي:

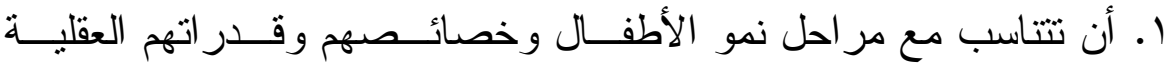
و ميولهم ناحية الأشياء. r. أن تتضمن ما يزيد من خبرات ومدارك الأطفال وتجاربهم و إثباع حبهم إلى المعرفة و الإجابة عن تساؤ لاتهم مهما كانت صعبة ومعقدة.

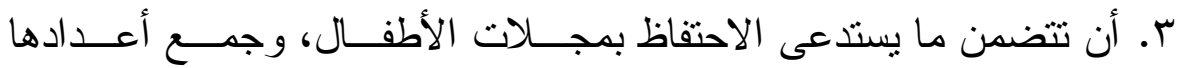
و الرجوع إليها عند الحاجة أو من وقت لآخر .

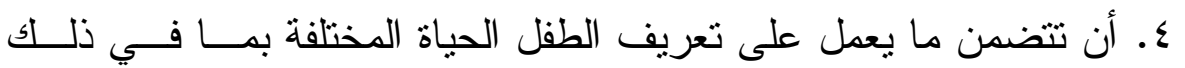
مفاهيم مبسطة لمختلف العلوم. ه. أن تقدم احتياجات الطفل الحقيقية وأن تتجنب أسلوب الـــوعظ و الإرشــاد و التلقين الذي يقتل الابداع و الفكر . 
T. ألا تضحي بالاعتبار ات التربوية و الثقافية في سبيل البحث عن مزيد من

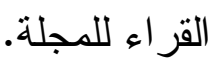

V. أن تقدم المواد المترجمة بعناية ودقة حتى لا يتشتت فكر الطفل بين القيم

الموجودة بالمجتمع و القيم الو افدة إليها.

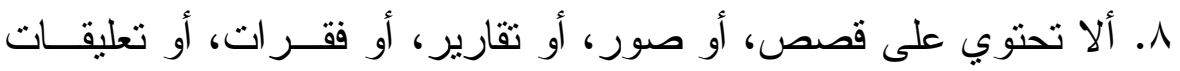

تتضمن الإشادة بأعمال اللصوصية و الخائنين للأوطان و الأصدقاء.

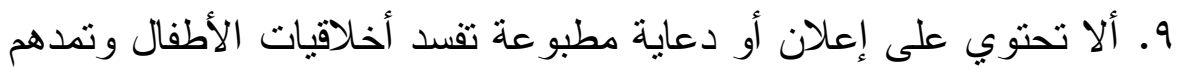

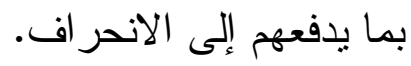

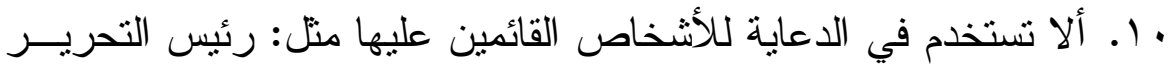

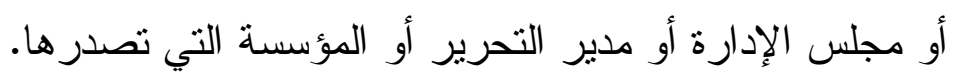

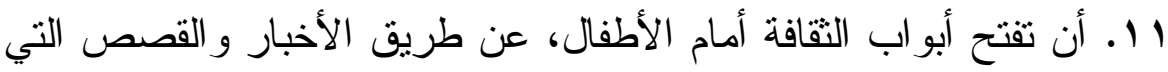

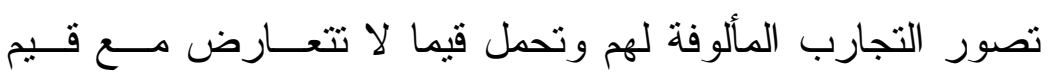
المجتمع السائدة.

خطوات تصميم المجلة المصورة للأطفال المعاقين عقليًا (القــابلين

أولا: الفكرة التي تصمم عليها المجلة:

$$
\text { 1. بكون لها هدف و اضح. }
$$

r. تزيد من فاعلية الاتصال بين المعلمة و الطفل.

T. بحتوي مضمونها على الفكرة.

ع. ـ تهدف إلى تتمية المهار ات. 


$$
\begin{aligned}
& \text { 0. تهدف إلى زيادة المعارف. } \\
& \text { 7. تؤدي إلى تتمية الابداع و الخيال. } \\
& \text { V. تعمل على تعديل السلوكيات و القيم. } \\
& \text { ^. تهدف إلى تتمية الذوق الفني. } \\
& 9 \text { ـ إثارة حب الاستطلاع و الانفتاح على العالم. } \\
& \text { • } 1 \text { ـ تهدف إلى التسلية و الترفيه. } \\
& \text { ثانيا: القطع: "يقصد به أبعاد المجلة" } \\
& \text { 1. اختيار التتاسب بين الطول و العرض و السمك. } \\
& \text { r. شكل المجلة مربعا أو مستطيلا. } \\
& \text { r. شكل المجلة أفقيا أو رأسيا. }
\end{aligned}
$$

ع. أن نتتاسب مع الأثكال المعاصرة و المستحدثة. هـ استخدام خامات من القماش و البلاستيك المحشو بالإسفنج. ثالثا: الغلاف الخارجي للمجلة: ا • يتكون من وجهين أمامي وخلفي. r. الوجه الأمامي هي صورة و اضحة جميلة. r. تشغل الصورة في الوجه الأمامي \%V0\%. ع. العنوان يكون على الوجه الأمامي و اضح ومقروء. 
0. الوجه الخلفي يشتمل على بيانات السلسلة. 7 . يكتب على الوجه الخلفي سنة الطبع ومكانه و السعر ورقم الإيداع. V. لون و احد للخلفية على الوجهين. ^. صورة على الوجه الأمامي وصغيرة على الوجه الخلفي.

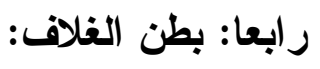

ا ـ تصميم مشهد طبيعي وبه طفل. r. تصميم صورة من داخل المجلة. r. تصميم إطار يكتب فيه اسم الطفل وفصله. ع. استخدمت الألو ان بجانب الأبيض و الأسود. 0. تصميم جو يهئ الطفل للاخول إلى المجلة. 7. تصميم بداية المجلة. V l. تصميم زخرفي يتتاسب وموضوع المجلة. A. تصميم كاريكاتير محبب للطفل. خامسا: صفحة العنوان الاخلي: ا ـ تشتمل على عنوان المجلة بجانبي الصورة الرئيسية للمجلة. r - بستخدم اللون غي تصميمها. ب. يكتب بها اسم الرسام و المــصور و الناثـــر و الــشعار ومكــان وســنة الطبع. 


$$
\begin{aligned}
& \text { ع. يحدد رقم الطبعة (أولى - الثانية - الثالثة -....إخخ). } \\
& \text { 0. تفوق هذه الصفحة الغلاف في جمالها. }
\end{aligned}
$$

7 ـ يستخدم المصمم الألو ان و الخطوط و التعبير و الملمس بكفاءة.

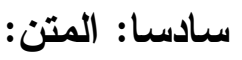

ا ـ تكتب سطور المتن بسمك مختلف.

$$
\text { r ז. يختلف سمك الكتابة في الثكل و النوع و الحجم. }
$$

7 . . عندما يطبع المتن على خلفية قائمة يفرغ بحيث يظهر بلون الورق.

$$
\text { V. استخدام حروف الاستهلال في بداية الفقرات بالمجلة. }
$$

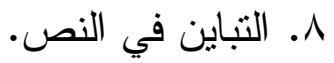

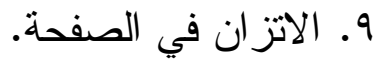

• ا ـ يشغل نسبة . r\% من الصفحة.

$$
\text { سابعا: الرسوم والصور في المجلة. }
$$

$$
\text { ا ـ البساطة و الوضوح في الصورة المرسومة. }
$$

r. نسبة مساحة الرسوم إلى المساحة الكلية للصفحة. 


$$
\begin{aligned}
& \text { r. عدم استخدام الصور الفوتوغر افية. } \\
& \text { ع. قرب الصورة المرسومة من الواقع. } \\
& \text { 0. تتاسب الصورة مع الفكرة التي وضعت لها } \\
& 7 \text { ـ. يجب أن تخلو الصورة من التفاصيل الكثيرة. } \\
& \text { V. الصورة توضح النص المكتوب. }
\end{aligned}
$$

^. مساحة الصورة كبيرة بما يساعد على إدر الك تفاصيلها.

$$
\text { 9. التتاسب بين المادة المنشورة و الصورة. }
$$$$
\text { • . . تساعد على التشويق وتأكيد الهدف و المضمون. }
$$

ثامنا: الألوان المستخدمة في مجلات الأطفال:

$$
\text { ا ـ استخدام الألوان الأساسية. }
$$

r. وجود تتاسق بين الألو ان المستخدمة.

$$
\text { r. أن تكون الألو ان ز اهية ودرجتها فاتحة. }
$$

ع. التنوع بين استخدام الألوان.

$$
\text { 0. مساحات الألو ان مفصولة عن بعضها. }
$$

$$
\text { 7. استخدام لون و احد في كل مساحة. }
$$

V. المزج بين الألوان الأساسية في الرسوم.

^ـ استخدام الألو ان المختلفـــة كــالجو اش، و الألــــوان المائيـــة، و الخــشب، و الأكليريك. 


$$
\text { ت } 9 \text { ـ استخدام الكو لاج و ألوان الزيت. التجسيم: }
$$

ا ـ استخدام المصمح للمنظور •

r. استخدام المصمم التظليل.

r. استخدام المصمم التعبير عن القريب و البعيد.

$$
\text { ـ. استخدام الخطوط و الألوان في التجسيم. }
$$

0. استخدام الألوان الباردة في الخلفية ليعطي إحساس بالعمق.

7 ـ استخدام الألوان الساخنة لتعبر عن مغلقة دافئة.

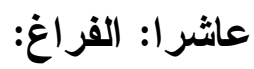

$$
\text { r ا . يساعد على قر اعة النص. }
$$

r. بعطى قدرة على التباين بين عناصر الصفحة.

ع. تساعد على راحة عين الطفل.

$$
\text { إجر اعات البحث }
$$

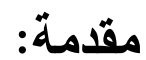

يهدف هذا الفصل إلى عرض المنهج الذي اتبعته الباحثة في بناء البرنامج

التدريبي للطالبة المعلمة لتصميم المجلة المـصورة اللازمسـة لتقــديم مهـار ات

التعايث للأطفال المعاقين عقليًا (القابلين للتعلم). 
ومن ثم يتضمن هذا الفصل عرضنًا للإجر اءات التي تم القيام بها في هــــا

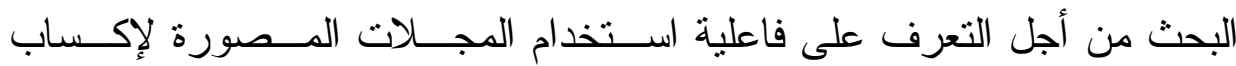
الطالبات المعلمات مهار ات تصميم المجلات المصورة لتقديم مهار ات التعسايش

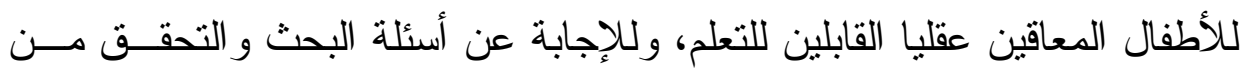
صحة الفروض تم إعداد الأدوات على النحو التالي: ( ) استبانة تحديد مهار ات التعايش لدى الأطفال المعـاقين عقليًا القـابلين للتعلم. r) مقياس تصميم مجلات الأطفال للطالبة المعلمة لمعرفة مدى تمكنها مــن تصميم المجلات للأطفال المعاقين عقليًا لتتمية مهار ات التعايش لديهم. r) بطاقة ملاحظة أداء الطالبة المعلمة في تصميم مجلات الأطفال.

$$
\begin{aligned}
& \text { وفيما يلي نتتاول أدو ات البحث بالتقصيل. } \\
& \text { أولا: أدوات ومواد البحث: }
\end{aligned}
$$

استبانة مهارات التعايش لدى الأطفال المعاقين عقليا القابلين للتعلم: للإجابة على السؤال الأول من أسئلة البحث الذي نص على: ما مهـارات

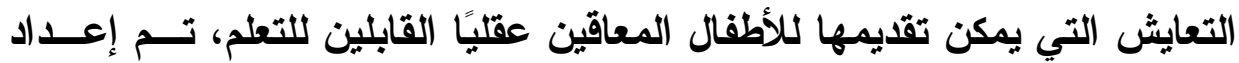
الاستبانة وفقا للإجر اءات التالية:

$$
\begin{aligned}
& \text { (1) تحديد الهذف من إعداد الاستبانة. } \\
& \text { r إعداد الصورة الأولية للاستبانة. } \\
& \text { r) عرض الاسنبانة على السادة المحكمين. }
\end{aligned}
$$

§) التوصل لقائمة بمهار ات التعايش لدى الأطفال المعاقين عقليــا القـابلين

$$
\text { للتعلم. }
$$




$$
\text { ويمكن توضيح الإجر اعات بالتفصيل فيما يلي: الإجابة على السؤال. }
$$

إن الهدف من الاستبانة هو تحديد مهار ات التعايش لدى الأطفال المعـاقين

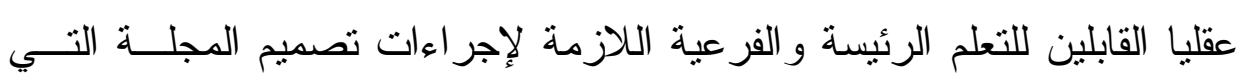

ستقوم بتخطيطها وتتفيذها الطالبة المعلمة.

$$
\text { r) إعداد الصورة الأولية للاستبانة: }
$$

تم إعداد استبانة أولية بمهار ات التعايش لدى الأطفــال المعــاقين عقليــا

$$
\text { القابلين للتعلم من خلا: }
$$

- الاطلاع على الأدبيات و البحوث و الدر اسات السابقة المتعلقــة بمهــار ات

$$
\text { التعايش لدى الأطفال المعاقين عقليا القابلين للتعلم. }
$$

• الاطلاع على قائمة المهار ات الواجب تتميتها لدى الأطفال المعاقين عقليا القابلين للتعلم ومعرفة خصائصهح وقدر اتهم من الدر اسات السابقة.

من خلال ما سبق تم إعداد استبانة أولية بمهار ات التعايش لدى الأطفــال المعاقين عقليا القابلين للتعلم لنتفيذ وتصميم مجلات تتاسب احتياجـاتهم وتتمـي لديهم تلك المهار ات؛ وقد اثتنملت القائمة على:

$$
\text { ثلاث مهار ات رئيسة كالتالي: }
$$

- - أولا: المهار ات الذاتية للأطفال المعاقين عقليا القابلين للتعلم. - ثاتيا: مهار ات التعامل مع الآخرين للأطفال المعاقين عقليــا القــابلين

$$
\text { للتعلم. }
$$


- ـ ثالثا: مهار ات مشاركة الأخرين و التعاطف معهم للأطفــال المعــين

عقليا القابلين للتعلم. - مهن.

$$
\begin{aligned}
& \text { • • ( (9) مهارة فرعية في صورتها الأولية. } \\
& \text { ץ)عرض الاستبانة على السادة المحكمين. }
\end{aligned}
$$

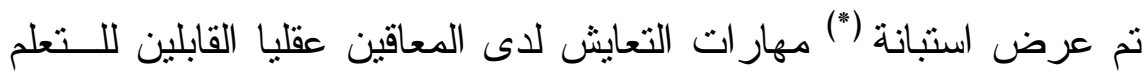

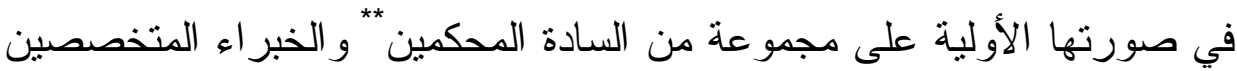
في مجال العلوم الأساسية وعلم نفس الطفل؛ لإبداء آرائهم وخبر اتهم حول أهمية

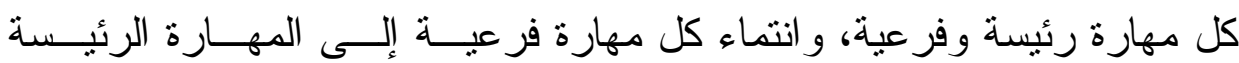
المحددة، مع إضافة أو تعديل ما يرونه مناسبا. ؛) التوصل لقائمة بمهارات التعايش لاى الأطفال المعاقين عقليًا: بعد إجر اء ما أبداه السادة المحكمون من تعديلات على اسـتنبانة مهــار ات

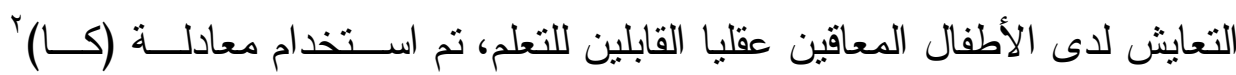
لتحديد المهار ات الفرعية لههار ات التعايش التي يمكن تتميتهـــا لـــى الأطفــال المعاقين عقلبا القابلين للتعلم علما بأن:

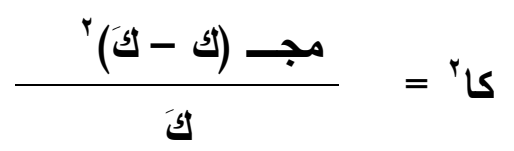

(عبد الهادي عبده، فاروق عثمان، +. . r: 100)

$$
\text { حيث إن كَ = التكر ار الملاحظ. }
$$

• ملحق (r) استبانة مهارات التعايش لاى الأطفال المعاقين عقليا. • ملحق (1) أسماء السادة المحكمين. 


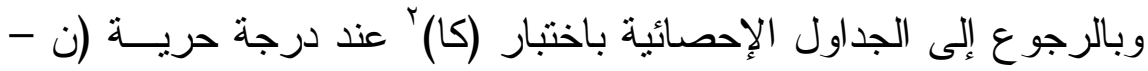

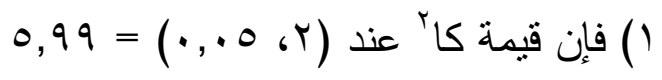

و أصبحت القائمة في صورتها النهائية وتنشمل على:

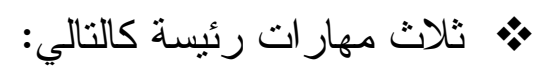

- - أولا: المهار ات الذانية للأطفال المعاقين عقليا القابلين للتعلم.

- ثاتيا: مهار ات التعامل مع الآخرين للأطفال المعاقين عقليــا القـابلين

للتعلم.

- ثالثا: مهار ات مشاركة الأخرين و التعاطف معهم للأطفــال المعـاقين

عقليا القابلين للتعلم. - مهان.

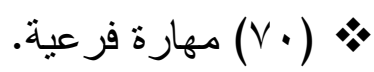

قائمة معايير ومؤشرات مهارات التعايش لاى الأطفال المعاقين عقليا القــابلين

تم استخلاص مجموعة من المؤشر ات و المعايير و التي يمكن تضمينها في تصميم البرنامج التدريبي بما يساعد الطالبة المعلمة علـى تــصميم المجــلات للأطفال المعاقين عقليا القابلين للتعلم، وتم اثتنقاق القائمة مـنـن خــلال اســنبانة

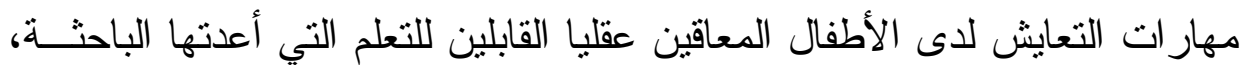
و اعتمدت الباحثة في استخلاص هذه القائمة على الآتي: 1) الهـف من القائمة:

تهدف القائمة بشكل أساسي إلى تحديد بعض مهار ات التعايش لدى الطفــلـ المعاق عقليا القابل للتعلم و التي ستستعين بها الطالبة المعلمة في تصميم المجلات

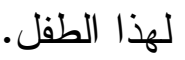


أ- مصادر اشتقاق قائمة المؤشر ات والمعايير:

أمكن التوصل للقائمة من خلال المصادر الآتية:

- تحكيم الاستبانة ووضعها في صورتها النهائية.

• الاطلاع على الدر اسات السابقة في نفس المجال.

" الاطلاع على قائمة المهار ات الواجب تتميتها لدى الأطفال المعاقين عقليا

القابلين للتعلم ومعرفة خصائصهم وقدر اتهم من الدر اسات السابقة.

\section{ب -صياغة بنود القائمة:}

بعد جمع ما تم الحصول عليه من مؤشرات ومعايير، تم مر اعاة الآتي في تحديد قائمة المؤشر ات و المعايير في صورتها الأولية:

- - صياغة العبار ات التي تمنل مهار ات التعايش بوضوح و التي تم تحديــدها

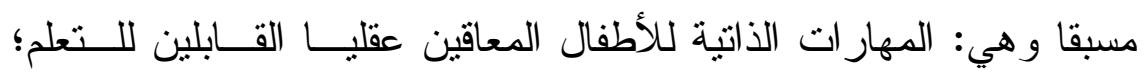

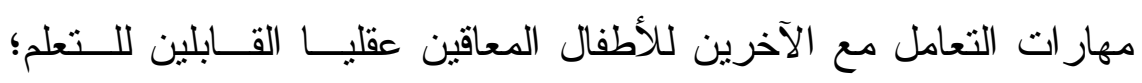
مهار ات مشاركة الأخرين و التعاطف معهم للأطفال المعاقين عقليا القابلين للتعلم، بحيث لا يجد القارىئصعوبة في فهم الأفكار المتضمنة بها. - - صياغة العبار ات التي تمنل مهار ات التعايش في صورة مجموعــة مــن الأهداف توضح المهام المختلفة التي ينبغي على الطالبة المعلمة أن تكون قادرة على تتفيذها في المجلات المعدة للأطفال المعاقين عقليــا القــابلين للتعلم. - أن تشمل القائمة على المعايير و المؤشر ات في ضوء ما يجب أن يكــون، وليس في ضو ء ما هو كائن من أوضاع. 
الاقتصار على أهم وأبرز ثلات مهار ات للتعايش، و التي بمكن تتميتها من

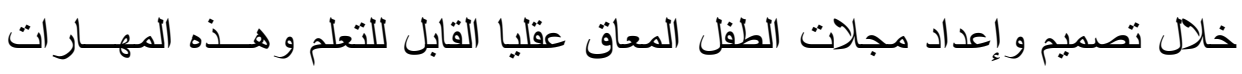

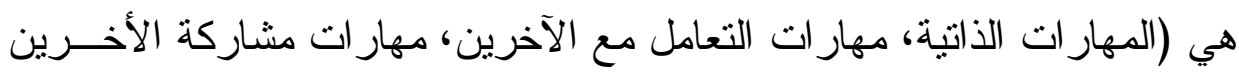

$$
\text { و التعاطف معهم). }
$$

ج-القائمة في صورتها النهائية:

أو لا: المهارات الذاتية للأطفال المعاقين عقليا القابلين للتعلم:

وتشمل الرئيسة المهار ات الفرعية الآتية: ا ـ بهتم بنظافة أسنانه

r r بحافظ على ترتيب ملابسه.

r. بر اعى النظافة الثخصية.

ع. يرندي جوربه بنفسه ويربط حذائه بنفسه.

ه. يهنم بنظافة شعره و أظافره.

7. يعرف أجز اء جسمه " اللسان - الرموش-الأسنان - الأظافر"

V. يفرق بين الملابس الصيفية و الشتوية.

$$
\text { A. يسمى ويعد أدو ات المائدة. }
$$

9. يستطيع إقفال أزر ار قميصه بنفسه.

• 1. يفرق بين ملابس الخروج وملابس المنزل.

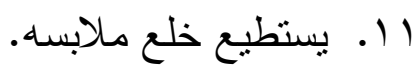

r ا. . يغسل وجهه بالماء و الصابون.

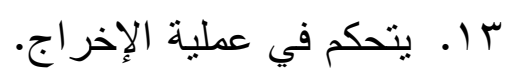

ـ ا. يستعمل المرحاض بدون مساعده.

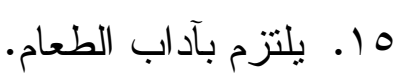


7 ا ـ يضع المناديل في سلة المهماتات بعد استخدامها.

IV . . يجفف جسمه بعد الاستحمام بمنشفته الخاصة.

1 1. غسل بده جيدا بالماء و الصابون.

9 1 . شرب السو ائل بدون مساعدة الأخرين.

•r. . غسل الخضروات و الفاكهة جيدا قبل تتاولها.

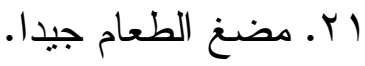

r r. تجنب التنفس في الإناء.

rr. يعرف الوقت باستخدام الساعة.

ع r . يرتب سريره بعد الاستيقاظ.

0. يستطيع استخدام الهاتف المحمول.

Tr. . بضع مالابسه على الثماعة.

ثاتيا: مهارات التعامل مع الآخرين للأطفال المعاقين عقليا القابلين للتعلم:

ا ـ يستمع إلى تعليمات المعلمة وينفذها.

r. أن يسأل بأدب دون مقاطعة الأخرين.

r. يستخدم عبار ات (من فضلك - شكر ا) أثناء الحديث.

ع. يطرق الباب قبل دخول الغرفة.

ه. يستأذن قبل الانصر اف.

7. يتحدث بلباقة أمام الغرباء.

V. يتدرب للرد على الهاتف.

^. يفرق بين المناسبات (الفرح-الحزن)

9. يعبر عن الفرح بكلام جميل.

• ـ . يستخدم العبار ات المناسبة المعبرة عن الأحزان. 


$$
\begin{aligned}
& \text { 11 } 11 \text {. يتعامل مع زملائه بحب. } \\
& \text { r ا ـ ـ ينفذ تعليمات و الدته. } \\
& \text { ז ا. ـ يتقهم قو اعد اللعب مع زملائه. } \\
& \text { ع ا ـ . يتعرف أن في كل مبار اة فائز . ل } \\
& \text { 1 ا ـ .ير اعي الهدوء أثناء فترة الر احة. } \\
& \text { ا ا . يتحمل المسؤولية أثناء الخروج. } \\
& \text { IV } \\
& \text { 1 ا . يكون علاقات مع الأطفال الأخرين (الأطفال العاديين). } \\
& 9 \text { 1 . . يمارس الرياضة مع زملائه. }
\end{aligned}
$$

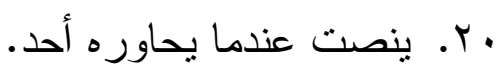

$$
\begin{aligned}
& \text { ו r. يستخدم جملا مفيدة عند الحديث. } \\
& \text { r. بطر ح الأسئلة على الأخرين بسهولة. } \\
& \text { سr. يعرف المهن المختلفة وكيفية التعامل معها. } \\
& \text { ع r. يتقبل النقد البسيط من الأخرين. } \\
& \text { هr. يتحكم في مشاعره وردود أفعاله. } \\
& \text { דr. . ينقل رسالة شفوية مع حرية الحركة. }
\end{aligned}
$$

ثالثا: مهار ات مشاركة الأخرين والتعاطف معهم للأطفال المعاقين عقليا القابلين

$$
\text { للتعلم: }
$$$$
\text { ا ـ ب بساعد و الدته في إعداد المائدة. }
$$$$
\text { r. بشـارك في تتظيف حجرته. }
$$

r. ينظف حديقة المدرسة مع زملائه.

$$
\text { ع. يساعد زمالائه في تتاول الطعام. }
$$




$$
\text { 4. } 1 \text { ـ. يشارك في المناسبات و الأعياد. }
$$

V . يحاول فهم مشاكل الأخرين ويساعد في حلها.

1. يهتم بمصلحة الأرخين ويقدمها على مصالحه الثخصية. 9. يشعر بزملائه في الفرح و الحزن ويظهر ذللك على ملامح وجهاهـ. • ا. يحاول أن يصلح بين زملائه المتخاصمين

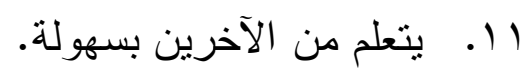

r ا. بيثق بنفسه في التعامل مع الآخرين.

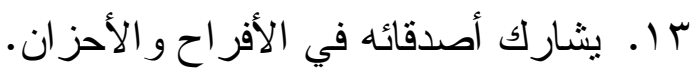
ـ ا. يطلب مساعدة الآخرين عندما يحتاج لذلك.

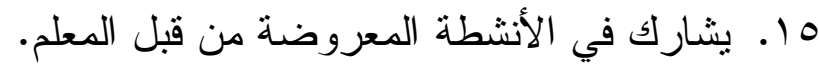
17 ا. يعبر عن مشاعره الإيجابية والسلبية. V V ا . ير اعى التقاليد الاجتماعية في المناسبات العامة.

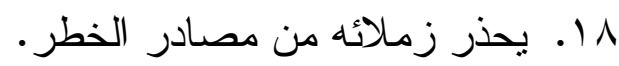
وبذلك تكون تمت الإجابة على السؤ ال الأول من مشكلة البحــث وهـــ : ما مهارات التعايش التي يمكن تقديمها للأطفــال المعــاقين عقليًّا القـابلين للتعلم؟

$$
\text { مقياس مهار ات التعايش: }
$$

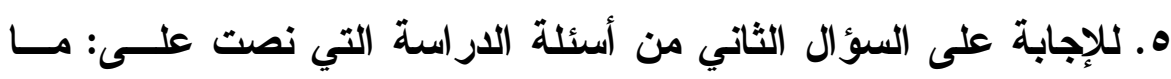

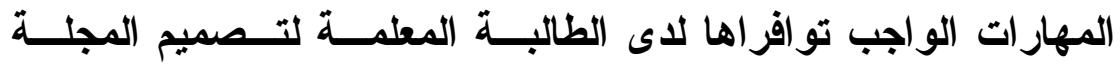

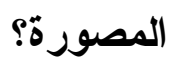


وللكثف عن أهم مهار ات تصميم مجلات الأطفال المعاقين عقلبا القـابلين

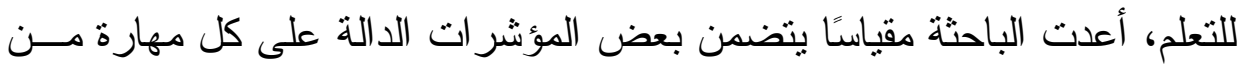
مهار ات التصميم العشرة، وذلك في ضوء در اسات وبحسـوث تــصميم مجــلات الأطفال في مجال أدب الطفل و الأطفال المعاقين عقليا. وقد مر إعداد هذا الدقياس بالخطوات التالية: ( ) تحديد الهذف من المقياس:

يهذف هذا المقياس إلى الكثثف عن مهار ات تـصميم مجــلات الأطفــال

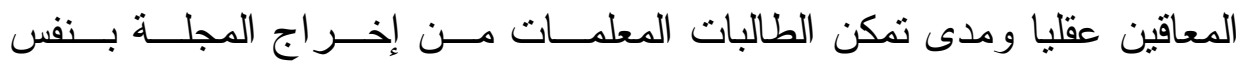

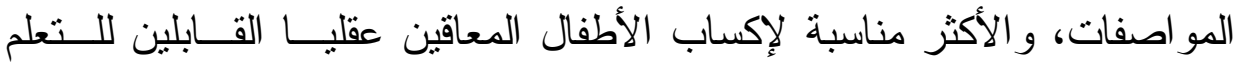

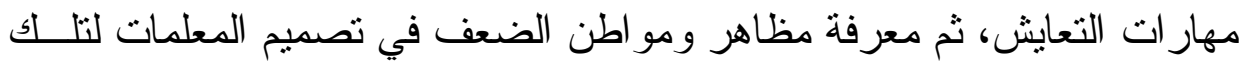
المجلة حتى يتتسى علاجها وتقدميها في أفضل صورة تر اعي خصائص هـؤه لاء

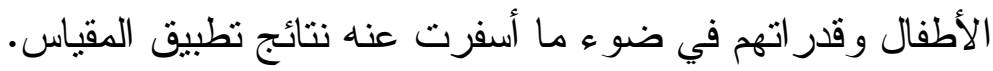
r) إعداد الصورة الأولية للمقياس:

تم صياغة المؤشر ات الدالة على مهار ات تصميم مجلات الأطفال المعاقين

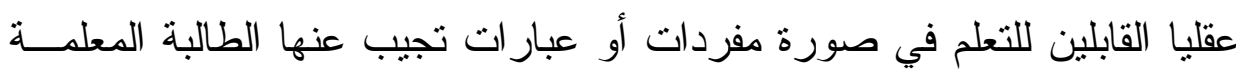

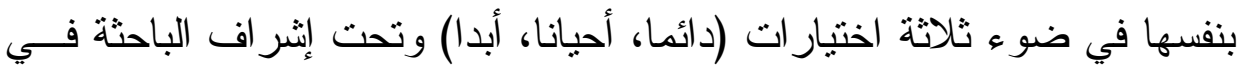

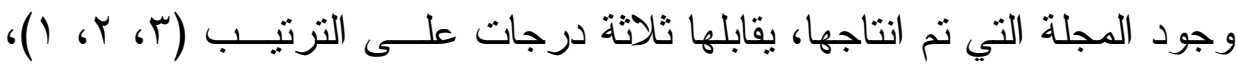

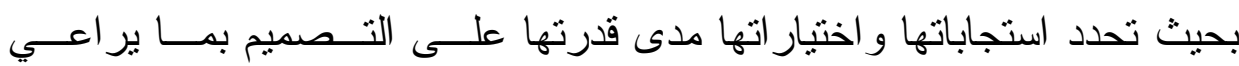

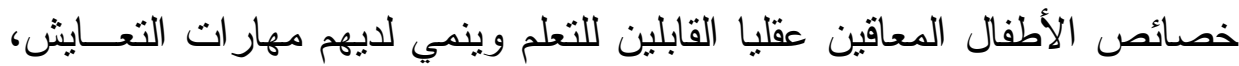
وتضمن المقياس في صورته الأولية على (YT) عبارة موزعة بالتساوي علىى 
مهار ات تصميم المجلة العشرة، بمتوسط (^) عبار ات لكل مهارة تقريبا، وبذلك أصبحت الصورة الأولية للمقياس جاهزة للعرض على السادة الدحكمين.

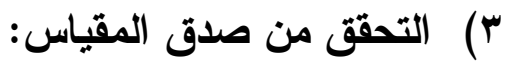

تم عرض المقياس في صورته الأولية على مجموعة من التنصصين في

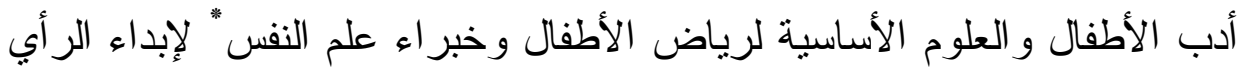
في مدى ملاءمة مفردات المقياس للهدف الذي صمح من أجله، وصـــتها مسن الإنس حيث الصياغة، ومدى شمولها لجميع مؤشرات تصميم مجلات الأطفال المعاقين

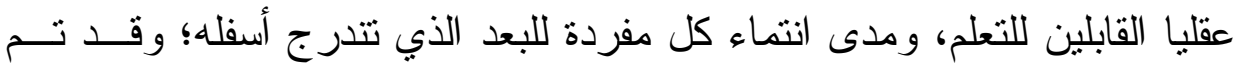
إجر اء التعديلات التي اقترحها السادة المحكمين من حيث حذف بعض المفردات أو إضافة البعض الآخر أو تعديل الصياغة اللغوية والتربوية لها؛ ومن ثم أصبح المقياس محتويا على (• آ) مفردة.

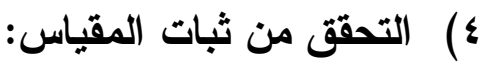

قامت الباحثة بتطبيق المقياس على مجموعة استطلاعية (غير مجموعــة

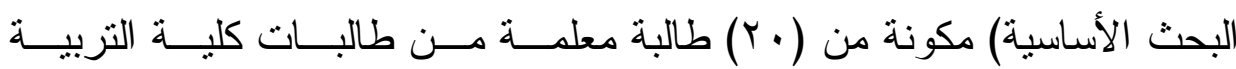

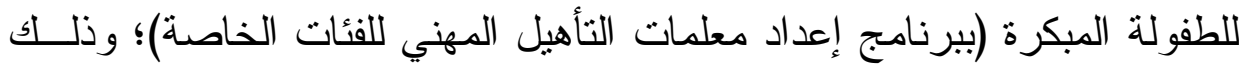

أ- حساب صدق المقياس.

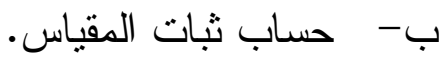
ج- حساب زمن المقياس، وفيما يلي تفصيل ذلك: • ملدق ( ): قائمة بأسماء السادة الدحكين على أدوات البحث. 
أ- - حساب الصدق للمقياس "صدق الاتساق الداخلي" "التجانس الاخلي":

تم حساب الصدق للمقياس، بحساب معامل الارتباط بين درجات عبــار ات

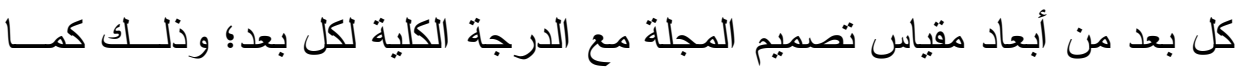

$$
\text { يوضحه جدول (1): (1) - (1) }
$$

\section{جدول (1)}

معاملات الارتباط بين درجة كل عبارة من عبارات المقياس مع الارجة الكلية لكل بعد

\begin{tabular}{|c|c|c|c|c|c|c|c|}
\hline 1 & • & $\varepsilon$ & $r$ & r & 1 & العبارة & \multirow{2}{*}{ الفكرة } \\
\hline$* *, 79 \wedge$ & $* *$, , & 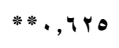 & **, or & $* *, \uparrow \wedge$. & $* *, \diamond \vee$. & معامل الارتباط & \\
\hline ir & 11 & 1. & 9 & $\wedge$ & $v$ & العبارة & \multirow{2}{*}{ القطع } \\
\hline$* *$, r & $* *, 711$ & $* *, \circ \sim q$ & $*,, \leq 4$ & 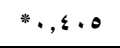 & ** • , Y & معامل الارتباط & \\
\hline 11 & iv & 14 & 10 & $1 \varepsilon$ & ir & العبارة & \multirow{2}{*}{ الغارجي } \\
\hline$* *, \diamond \vee$. & r**, r ז & $* *$, or & $* *, \wedge 1 \leq$ & $* \cdot, \varepsilon, 4$ & $* * *$, * & معامل الارتباط & \\
\hline$r \varepsilon$ & r & rr & rr & $r$. & 19 & العبارة & \multirow{2}{*}{ بطن الغلاف } \\
\hline$* * *, \leqslant \vee$. & $* *, \neg \wedge \vee$ & $* *, \circ \vee$. & $* *, 09$. & $* *, \uparrow \circ 9$ & $* \cdot,, \leq \leqslant 9$ & معامل الارتباط & \\
\hline$r$. & rq & rA & $r V$ & ז & ro & العبارة & \multirow{2}{*}{ صفحة العنوان } \\
\hline 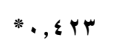 & *, •, & $*, r q \vee$ & 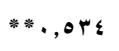 & $*,, \leqslant 1$. & $* *, V Y r$ & معامل الارتباط & \\
\hline ry & ro & $r \varepsilon$ & rr & rr & $\mu$ & العبارة & \multirow{2}{*}{ المتن } \\
\hline$* *, \cdot, \vee \diamond \wedge$ & $* *, \vee v \cdot l$ & ***, ฯ \ & $* *, 4$. & 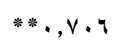 & $*, r q \Delta$ & معامل الارتباط & \\
\hline$\varepsilon r$ & « & $\varepsilon$. & rq & rA & $r v$ & العبارة & \multirow{2}{*}{ والصور } \\
\hline$* *, \cdots$. & $*, r v o$ & 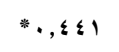 & 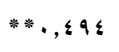 & $* *, ., \wedge$ & r & معامل الارتباط & \\
\hline$\varepsilon \wedge$ & $\varepsilon v$ & $\leqslant 4$ & $\leq 0$ & $\varepsilon$ & \& & العبارة & \multirow{2}{*}{ الألوان } \\
\hline$* * *, 79 \leq$ & 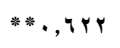 & $*$ *, $\{4$ & ***, v r r & $* *, V r_{1}$ & $*$, , $\leqslant 4$ & معامل الارتباط & \\
\hline 0 \& & or & Or & 01 & ○. & $\leq 9$ & العبارة & \multirow{2}{*}{ التجسيم } \\
\hline$*, \cdot \varepsilon \cdot r$ & 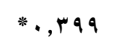 & צוזו, • "* & $* * *, £ \wedge \diamond$ & 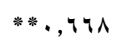 & $* *, 001$ & معامل الارتباط & \\
\hline$\checkmark$. & .9 & $0 \wedge$ & ov & 04 & $\Delta 0$ & العبارة & \multirow{2}{*}{ الفراغ } \\
\hline 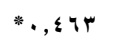 & $*, \leqslant 4$ & $* *, ., \Delta V$ & $*, r \wedge 4$ & $*, r q \varepsilon$ & $* * *^{*}$, IV & معامل الارتباط & \\
\hline
\end{tabular}




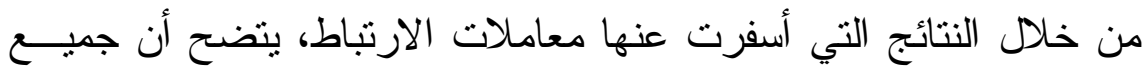

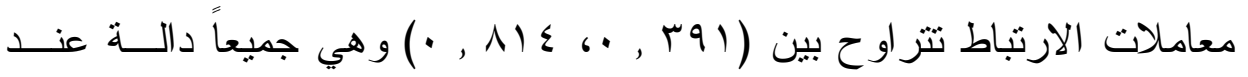

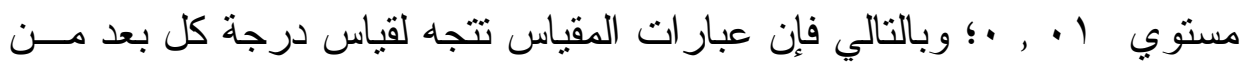

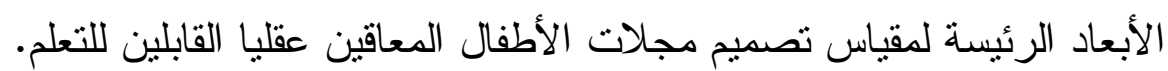
ولتحديد ددي اتساق درجة الأبعاد الرئيسية، و الدرجة الكلية للمقياس، نـــ حساب معاملات الارتباط بين درجة كل بعد رئيسي، و الدرجة الكلية للمقيــاس،

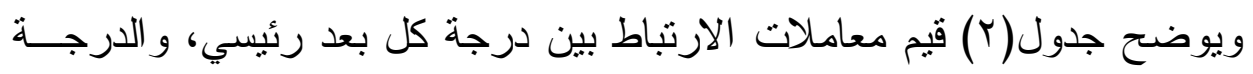

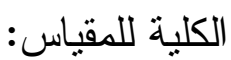

$$
\text { جدول (r) }
$$

معاملات الارتباط بين درجة كل بعد رئيسي مع الارجة الكلية للمقياس

\begin{tabular}{|c|c|c|c|}
\hline مستوي الدالاة & معامل الارتباط مع الدرجة الكلية & أبعاد المقياس & م \\
\hline$\cdot, .0$ & $\because \cdot, \varepsilon \cdot \Gamma$ & 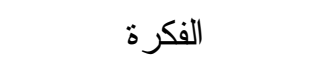 & 1 \\
\hline$\cdot, .0$ & $* \cdot, \varepsilon \mid \varepsilon$ & القطع - مع & r \\
\hline$\cdot, .0$ & $* \cdot, \sum \vee 1$ & الغلاف الخارجي & r \\
\hline$\cdot, \cdot 1$ & $* * *, \sum V \vee$ & بطن الغلاف & $\varepsilon$ \\
\hline$\cdot, .0$ & $* \cdot, \Gamma 9 \wedge$ & صفحة العنوان الداخلي & 。 \\
\hline$\cdot, \cdot 1$ & $* *, 01$. & المتن & 1 \\
\hline$\cdot, \cdot 1$ & $* *, T Y A$ & الرسوم و الصور & $\checkmark$ \\
\hline$\cdot, .0$ & $*, \sum \vee r$ & الألو ان & $\wedge$ \\
\hline$\cdot, .0$ & $*^{*} \cdot, \leq \leqslant 7$ & 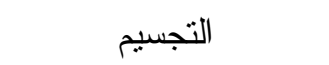 & 9 \\
\hline$\cdot, .0$ & $* \cdot, \varepsilon \Gamma \leq$ & الفراغ & 1. \\
\hline \multicolumn{2}{|c|}{ (***) دال عند ا •,. } & \multicolumn{2}{|c|}{ (*) دال عند ه.,. } \\
\hline
\end{tabular}


من خلال النتائج التي أسفرت عنها معاملات الارتباط، يتضح أنها جميعاً

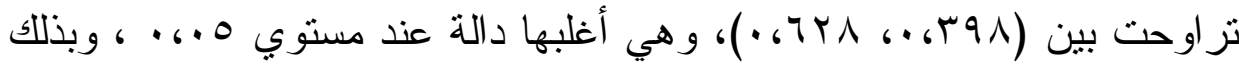
يكون المقياس مُناسباً للتطبيق علي مجموعة البحث الأساسية .

\section{ب - حساب الثبات لمقياس تصميم المجلة:}

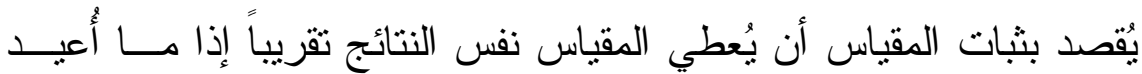

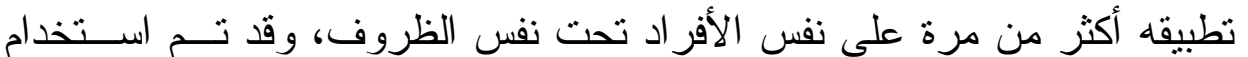

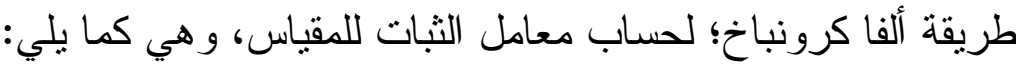

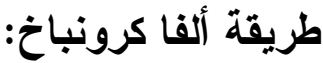

بعد تطبيق المقياس على مجموعة التجربة الاستطلاعية، تم حساب معامل

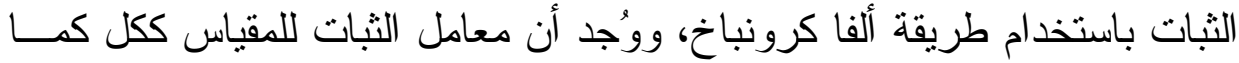
يحددها تطبيق طريقة ألفا كرونباخ على النحو الذي يوضحه جدول (ب): جلول (r) معامل ثبات (ألفا كرونباخ) للمقياس

\begin{tabular}{|c|c|c|c|c|c|c|}
\hline معامل ثبات ألفا & التباين & $\varepsilon$ & b & ن & أبعاد مقياس تصميم & s \\
\hline$\cdot, \mathrm{VT}$. & $1 \leqslant, 07$ & r,A & $r 7,1 V$ & 7 & الفكرة & 1 \\
\hline$\cdot, \vee \circ \wedge$ & $r \cdot, r \cdot$ & $\varepsilon, \leqslant 9$ & $r \leq, \cdot V$ & 7 & القطع & r \\
\hline$\cdot, 107$ & Y), q. & $\varepsilon, \uparrow \wedge$ & $r \leq, \varepsilon$. & 7 & الغلاف الخارجي & $r$ \\
\hline$\cdot, V \leq$. & $1 \varepsilon, \wedge V$ & 「,人т & $r r, O V$ & 7 & بطن الغلاف & $\varepsilon$ \\
\hline$\cdot, \vee \vee V$ & $r \cdot, r_{1}$ & $\varepsilon, 0$. & $r$ r & 7 & صفحة العنوان الاخلي & $\bullet$ \\
\hline$\cdot, \vee \vee 74$ & $1 \wedge, \cdot 1$ & $\varepsilon, r \varepsilon$ & rr,Ar & 7 & المتن & 7 \\
\hline$\cdot, 700$ & $1 \leq, 1 V$ & $r, v \uparrow$ & rT,Tr & 7 & الرسوم و الصور & v \\
\hline$\cdot, V Y T$ & $1 \leq, 11$ & $r, v \uparrow$ & $1 \wedge, 7$ & 7 & الألموان & $\wedge$ \\
\hline$\cdot, 79$. & 17,07 & $r, \wedge r$ & $r \varepsilon, 1 V$ & 7 & التجسيم & 9 \\
\hline$\cdot, V \cdot r$ & $\Lambda \wedge, r$. & $\varepsilon, \varepsilon 9$ & Yo, $\cdot V$ & 7 & الفر اغ & 1. \\
\hline$\cdot, \vee \vee$. & $1 \wedge 0,1 \mu$ & $|r, 7|$ & $1 \wedge \vee, 1$. & 7. & المقياس ككل & \\
\hline
\end{tabular}


يتضح من جدول (r) أن قيمة معامل الثبات للمقياس ككل كما أسفر عنها

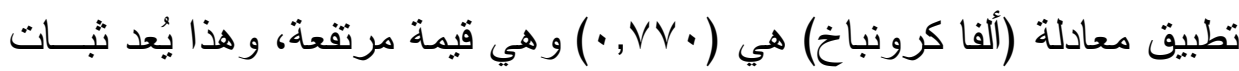
المقياس قيد البحث.

ج- زمن المقياس: تم حساب الزمن المستغرق في الإجابة لكــل طالبــة

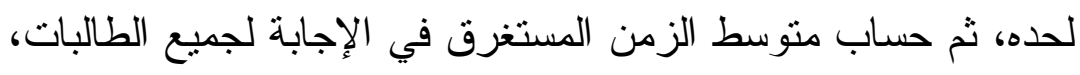

$$
\text { ومن ثم تحدد زمن المقياس في (• ؟) دقيقة. }
$$

•) الصورة النهائية لمقياس تصميم المجلة":

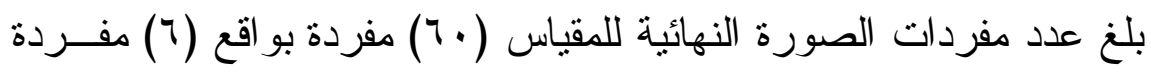

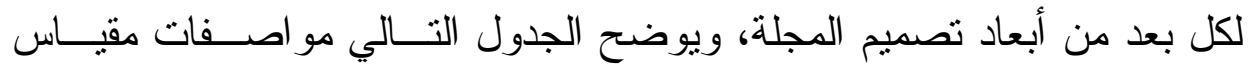
تصميم المجلة.

جدول (؛ ) مو اصفات مقياس تصميم المجلة

\begin{tabular}{|c|c|c|c|c|}
\hline النسبة المئوية للمفردات & أرقام البنود & عدد البنود & بنود المقياس & 5 \\
\hline$\% 1$. & $7: 1$ & 7 & الفكرة & 1 \\
\hline$\% 1$. & Ir:V & 7 & القطع & $r$ \\
\hline$\% 1$. & $11: 14$ & 7 & الغلاف الخارجي & $r$ \\
\hline$\% 1$. & $r \leqslant: 19$ & 1 & بطن الغلاف & $\varepsilon$ \\
\hline$\% 1$. & r.: ro & 7 & صفحة العنوان اللاخلي & 0 \\
\hline$\% 1$. & ו & 7 & المتن & 7 \\
\hline$\% 1$. & $\varepsilon r: r V$ & 7 & الرسوم و الصور & $v$ \\
\hline$\% 1$. & $\leqslant \Lambda: \leqslant \mu$ & 7 & الألوان & $\wedge$ \\
\hline$\% 1$. & $0 \leqslant: \leqslant 9$ & 7 & التجسيم & 9 \\
\hline$\% 1$. & $7 .: 00$ & 7 & الفراغ & 1. \\
\hline$\% 1 \ldots$ & $7 .: 1$ & 7. & المجموع & \\
\hline
\end{tabular}

" ملحق (ץ) مقياس تصميم المجلة. 


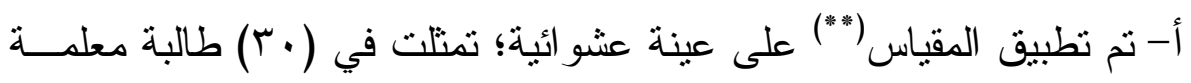

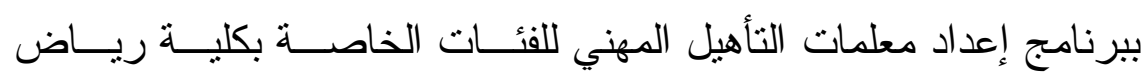
الأطفال. ب-تم تفريغ استجابات الطالبات على المقياس، وتحويلها إلى قيم وزنية يمكن التعامل معها إحصائيا. ج-تم حساب متوسط درجات الطالبات في كل بعد من أبعاد مقياس تــصميم

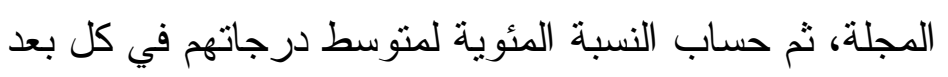

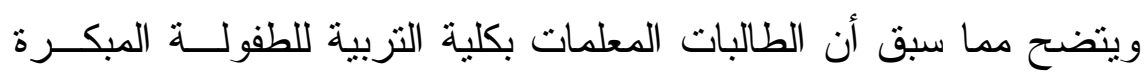

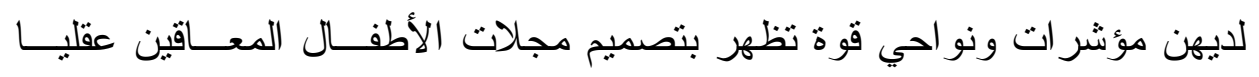
القابلين للتعلم؛ الأمر الذي يثبت فاعلية البرنامج التدريبي للطالبة المعلمة لتصميم المجلة المصورة اللازمة لتقديم مهار ات التعايش للأطفال المعاقين عقليًا (القابلين للتعلم)

وبذلك تكون تمت الإجابة على السؤال الثاني من مشكلة البحث وهو: ما

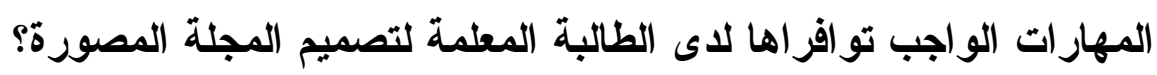
بناء البرنامج التدريبي: للإجابة على السؤال الثالث من أسئلة الاراسة الأي نص على: كيف يمكن بناء برنامج تدريبي للطالبة المعلمة لتصميم المجلة المصورة اللازم لتقديم مهار ات التعايش للأطفال المعاقين عقليًا القابلين للتعلم؟ بلاهي ** ملحق (r) : مقياس تصميم مجلة الأطفال المعاقين عقليا القابلين للتعلم للطالبات معلمات ريــاض الاض الأطفال 


\section{تم إعداد البرنامج التدريبي وفقا للإجر اءات التالية: (1) تعريف البرنامج التدريبي:}

يقصد بالبرنامج التثريبي في هذا البحث مجمو عة من الخبر ات التدريييــة

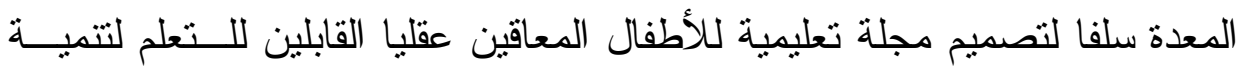

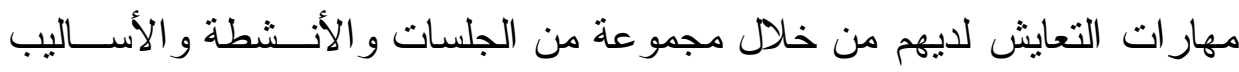

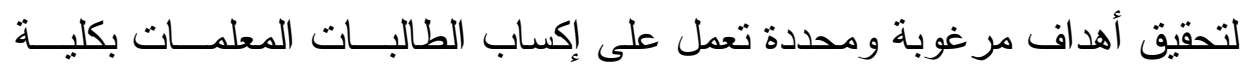
رياض الأطفال مهار ات تصميم مجلات تعليمية للأطفال المعاقين عقليا القـابلين للتعلم.

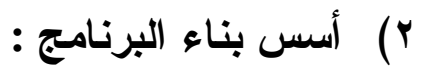

توصلت الباحثة من الدر اسات السابقة و الإطار النظري بوضع أسس بنــاء البرنامج التنريبي للطالبة المعلمة، ومن أهم هذه الأسس ما يلي :

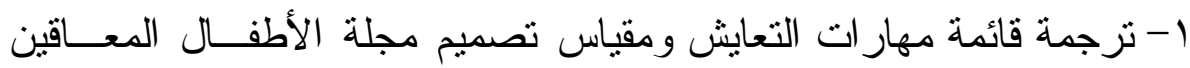

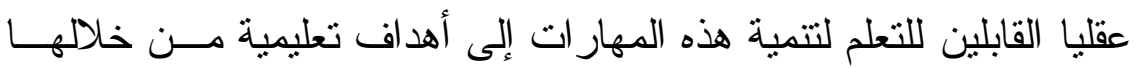

$$
\text { تحدد الأهداف الخاصة بالبرنامج. }
$$

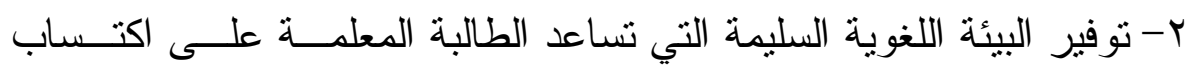
مهار ات تصميم مجلة الطفل اللازمة لتتمية مهار ات التعايش لدى الأطفال المعاقين عقليا القابلين للتعلم. ب- التركيز على مهار ات تصميم مجلات الأطفال لهؤلاء الطالبات المعلمــات و التي تمكنهن من تعليم الاطفال المعاقين عقليا مهار ات التعايش.

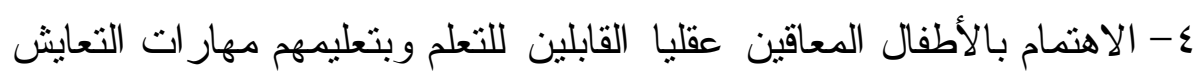

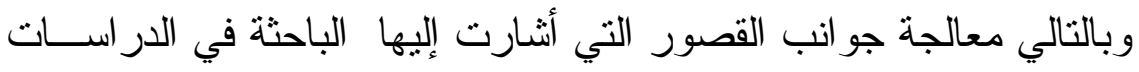
السابقة بعدم الاهتمام بهذه الفئة وخصوصا في تتمية مهار ات التعايش. 
ه- مر اعاة خصائص نمو الأطفال المعاقين عقليا القابلين للـتـعلم فــي بنـــاء

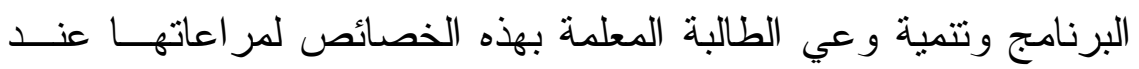
التخطبط و التنفيذ و التقويم لمعايير تصميم المجلة.

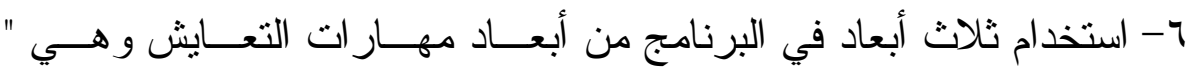

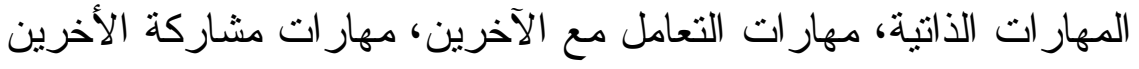

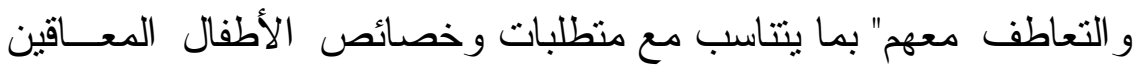
عقليا القابلين للتعلم.

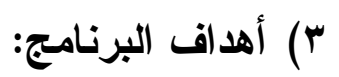
أ- الأهداف العامة للبرنامج:

يهدف البرنامج التدريبي، في الدراسة الحالية إلى تدريب الطالبة المعلدــة

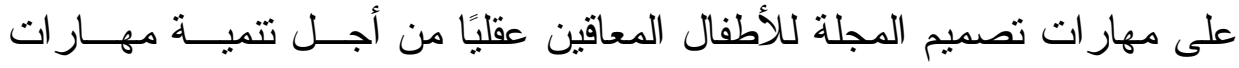

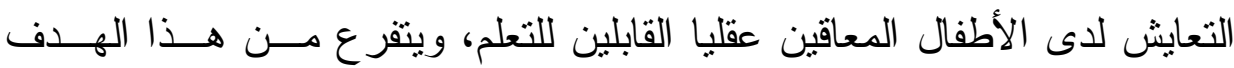

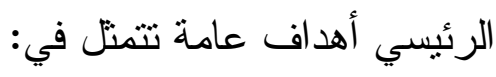
- - إكساب الطالبة المعلمة مجموعة من مهار ات تصمم المجلة و التــي تــم تفرديها في عشرة أبعاد على النحو التالي:

$$
\begin{aligned}
& \text { • م الفكرة. } \\
& \text { • • (القطع. } \\
& \text { • الغلاف الخارجي. } \\
& \text { •بطن الغلاف. } \\
& \text { •صفحة العنوان الداخلي. } \\
& \text { • • • • }
\end{aligned}
$$




$$
\text { • • • • الرسوم و الصور • التجو • }
$$

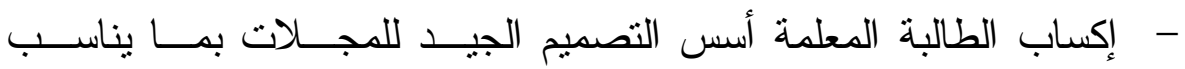
خصائص الطفل المعاق عقليا القابل للتعلم.

- - إكساب الطالبة المعلمة التتفيذ الجيد لمجلات مناسبة للطفل المعاق عقليــا

$$
\text { القابل للتعلم. }
$$

- - إكساب الطالبة المعلمة مهار ات تتمية مهار ات التعــايش لــدى الأطفـــال المعاقين عقليا القابلين للتعلم من خلال المجلات. - تزويد الطالبة المعلمة بالمهار ات اللازمة لاستخدام الوســائل الإعلاميـــة

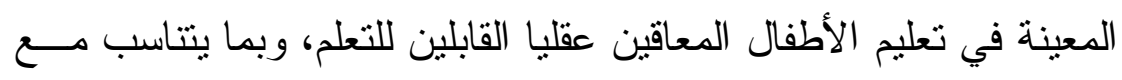

$$
\text { قدر اتهم وخصائصهم. }
$$

ب - الأهداف الخاصة للبرنامج:

يمكن وصف الأهداف الخاصة بأنها محـددة و إجر ائيــة، تـصف الأداء المتوقع من الطالبات المعلمات بعد الانتهاء من تطبيق البرنامج، وتتمنل الأهداف

$$
\text { فيما يلي: }
$$

1- إكساب الطالبة المعلمة مجموعة من مهار ات تصميم مجلات الأطفال المعاقين عقليا القابلين للتعلم؛ ويتوقع بعد دراستها لوحدات البرنامج أن

$$
\text { تكون قادرة على معرفة: }
$$

- الفكرة التي تقوم عليها مجلة وكيفية تقديم مهار ات التعايش من خلالها. - أبعاد المجلة المناسبة للأطفال المعاقين عقليا القابلين للتعلم. 


$$
\begin{aligned}
& \text { - المو اصفات المناسبة للغلاف الخارجي للمجلة. } \\
& \text { - كيفية تصميم بطن غلاف المجلة. } \\
& \text { - الثروط الو اجب تو افرها في صفحة العنوان المدخلي. }
\end{aligned}
$$
- معرفة معايير الرسوم و الصور و الألوان المناسبة للأطفــال المعــاقين عقليا القابلين للتعلم. r- إكساب الطالبة المعلمة مجموعة من مهار ات التعايش الواجب تقديمها

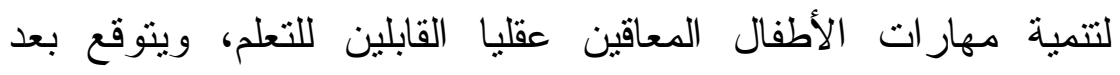
در استها للبرنامج أن تكون قادرة على أن:

- تتعرف على أساليب العناية الثخصية المقدمة للأطفال المعاقين عقليا .

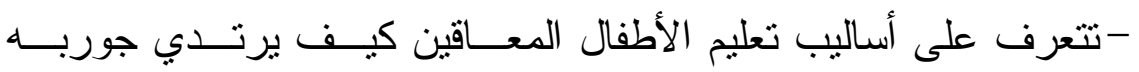
وحذائه.

-تعود الطفل على الاهتمام بنظافته الشخصية.

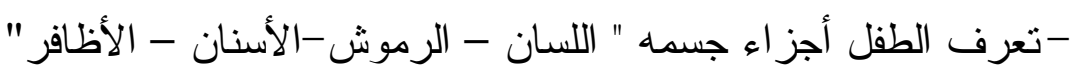
-تعلم الطفل التقرقة بين الملابس الصيفية والثتوية.

$$
\begin{aligned}
& \text {-تعود الطفل على الالتز ام بأدوات الطعام. } \\
& \text {-تدرب الطفل كيف يتعامل مع الأخرين. } \\
& \text { - تهذب سلوكيات الأطفال. } \\
& \text { ؛ ) محتوى البرنامج: }
\end{aligned}
$$

روعي بعض الخصائص عند اختيار المحتوى في الاراسة الحالية ومنها أن:

$$
\text { •يرنبط بأهداف البرنامج التدريبي. }
$$

• يتضمن مهار ات تصميم مجلات الأطفال المعاقين المناسبة اللازمة لتتميــة مهار ات التعايش لدى الأطفال المعاقين عقليا القابلين للتعلم. 
" يكون صادقا بحيث يــضمن معلومــات دقيقـة وخاليــة مسـن الأخطــــاء العلمية.

• بر اعي حاجات الطالبات المعلمات التي يحتجن إليها في أعمالهم، إذ يمكـن الاستفادة منها في المجال العلمي. • بر اعي الفروق الفردية بين الطالبات المعلمات. • يكون مرنا بحيث يمكن التعديل في مضمونه إذا تطلب الأمر . • ير اعي الدقة في الإخر اج و العرض بطريقة شيقة. ولبناء محتوى البرنامج اتبع الباحثة الخطوات الأتية: - الاستفادة من الإطار النظري و الدر اسات السابقة. - الاطلاع على محتوى البر امج المقدمة للمعلمين. - الاطلاع على بعض المر اجع التي اهتمت بتصميم بر امج تدريبية. - بناء اللقاءات من الموضو عات و المو اقف التربوية و التطبيقات. •) طرق وأسـاليب التقويم:

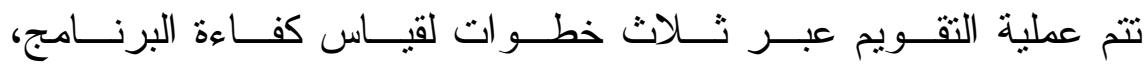
ومدى تلبيته للاحتياجات التدريبية التي صمدت من أجله، وتتمنتل هذه الخطــــات

بعد تصميم البرنامج التذريبي، تم عرضه على مجموعة متخصصة مسن

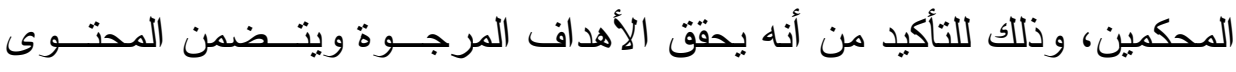
المناسب من حيث الاختيار و التنظيم، وتم إجر اء هذا التقويم قبل تطبيق البرنامج 
وذللك بهدف بيان مدى فعالية البرنامج لتصميم المجلة المصورة اللازمة لتقـديم مهار ات التعايش للأطفال المعاقين عقليًا (القابلين للتعلم). • متابعة البرنامج في أثناء التنفيذ: تعد من المهام الرئيسية للطالبات المعلمات، ونم متابعة البرنامج التــريبي

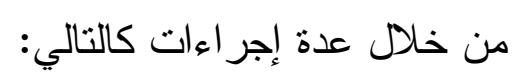
- تقويم الطالبات المعلمات في نهاية كل جلسة.

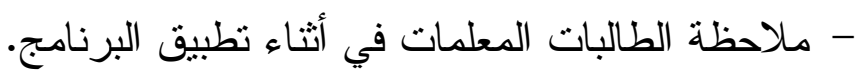
• تقويم البرنامج بعد التنفيذ:

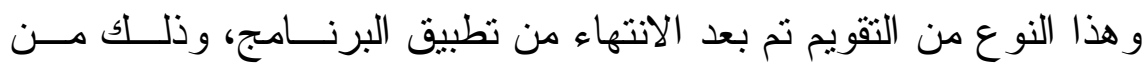

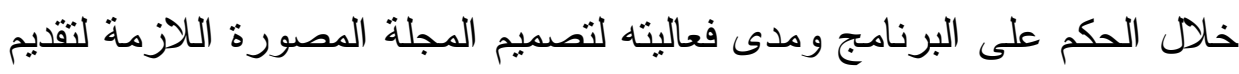

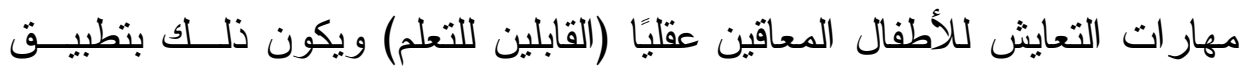
بطاقة الملاحظة ومقياس مهار ات تصميم المجلة المصورة تطبيقا بعديا. 4) ضبط البرنامج التّريبي:

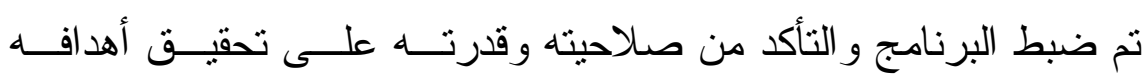

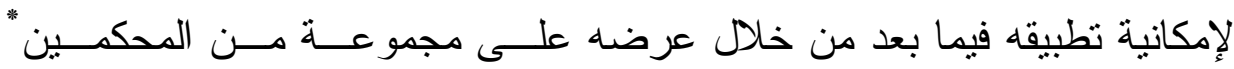

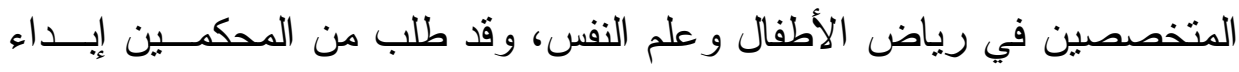

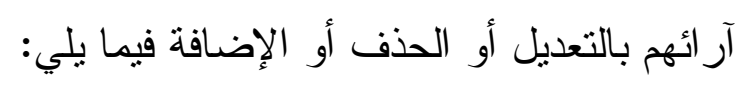

1- مدى مناسبة معايير تصميم المجلة المصورة لمهار ات التعايش. r- مدى مناسبة أنثطة مهارات التعايش للأطفال المعاقين عقليا القابلين للتعلم. • ملدق ( () : قائمة بأسماء السادة المحكمين على أدو ات البحث 
وقد رأى المحكمين صـلاحية البرنامج لتحقةــق أهدافـــهـ المرجـــوة منـــه،

لتصميم المجلة المصورة اللازمة لتقديم مهار ات التعايش للأطفال المعاقين عقليًا

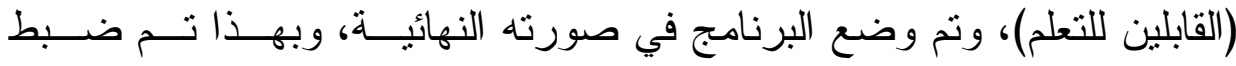
البرنامج و التأكد من صلاحيته للتطبيق. (") V ) تطبيق البرنامج التدريبي: -

تم تطبيق البرنامج التدريبي على عينة الدراسة التي طبــق عليهـــا قبليــاــا

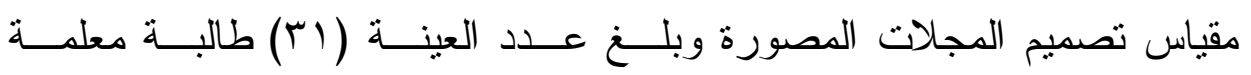
(المجمو عة التجرييية). • ت تنفيذ البرنامج:

تم في هذه المرحلة التطبيق الفعلي للبرنامج، حيث التفاعل بــين الباحثــة و الطالبات المعلمات حول موضوع البرنامج التدريبي، فقد حرصت الباحثة على تقديم الجانبين النظري و العملي بطريقة متكاملة، بحيث يتضمن كل جلسة عرضا

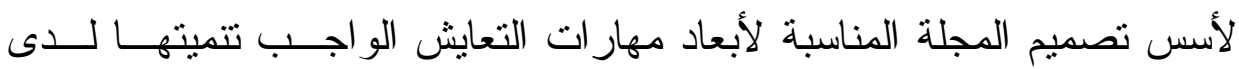
الأطفال المعاقين عقليا القابلين للتعلم.

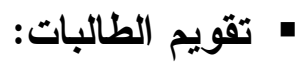

تم تقويم الطالبات المعلمــات قبليــا، لتعـرف مـــدى تــو افر مهـــار ات تصميم المجلات المصورة لتنمية مهار ات التعـايش لـدى الأطفــال المعــاقين

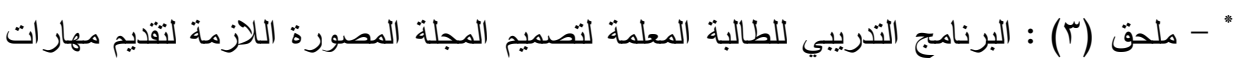

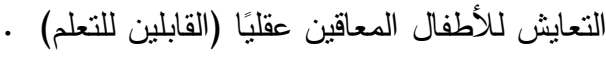


عقليا القابلين للتعلم من خلال بطاقة الملاحظـــة ومقيــاس تــصميم المجــلات

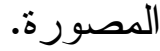

وبعد الانتهاء من تطبيق البرنامج تم التعرف على مدى فعاليته في تدريب الطالبات المعلمات لتصميم المجلة المصورة اللازمة لتقديم مهــار ات التعـايش للأطفال المعاقين عقليًا (القابلين للتعلم)، وذلك من خلال التطبيق البعدي لكل من بطاقة الماحظة ومقياس تصميم المجلات المصورة للأطفــال المعــاقين عقليــا القابلين للتعلم، ومعالجة النتائج إحصائيا. إعداد بطاقة ملاحظة أدائ الطالبات المعلمات: للإجابة على السؤال الرابع من أسئلة البحث الأي نص على:

ما فعالية البرنـامج التدريبي لتدريب الطالبة المعلمــة لتــصميم المجلـة المصورة اللازم لتقديم مهارات التعايش للأطفال المعاقين قابلين التعلم؟ تم إعداد بطاقة ملاحظة الأداء التصميمي و التدريسي للطالبات المعلمــات لأنها تعد من أهم الأدوات في عملية تقويم أداء الطالبات المعلمات، فالماحظــــة تقيد في معرفة سلوك المعلم التعليمي التعلمي داخل غرفة الصف الدر اسي ومــن

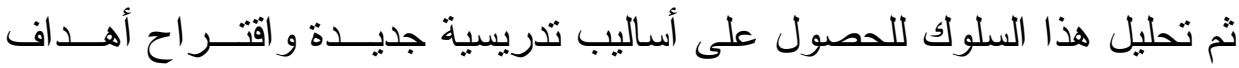
تعليميه تعالج نقاط الضعف وتعزز من نقاط القوة، وتستخدم هـــهـ الأداء عنــدما يشعر الباحثة بأن الأدوات الأخرى غير كافية للحصول على مــا يريـــده مــن معلومات أو بيانات لبحثة.

ولما كان البحث الحالي يستهدف بناء برنامج تــدريبي للطالبــة المعلمـــة لتصميم المجلة المصورة اللازمة لتقديم مهار ات التعايش للأطفال المعاقين عقليًا 
(القابلين للتعلم)، فقد قامت الباحثة بإعداد بطاقة ملاحظة لملاحظة أداء الطالبات

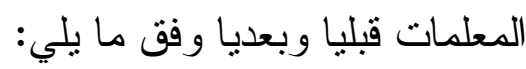
أ- الهُف من بطاقة الملاحظة:

لما كان من أهداف إكساب الطالبة المعلمــة مهــار ات تــصميم المجلـــة

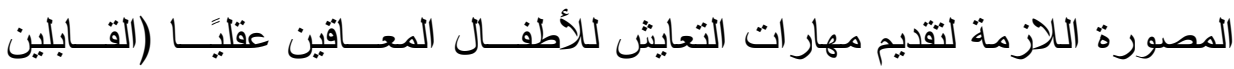

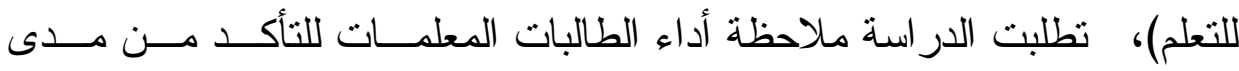

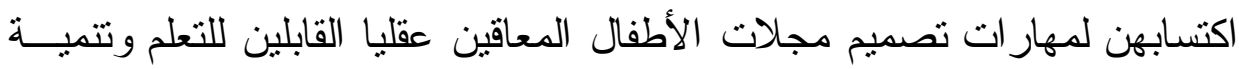
مهار ات التعايش لديهن من خلال هذه المجلات؛ حتى يتسنى للباحثة للحكم على الـى

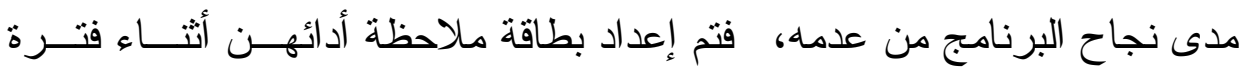

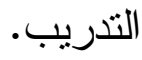

ومن ثم تهدف بطاقة الملاحظة في الدر اسة الحالية إلى تعرف مدى تو افر

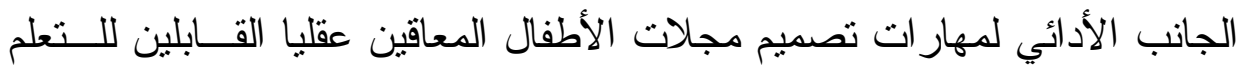

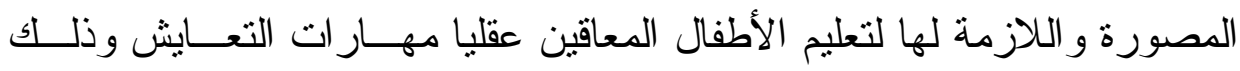

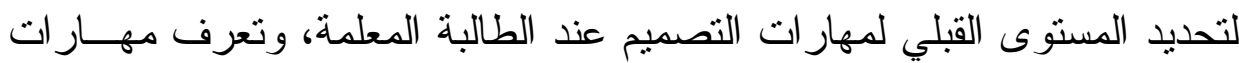

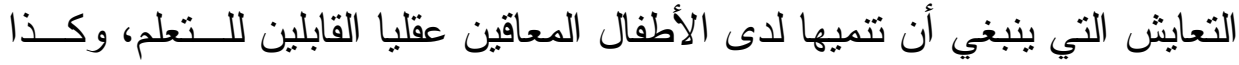
لتحديد المستوى البعدي لها عقب تطبيق البرنامج. ب- صياغة بنود بطاقة الملاحظة: تم تقسيم مهار ات التعايش المستخدمة في الدراســـة الحاليـــة (المهــار ات

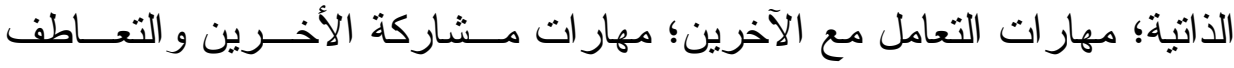

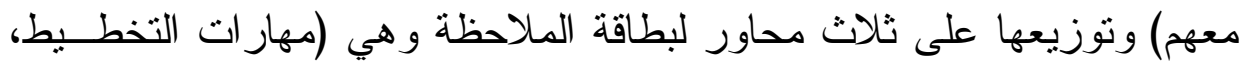


ومهار ات التنفيذ، ومهار ات التقويم)، وقد بلغ عدد بنود بطاقـــة الملاحظــــة (ع 7) بندا، وقد نم مر اعاة ما يلي في صباغة هذه البنود. - - ألا يحتمل البند أو العبارة أكثر من معنى واحد.

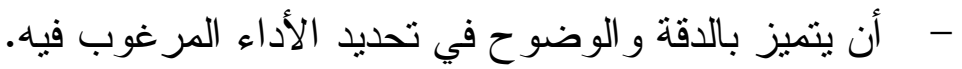
- - - أن يصف مكون و احد من السلوك. بالك. - - - - - أن يرنبط بأهداف البرنامج. - - أن يرتبط بالدحور التابع له في بطاقة الملاحظة. • - التقدير الكمي لأداء الطالبة المعلمة:

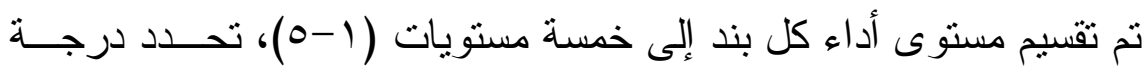

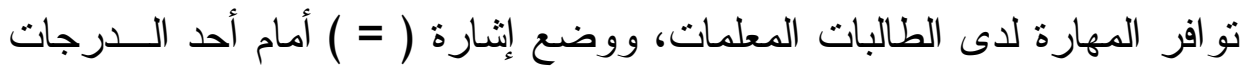
كما يلي : مان

$$
\begin{aligned}
& \text { مستوى | = ضعيفة جدا. } \\
& \text { مستوى r = ضعيفة. } \\
& \text { مسنوى r = متوسط. } \\
& \text { مستوى ع = قوية. } \\
& \text { مستوى } 0 \text { = قوية جدا. }
\end{aligned}
$$

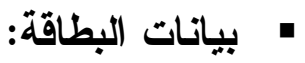

حددت الباحثة بطاقة ملاحظة لكل طالبة معلمة، وقد اثتنملت على:

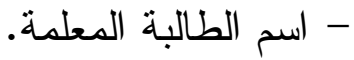

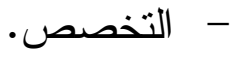
- استـم جلسة دهار ات التعايش. 


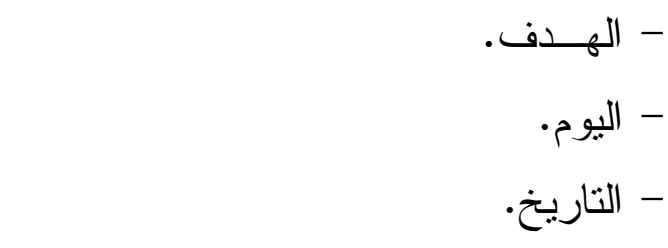

ج- التجريب الاستطلاعي لبطاقة الملاحظة:

قامت الباحثة بتطبيق البطاقة على مجموعة استطلاعية (غيـر مجموعــة

البحث الأساسية) مكونة من (·r) طالبة معلمة من طالبات كلية رياض الأطفال بيرنامج إعداد معلمات التأهيل المهني للأطفــال ذوي الاحتياجــات الخاصـــة / جامعة المنصورة وذللك بهدف: ( ) (1) (1) حساب صدق البطاقة. r) حساب ثبات البطاقة. r) حساب ثبات الملاحظة الموضو عية (عملية الملاحظة). ع) حساب زمن الماحظة. وفيما يلي تقصيل ذلك: ( ) حساب الصدق للبطاقة "صدق الاتساق الداخلي" " التجانس الداخلي": تم حساب الصدق للبطاقة، بحساب معامل الارتباط بين درجات كل مهارة فرعية لبطاقة الملاحظة مع الدرجة الكلية لكل مهارة رئيسة؛ وذلك كما يوضحه جدول (0): 


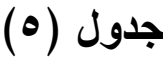

معاملات الارتباط بين درجة كل مهارة فرعية من مهارات البطاقة مع الارجة الكلية لكل مهارة رئيسة

\begin{tabular}{|c|c|c|c|c|c|c|}
\hline 7 & 0 & $\varepsilon$ & $r$ & $r$ & 1 & \multirow{6}{*}{ المجلة المصورة تخطيط } \\
\hline$* *,, \vee \wedge \varepsilon$ & $* *, \wedge Y$ & צ * * * & $* *, \neg \wedge \wedge$ & $* *,,\rceil \vee \wedge$ & $*, \leqslant \Gamma q$ & \\
\hline Ir & 11 & 1. & 9 & $\wedge$ & v & \\
\hline$*, \Sigma Y V$ & $* *,, V T V$ & $*,, \varepsilon \varepsilon$. & $* *,, 0 \wedge \wedge$ & $* *, 09 r$ & **, & \\
\hline 11 & iv & 17 & 10 & $1 \varepsilon$ & Ir & \\
\hline ד ד & **, ז & $* *, \neg \wedge 0$ & *., & $* *,, \vee \wedge \wedge$ & $* *, V \cdot V$ & \\
\hline$r \leq$ & $r r$ & rr & Y & $r$. & 19 & \multirow{10}{*}{ المجلة المصورة تنفيذ } \\
\hline$*,, \leq 00$ & **, orv & $*, \varepsilon r q$ & $* *, 01 \mathrm{~V}$ & $* *, 0$. 9 & *., & \\
\hline r. & rq & $r \wedge$ & $r V$ & Y q & ro & \\
\hline$*, \varepsilon Y Y$ & ***, , Tr & $* *, V Y T$ & $* *, 0 \leq \leqslant$ & * •, $\Sigma$ r & $* *, 0$ or $q$ & \\
\hline צמ & ro & T & سץ & Tr & ו & \\
\hline$*$, * $\varepsilon \leqslant$. & $* *, 00 \mathrm{~V}$ & $*,, \leq \leqslant 9$ & $* *$, or V & $* *$, orr & $*, \leq 10$ & \\
\hline$\varepsilon r$ & $\varepsilon 1$ & $\varepsilon$. & rq & rᄉ & rV & \\
\hline \multirow[t]{3}{*}{$* *,>10$} & $* *, 7,1$ & $* *, 7 \cdot V$ & $* *, 0 \wedge r$ & $* *,, \vee \Gamma \wedge$ & $* *, 701$ & \\
\hline & & & & $\varepsilon \varepsilon$ & $\varepsilon r$ & \\
\hline & & & & $* *, T r T$ & *., $\_r r$ & \\
\hline 0 . & $\leq 9$ & $\varepsilon \Lambda$ & $\varepsilon V$ & $\varepsilon 7$ & $\leqslant 0$ & \multirow{8}{*}{ المجلة المصورة تقويم } \\
\hline$* *, 71$. & $* *, T r Y$ & $* *, \vee \backslash \wedge$ & $* *, 0$ \% $q$ & ***, • ד ד & $* *, 7,7$ & \\
\hline 07 & 00 & $0 \leqslant$ & $\Delta r$ & $\Delta r$ & 01 & \\
\hline$* *, 09 \pi$ & $* *, V T \leq$ & $* *,, 7 \leq \varepsilon$ & $* *, 091$ & $* *, \wedge r r$ & $* *, \wedge I V$ & \\
\hline $7 r$ & 71 & 7. & 09 & 01 & ov & \\
\hline \multirow[t]{3}{*}{$* *,, 770$} & $* *, T V Y$ & $* *, \vee \backslash 1$ & $* * .09$. & $* *, \vee \backslash \leq$ & $* *, 7 r q$ & \\
\hline & & & & $7 \varepsilon$ & שו & \\
\hline & & & & $* *, Y Y{ }^{\prime}$ & $* *, 70 \mathrm{~V}$ & \\
\hline
\end{tabular}

•, • ("***)

(") 
من خلال النتائج التي أسفرت عنها معاملات الارنباط، يتضح أن جميـع

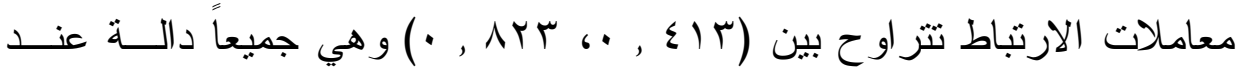
مستوي 0 •، • ؛ وبالتالي فإن المهار ات الفرعية لبطاقة الملاحظة تتجـــه لقيــاس درجة كل مهارة رئيسة من المهار ات الرئيسة لبطاقة الملاحظة.

ولتحديد مدي اتساق المهار ات الرئيسة، والدرجة الكلية لبطاقة الملاحظة، تم حساب معاملات الارتباط بين درجة كل مهارة رئيسة، و الدرجة الكلية لبطاقة الماحظة، ويوضـح جدول(T) قيم معاملات الارنباط بين درجـــة كــل مهـــارة رئيسة، و الدرجة الكلية لبطاقة الملاحظة:

جدول (7)

معاملات الارتباط بين درجة كل مهارة رئيسة مع الارجة الكلية لبطاقة الملاحظة

\begin{tabular}{|c|c|c|}
\hline مستوي الالالة & معامل الارتباط مع الارجة الكلية & مهار ات بطاقة الملاحظة \\
\hline$\cdot, \cdot 1$ & $* *, 779$ & تخطيط المجلة المصورة \\
\hline$\cdot, \cdot 1$ & $* *, 7,1$ & تنفيذ المجلة المصورة \\
\hline$\cdot, .0$ & $*, \varepsilon \vee$. & تقويم المجلة المصورة \\
\hline
\end{tabular}
(**) (*)

من خلال النتائج التي أسفرت عنها معاملات الارتباط، يتضح أنها جميعـاً

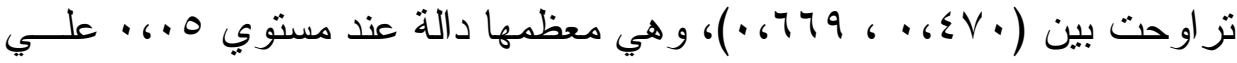
الأقل، وبذلك تكون بطاقة الملاحظة مُناسبة للتطبيق علـي مجموعـــة البحـــث الأساسية . 
r

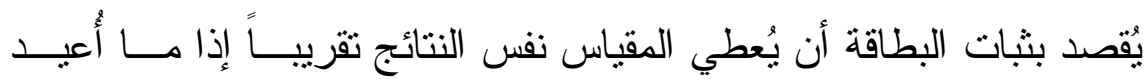

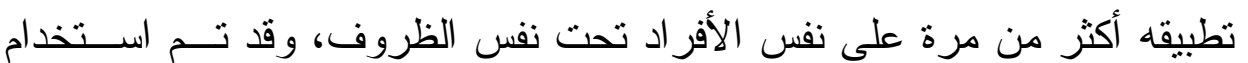
طريقة ألفا كرونباخ؛ لحساب معامل الثبات لبطاقة الملاحظة، وهي كما يلي:

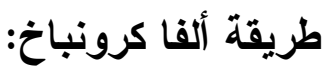
بعد تطبيق بطاقة الملاحظة على مجموعة التجربـــة الاســتطلاعية، تـم

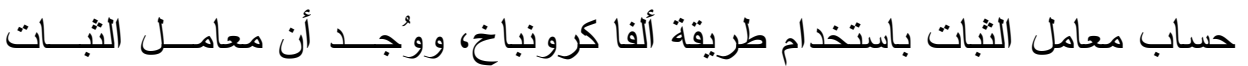
لبطاقة الملاحظة ككل كما يحددها تطبيق الطريقة على النحــو الــذي يوضــــه

\section{جدول (v)}

معامل ثبات (ألفا كرونباخ) لبطاقة الملاحظة

\begin{tabular}{|c|c|c|c|c|c|}
\hline معامل ثبات ألفا كرونباخ & تباين & $\varepsilon$ & م & ن & مهارات بطاقة الملاحظة \\
\hline$\cdot, \wedge \ldots$ & Or,. T & $\vee, \wedge \wedge$ & $r q, \wedge$. & 11 & تخطيط المجلة المصورة \\
\hline$\cdot, \times 17$ & Tr, & $\wedge, 9 \leq$ & $r r, \wedge$. & Y & تتفيذ المجلة المصورة \\
\hline$\cdot, \wedge Y \leq$ & $V Y, \cdot 9$ & $9, \leqslant 9$ & $r \leqslant, r_{0}$ & $r$. & تقويم المجلة المصورة \\
\hline •, & $1 \wedge V, 17$ & (Y,T) & $\wedge \uparrow, \wedge \circ$ & Tד & البطاقة ككل \\
\hline
\end{tabular}

يتضح من جدول (V) أن قيمة معامل الثبات لبطاقة الملاحظة ككـلـ كمـــا

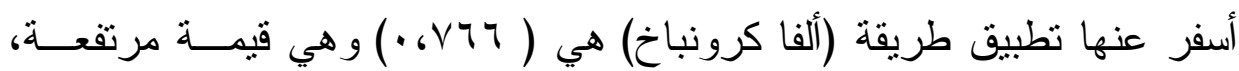
و هذا بُعد ثبات بطاقة الملاحظة قيد البحث. 
r) حساب ثبات الملاحظة "الموضوعية " (عملية الملاحظة):

يُقصد بثبات عملية الملاحظة أن تُعطي نفس النتائج تقريباً إذا مـــا أَعيـد

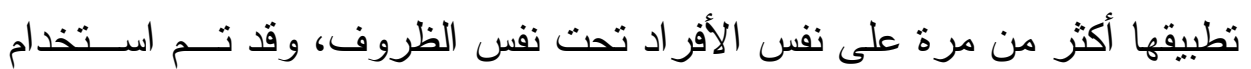
أسلوب معامل الاتفاق بين ملاحظين مستقلين لحساب ثبات عمليـــة الملاحظــــة،

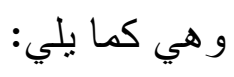

أسلوب معامل الاتفاق بين ملاحظين مستقلين (الباحثة، وملاحظ آخر):

حيث تمّ الاستعانة بأحد المدرسين" بكلية النزبية للطفولة المبكرة/ جامعــة

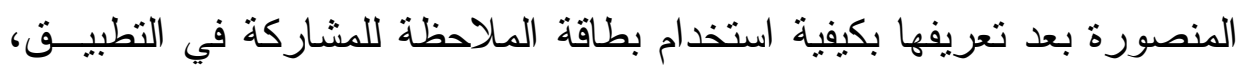

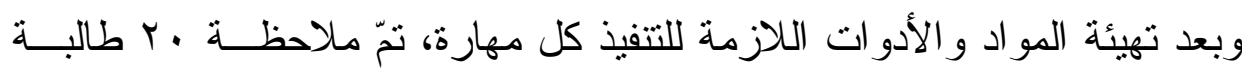

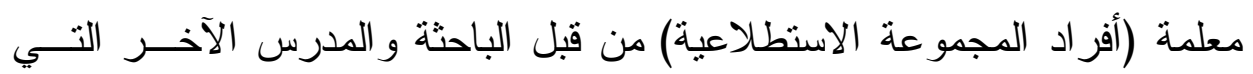

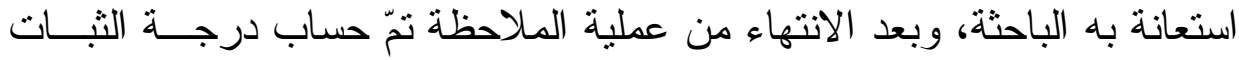
لكل مهارة من المهار ات الرئيسة المكوّنة لبطاقة الملاحظة، وكذلك حساب ثنات البطاقة ككل بتطبيق معادلة كوبر "Cooper" (Cooper, 1974, 39) لحساب نسبة الاتفاق بين ملاحِّين مستقلين، و المتمثلة في المعادلة التالية:

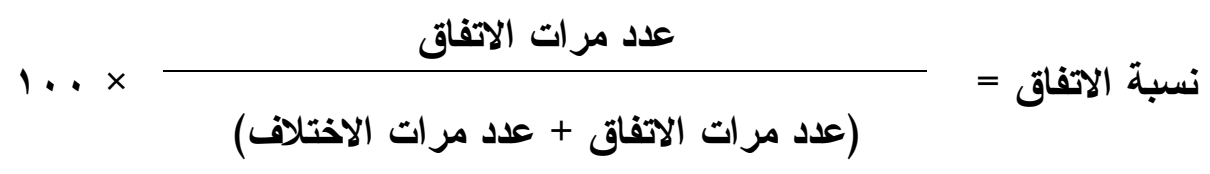

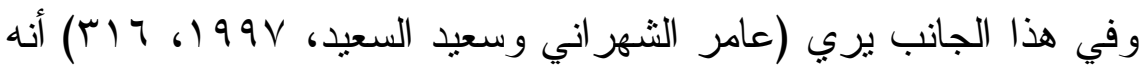

إذا زادت نسبة الاتفاق بين الملاحظين عن (•v\%) في كل مهارة من المهار ات

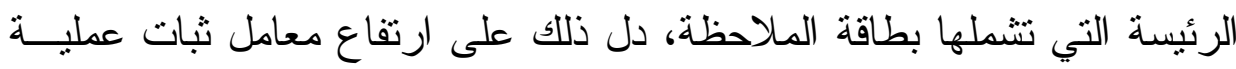
• د. فايزة أحمد عبد الر ازق - مدرس بكلية التربية للطفولة المبكرة / جامعة المنصورة . 


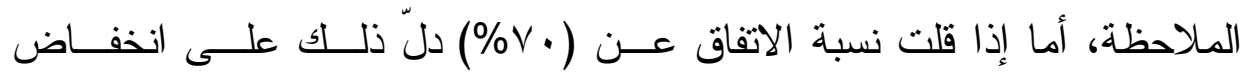

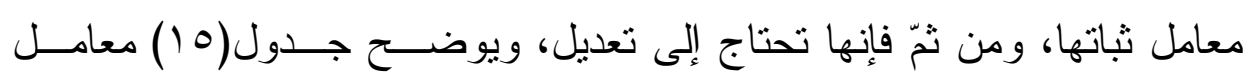

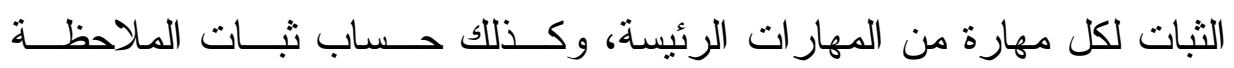

$$
\text { للمهار ات ككل: - n }
$$

\section{جدول (^)}

نسبة الاتفاق بين الملاحظين (ثبات عملية الملاحظة)

\begin{tabular}{|c|c|c|c|c|}
\hline نسبة الاتفاق & عدد مرات الاختلاف & عدد مرات الآفاق & المهــــــــــارة & م \\
\hline$\% \wedge \vee, \bullet$. & $r$. & $1 \leqslant$. & تخطيط المجلة المصورة & 1 \\
\hline$\% a$. & r. & 11. & تنفيذ المجلة المصورة & r \\
\hline$\% q r, v o$ & 1. & 10. & تقويم المجلة المصورة & $r$ \\
\hline$\% q \cdot, r \wedge$ & o. & $\leq v$. & سالى (ثبات البطاقة ككل) & \\
\hline
\end{tabular}

يتضح من جدول (^) أنّ نسبة الاتفاق (ثبات عملية الملاحظـــة) بلغــــ

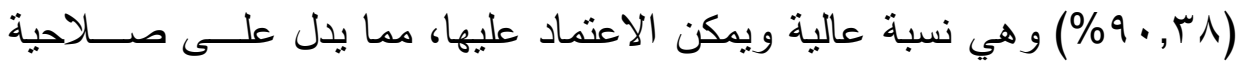

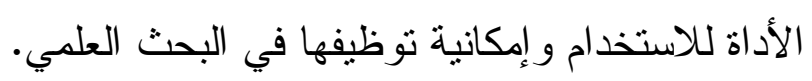

ع) حساب زمن الملاحظة: تم حساب الزمن المستغرق في ملاحظة كـلـ طالبــة على حدة من حيث أطول و أقصر وقت مستغرق، ثم حساب متوسط الــزمن المستغرق في ملاحظة جميع الطالبات، ومن ثم تحدد زمن الملاحظـــة فــي (00) (00) دقيقة. 
د- الصورة النهائية لبطاقة الملاحظة|")

تكونت بطاقة الملاحظة في صورتها النهائية من (ع 7) مفردة، تقيس أداء

الطالبات المعلمات بكلية التربية للطفولة المبكـرة لتـصميم المجلــة المــصورة اللازمة لتقديم مهار ات التعايش للأطفال المعاقين عقليًا (القابلين للتعلم)، ومن ثـــ أصبحت بطاقة الملاحظة صالحة للاستخدام ويمكن الوثوق فــي النتــائج التــي نحصل عليها من خلال تطبيقها على عينة البحث، و الجــدول التــالي يلخــص مو اصفات بطاقة ملاحظة أداء الطالبات المعلمات بكلية ريــاض الأطفــال فــي مهار ات تصميم المجلة المصورة لمهار ات التعايش لدى الأطفال المعاقين عقليــا القابلين للتعلم.

\section{(9) (9) (9)}

مواصفات بطاقة ملاحظة أداء الطالبات المعلمات

\begin{tabular}{|c|c|c|c|}
\hline النسبة المئوية للمفردات & أرقام البنود & عدد البنود & بنود التقييم لبطاقة الملاحظة \\
\hline$\%$ \%, $1 r$ & $1 \wedge-1$ & 11 & تخطيط المجلة المصورة \\
\hline$\% \varepsilon \cdot, 7 r$ & $\varepsilon \varepsilon-19$ & r & تنفيذ المجلة المصورة \\
\hline \% r, ro & $7 \varepsilon-\leqslant 0$ & r. & تقويم المجلة المصورة \\
\hline$\%, \ldots$ & من ا إلى ع & $7 \leq$ & المجموع \\
\hline
\end{tabular}

وبذلك تكون تمت الإجابة على السؤال الرابع من مشكلة البحث وهو: ما فعالية البرنامج التدريبي لتدريب الطالبة المعلمة لتصميم المجلــة المــصورة اللازم لتقديم مهارات التعايش للأطفال المعاقين القابلين للتعلم؟

" - ملحق (V) بطاقة ملاحظة أداء الطالبات المعلمات 


\section{ثانيا: تجربة البحث:

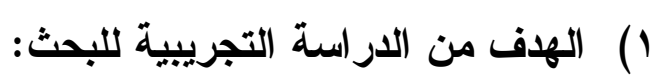

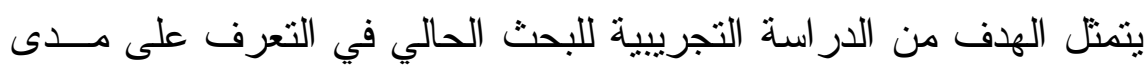

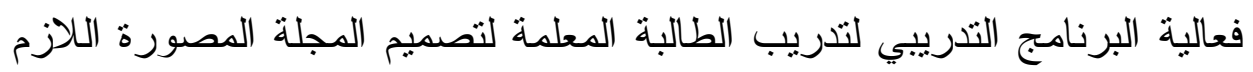

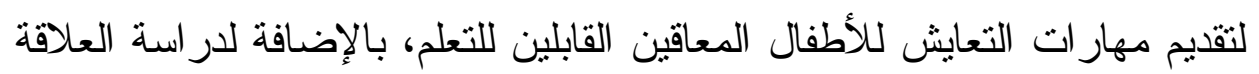

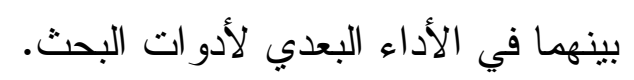

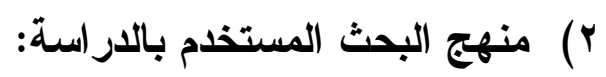

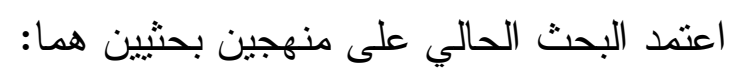

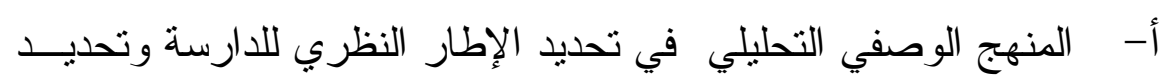

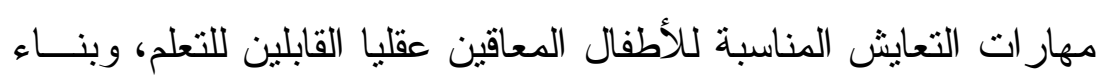

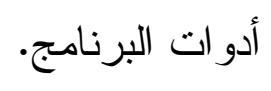

ب- المنهج التجريبي، وذللك للتعرف على فعالية البرنامج التدريبي لتـدريب

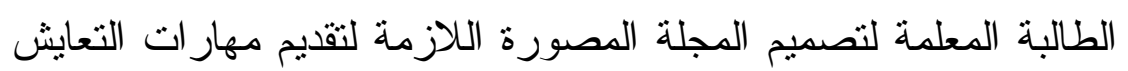
للأطفال المعاقين القابلين للتعلم.

r) متغيرات تجربة البحث: وتتحدد في المتغيرات التالية:

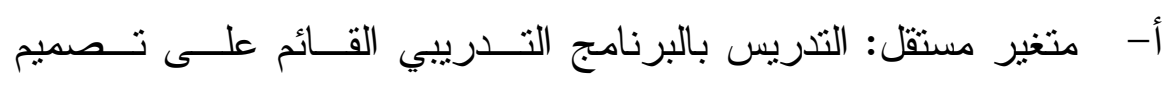

$$
\text { المجلات المصورة. }
$$

ب- متغير تابع: مهار ات التعايش للأطفال المعاقين عقليا القابلين للتعلم. 


$$
\text { ؛ ) التصميم التجريبي للبحث: }
$$

اعتمدت الدر اسة الحالية على تصميم المعالجات التجريبية القبلية و البعدية، وذللك من خلال مجمو عتين: مجمو عة تجريبية و الأخــرى ضـــابطة، ويوضـــح

$$
\text { الثكل التالي التصميم التجريبي للبحث: }
$$

\section{شكل (1)}

التصميم التجريبي للبحث وفق متغير اته

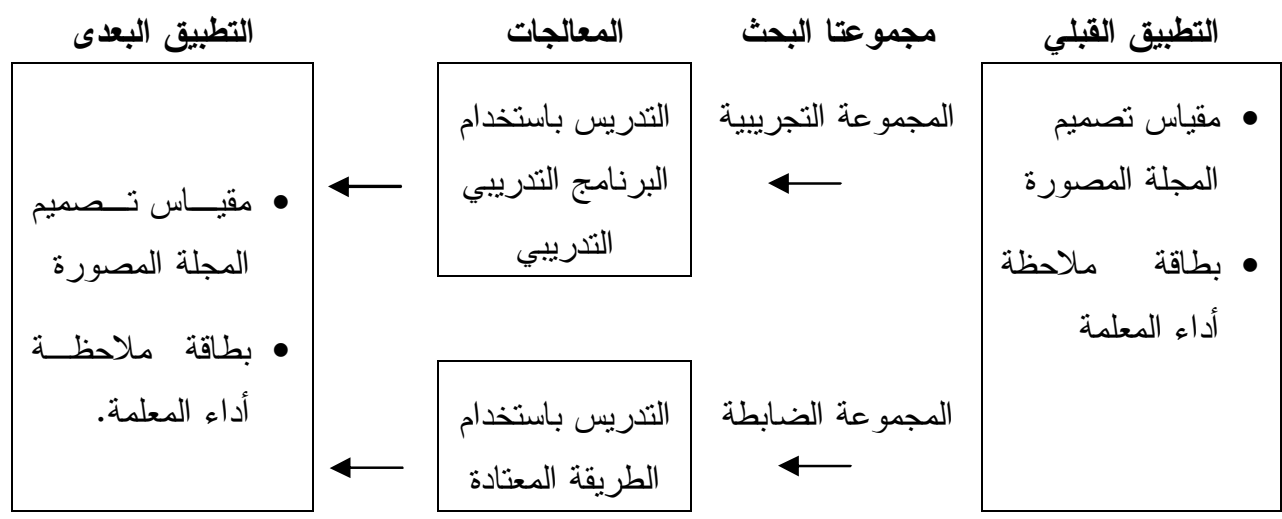

•) اختيار عينة البحث التجريبية:

تم اختيار العينة من طالبات برنامج إعداد معلمات التأهيل المهني للفئات

$$
\text { الخاصة بناء على ما يلي: }
$$

• تم اختيار عينة تمنلت في (Tr) طالبة من طالبات برنامج إعداد معلمــات

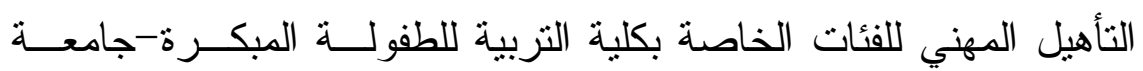

$$
\text { المنصورة. }
$$

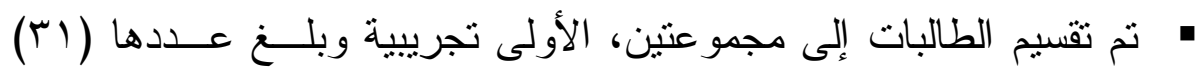

$$
\text { طالبة، و الأخرى ضابطة (ابץ) طالبة. }
$$


• تم إجر اء مقياس تصميم المجلة المصورة لمعرفة مدى قــدرة الطالبــات المعلمات على تصميم المجلات المصورة المناســبة للأطفــال المعـاقين

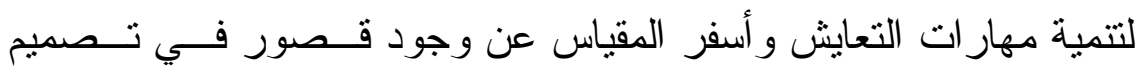

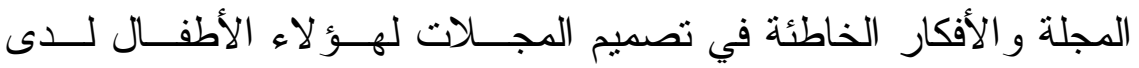

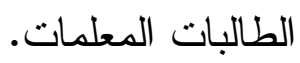

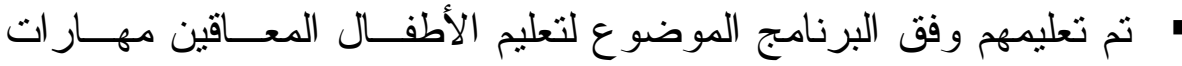

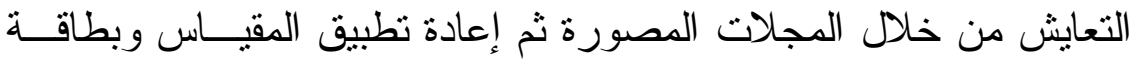

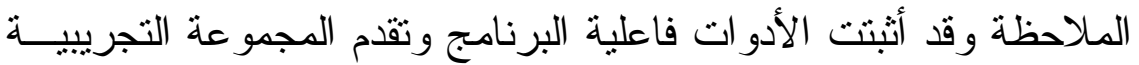

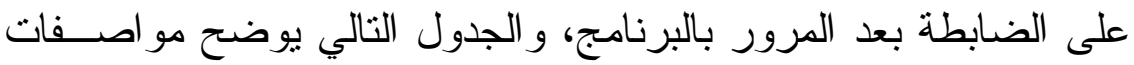

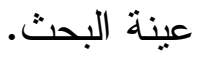
جدول (• (1) توزيع الطالبات عينة البحث

\begin{tabular}{|c|c|c|}
\hline العدد & المعالجة التجريبية & المجموعة \\
\hline ri & 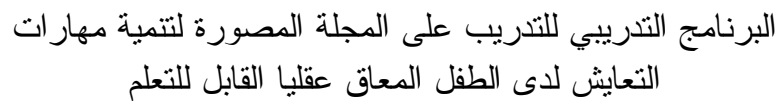 & النجريبية \\
\hline ri & الطريقة الدنبعة في النتريس & الضابطة - مابة \\
\hline r r طالبة & مجمو عتان ومعالجتان & الإجمالى - ل الم \\
\hline
\end{tabular}

• إحصاء قبلي مقياس تصميم المجلة المصورة: التأكد من تكافؤ المجموعتين في المقياس:

استخذمت الباحثة اختبار "ت" لمجموعتنين غير مرتبطنتي؛ لبحــث دلالـــة الفرق بين متوسطي درجات كل من المجموعة التجريبية و الضابطة في مقيــاس

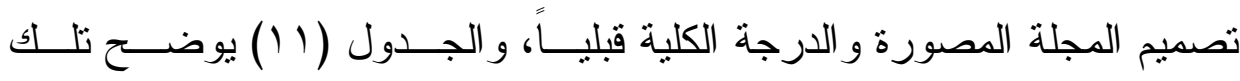

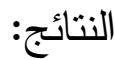




\section{جدول (11)}

قيمة "ت" ودلالتها الإحصائية للفروق بين متوسطي درجات كل من المجموعة

التجريبية والمجموعة الضابطة في مقياس تصميم المجلة المصورة لمهارات التعايش و الارجة الكلية قبلياً

\begin{tabular}{|c|c|c|c|c|c|c|c|c|}
\hline مستوي & الالالة & ت & د. د. & $\varepsilon$ & p & ن & مجموعتا & مهار ات تصميم المصورة \\
\hline غير دالة & •, T०Y & $\cdot, \leqslant \Delta r$ & $\Delta \wedge$ & $1, V_{1}$ & $0,9 \vee$ & ו & ت & \multirow{2}{*}{ الفكرة } \\
\hline & & & & $1, \cdot 7$ & $\bullet, \Lambda$. & M & ض & \\
\hline \multirow[t]{2}{*}{ غير دالة } & $\cdot, V \leq r$ & •, r & $0 \wedge$ & $1,0 r$ & $\bullet, \varepsilon$. & M & ت & \multirow{2}{*}{ القطع } \\
\hline & & & & $1,7 r$ & $0, Y V$ & M & ض & \\
\hline \multirow[t]{16}{*}{ غير دالة } & 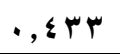 & $\cdot, \vee \vee q$. & $0 \wedge$ & $r, 1$. & $0,0 Y$ & r & ت & \multirow{2}{*}{ الغلاف الخارجي } \\
\hline & & & & $1, \wedge 1$ & 0,11 & M & ض & \\
\hline & $\cdot, \vee \vee ०$. & • מ & $\bullet \wedge$ & 1,71 & $\bullet, V V$ & M & ت & \multirow{2}{*}{ بطن الغلاف } \\
\hline & & & & $1, \cdot 1$ & $0, Y r$ & r & ض & \\
\hline & $\cdot, \varepsilon \Gamma$. & •,VTr & $0 \wedge$ & $1, \wedge 9$ & 0,71 & M & ت & \multirow{2}{*}{ صفحة العنوان } \\
\hline & & & & $1,7 \varepsilon$ & $0, Y \leq$ & r & ض & \\
\hline & $\cdot, 70 \leqslant$ & •, $\leqslant$ \&. & $0 \wedge$ & $1,1 \%$ & $\bullet, V$. & r & ت & \multirow{2}{*}{ المتن } \\
\hline & & & & 1,7 . & $0, Y_{7}$ & r & ض & \\
\hline & - , \& Yq & $\cdot, \vee \wedge$. & $0 \wedge$ & $1, Y \leq$ & $0,0 \leq$ & r & ت & \multirow{2}{*}{ الرسوم والصور } \\
\hline & & & & 1,70 & $0, Y q$ & r & ض & \\
\hline & •,VTr & $\cdot, r \leq \varepsilon$ & $0 \wedge$ & $1, v$. & $\bullet, \wedge \bullet$ & M & ت & \multirow{2}{*}{ الألموان } \\
\hline & & & & 1,01 & 0,17 & r & ض & \\
\hline & • , TrV & $\cdot, \leqslant \diamond \wedge$ & $0 \wedge$ & $1, \varepsilon$. & 0,91 & r & ت & \multirow{2}{*}{ التجسيم } \\
\hline & & & & $1, \wedge r$ & $0, \leqslant \varepsilon$ & r & ض & \\
\hline & $\cdot, \varepsilon \leqslant \mu$ & $\cdot, \vee \wedge \diamond$ & $0 \wedge$ & 1,79 & $\bullet, \wedge \wedge$ & r & ت & \multirow{2}{*}{ الفراغ } \\
\hline & & & & $1, \varepsilon r$ & $0,1 V$ & r & ض & \\
\hline \multirow[t]{2}{*}{ غير دالة } & $\cdot,\{r \mid$ & $\cdot, \wedge \circ 4$ & $\Delta \wedge$ & $\Gamma, \varepsilon \wedge$ & 00,9 . & r & $ت$ & \multirow{2}{*}{ المقياس ككل } \\
\hline & & & & $r, r r$ & $0 \leq, \mu$ & ו & ض & \\
\hline
\end{tabular}


يتضح من الجدول السابق عدم وجود فــرق ذو دلالــة إحـصـائية بــين

متوسطي درجات المجمو عة التجريية و المجمو عة الضابطة في مقياس تـصميم

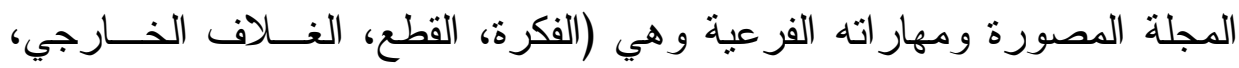

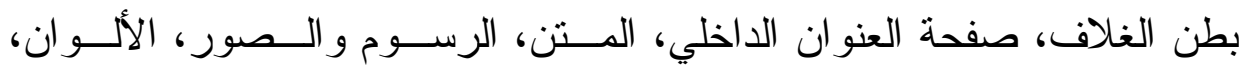

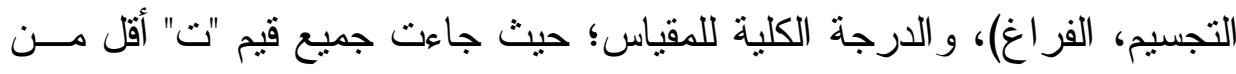
القيمة الجدولية حيث "ت " الجدولية (عند مستوي ه. ., •) ودرجات حريــة (01)

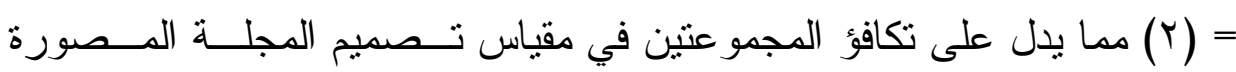
القبلي.

\section{• إحصاء قبلي بطاقة الملاحظة:}

التأكد من تكافؤ المجموعتين في بطاقة الملاحظة:

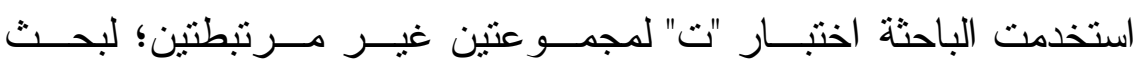

دلالة الفرق بين متوسطي درجات كل من المجموعة التجرييية و الــضابطة فـي

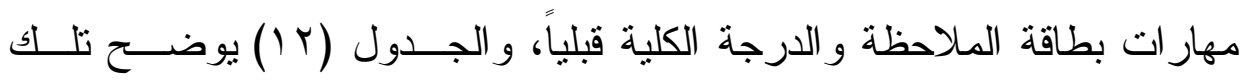

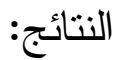




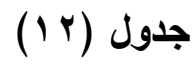

قيمة "ت" ودلالتها الإحصائية للفروق بين متوسطي درجات كل من المجموعة التجريبية و المجموعة الضابطة في مهارات بطاقة الملاحظة والارجة الكلية قبلياً

\begin{tabular}{|c|c|c|c|c|c|c|c|c|}
\hline مستوي الالاكة & الدلالة & $ت$ & ح.د & $\varepsilon$ & r & ن & مجموعتا & مهار الملاحظة بطاقة \\
\hline \multirow[t]{2}{*}{ غير دالة } & .,,$Y$. & ג צ", & $0 \wedge$ & $\vee, \vee \wedge$ & IV,Yr & $r$. & $ت$ & \multirow{2}{*}{ تخطيط المجلة } \\
\hline & & & & $\Lambda, 7 Y$ & $17, V r$ & $r$. & ض ض & \\
\hline \multirow[t]{2}{*}{ غير دالة } & $\cdot, r \vee v$ & $\cdot, r \wedge V$ & $\bullet \wedge$ & 0,00 & $1 \wedge, \wedge \vee$ & $r$. & $ت$ & \multirow{2}{*}{ تنفيذ المجلة } \\
\hline & & & & 7,1 . & $1 \wedge, 74$ & $r$. & ض & \\
\hline \multirow[t]{2}{*}{ غير دالة } &., 91. & $\cdot, r \wedge q$ & $\bullet \wedge$ & $\varepsilon, 7$. & $1 \leq, 7$. & $r$. & ت & \multirow{2}{*}{ تقويم المجلة } \\
\hline & & & & $\varepsilon, 7 r$ & $1 \varepsilon, \mu$ & $r$. & ض & \\
\hline \multirow[t]{2}{*}{ غير دالة } & $\cdot, \leqslant 10$ & $\cdot, \varepsilon \ldots$ & $0 \wedge$ & 17,17 & $0, v$. & $r$. & ت & \multirow{2}{*}{ البطاقة ككل } \\
\hline & & & & $1 \leqslant, 09$ & $\leq 9,79$ & $r$. & ض & \\
\hline
\end{tabular}

يتضـح من الجدول السابق عدم وجود فــرق ذو دلالـــة إحــصائية بــين متوسطي درجات المجموعة التجريبية و المجموعة الــضـابطة فـــي المهـــار ات المتضمنة ببطاقة الملاحظة وهي (مهارة تخطيط المجلة المصورة، تتفيذ المجلــة المصورة، تقويم المجلة المصورة)، و الدرجة الكلية للبطاقة؛ حيث جاءت جميـع قيم "ت" أقل من القيمة الجدولية حيث "ت " الجدوليــة (عنــد مسستوي 0 .,. )

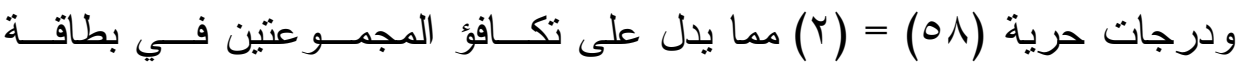

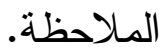

$$
\text { 7) التطبيق البعدي لأدوات البحث: }
$$

عقب الانتهاء من التدريس للمجمو عتين التجريبية و الضـابطة، تم تطبيــق أدوات البحث المتمثلة في مقياس تصميم المجلة المــصورة لمهــار ات التعـايش وبطاقة ملاحظة أداء الطالبة المعلمة تطبيقا بعديا على الطالبات عينــة البحـــ، وذللك بهدف تحديد الدرجة الكلية البعدية لأداء الطالبات المعلمات عينة الدر اســـة 
على المقياس وبطاقة الملاحظة مع مر اعاة أن يكون التطبيق البعدي فــي نفـس ظروف وشروط التطبيق القبلي.

\section{نتائج البحث ومناقشتها}

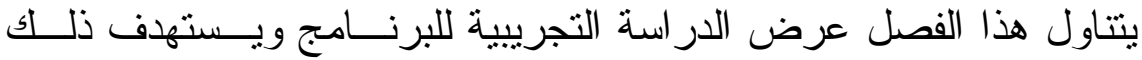

البحث فياس فاعلية برنامج تدريبي للطالبة المعلمة لتصميم المجلــة المــصورة

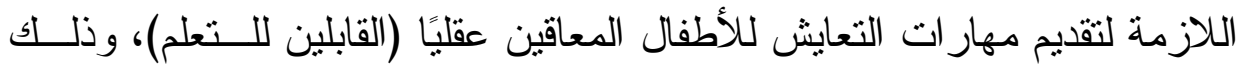
من خلال عرض نتائج البحث التجريبية ومناقشتها. أولا: نتائج الاراسة التجريبية: التتائج الخاصة بمقياس تصميم المجلة المصورة لمهارات التعايش: للتحقق من صحة الفرض الأول الأي ينص علي: يوجد فرق ذو دلالة إحصائية عنـــ مسستوي (ه . , • ) بــين متوســطي درجات طالبات المجموعتين (التجريبية والضابطة) في التطبيق البعدي لمقياس المجلة المصورة لمهار ات التعايش لصالح المجموعة التجريبية التـي درســ بالبرنامج المقترح.

وقد استخدمت الباحثة اختبار "ت" لمجموعتين غير مسـرتبطنين؛ لبحــث دلالـــة الفرق بين متوسطي درجات كل من المجموعة التجريبية و المجموعة الـضـابطة فــي

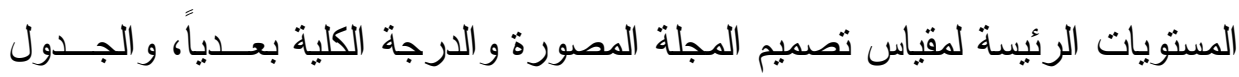

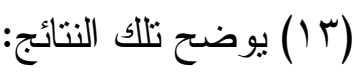

المجلد الخامس rr




$$
\text { جدول (ir) }
$$

قيمة "ت" ودلالتها الإحصائية للفروق بين متوسطي درجات كل من المجموعتين (التجريبية

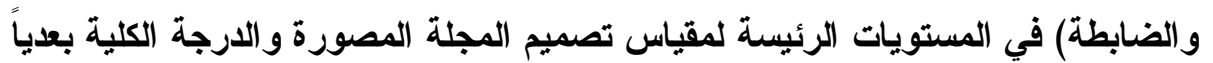

\begin{tabular}{|c|c|c|c|c|c|c|c|}
\hline الالاية & $ت$ & ح.د & $\varepsilon$ & p & ن & مجموعتا البحث & مستويات مقياس \\
\hline \multirow[t]{2}{*}{ 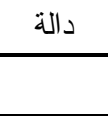 } & $I Y, V V$ & $0 \wedge$ & $\cdot, \leqslant \vee$ & $1 \cdot, v \cdot$ & r & $ت$ & \multirow{2}{*}{ الفكرة } \\
\hline & & & $r, \cdot 1$ & 0,9 . & r & ض & \\
\hline \multirow[t]{2}{*}{ 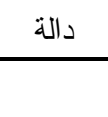 } & 11 & $0 \wedge$ & $\cdot, \varepsilon r$ & $9, r$. & M & ت & \multirow{2}{*}{ القطع } \\
\hline & & & 1,91 & $\varepsilon,{ }^{\prime}$ & ו & ض & \\
\hline \multirow[t]{2}{*}{ 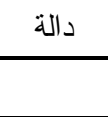 } & $11, \leqslant 7$ & $0 \wedge$ & $\cdot$, to & $9, \leqslant 0$ & 蒋 & ت & \multirow{2}{*}{ الغلاف الخارجي } \\
\hline & & & I,VY & $0,1 \pi$ & M & ض & \\
\hline \multirow[t]{2}{*}{ 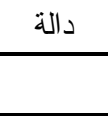 } & $11, r v$ & $0 \wedge$ & $\cdot, 7$ & 11,1 & r & $ت$ & \multirow{2}{*}{ بطن الغلاف } \\
\hline & & & 1,9 & $\uparrow, \vee$. & M & ض & \\
\hline \multirow[t]{2}{*}{ 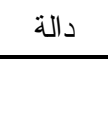 } & $M, \wedge q$ & $0 \wedge$ & $\cdot, \Gamma \wedge$ & 9,^r & r & $ت$ & \multirow{2}{*}{ صفدة العنوان الداخلي } \\
\hline & & & $1, \wedge \varepsilon$ & $7, \cdot V$ & I & ض ض & \\
\hline \multirow[t]{2}{*}{ دالة } & $11,0 r$ & $0 \wedge$ & צוז, • & $9,9$. & ו & $ت$ & \multirow{2}{*}{ المتن } \\
\hline & & & $r, \cdot r$ & $\varepsilon, \cdot r$ & M & ض & \\
\hline \multirow[t]{2}{*}{ د الة } & Ir,r. & $0 \wedge$ & $\cdot, r q$ & $৭, \wedge \vee$ & ו & $ت$ & \multirow{2}{*}{ الرسوم و الصور } \\
\hline & & & Y, r & $\varepsilon, r$ & M & ض ض & \\
\hline \multirow[t]{2}{*}{ 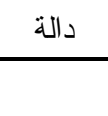 } & $11,0 \mathrm{r}$ & $0 \wedge$ & $\cdot,\{1$ & $9, \wedge r$ & r & $ت$ & \multirow{2}{*}{ الألوان } \\
\hline & & & $r, I r$ & $\varepsilon, r q$ & ו & ض ض & \\
\hline \multirow[t]{2}{*}{ دالة ل } & $11, \leqslant 7$ & $0 \wedge$ &., 01 & $1 \cdot, 0$ & ו & $ت$ & \multirow{2}{*}{ التجسيم } \\
\hline & & & $r, 1 \varepsilon$ & 0,9 . & r & ض & \\
\hline \multirow[t]{2}{*}{ دالة ل } & $M, \cdot r$ & $0 \wedge$ & $\cdot, \leqslant 9$ & $1 \cdot, 99$ & M & $ت$ & \multirow{2}{*}{ الفراغ اغ } \\
\hline & & & $r, \cdot \leq r$ & $\varepsilon, \vee q$ & M & ض ض & \\
\hline \multirow[t]{2}{*}{ دالة } & I & $\Delta \wedge$ & •,Ar & $1,1, \leq 7$ & M & ت & \multirow{2}{*}{ المقياس ككل } \\
\hline & & & 0,90 & $01, \leqslant r$ & M & ض & \\
\hline
\end{tabular}


يتضح من الجدول السابق وجود فرق ذو دلالة إحصائية بــين متوســـي

درجات المجمو عة التجرييية و المجموعة الــضابطة فــي المـستويات الرئيسـسة للمقياس و الارجة الكلية للمقياس؛ حيث جاءت جميع قيم " ت" أكبر مــن القيمـــة

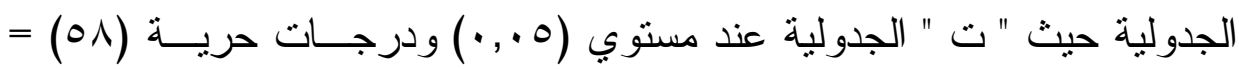

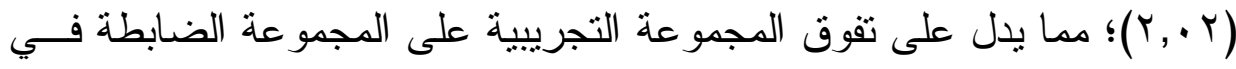

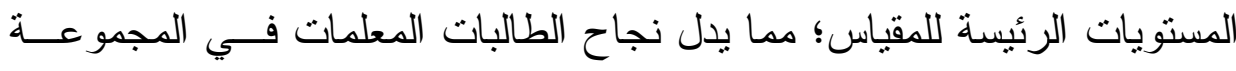
التجريبية على تصميم المجلة المصورة لمهار ات التعايش لدى الأطفال المعـاقين عقليا القابلين للتعلم. ويوضح الثنكل التالي (شكلب) التمثنيل البياني للفـرق بــين متوســات

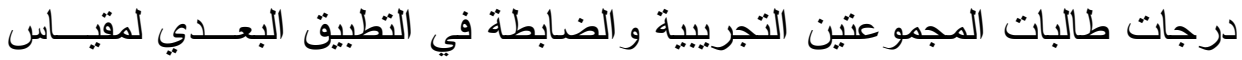
تصميم المجلة المصورة لمهارات التعايش لدى الأطفال المعاقين عقليا القـابلين للتعلم ككل وفي مستوياته الرئيسة.

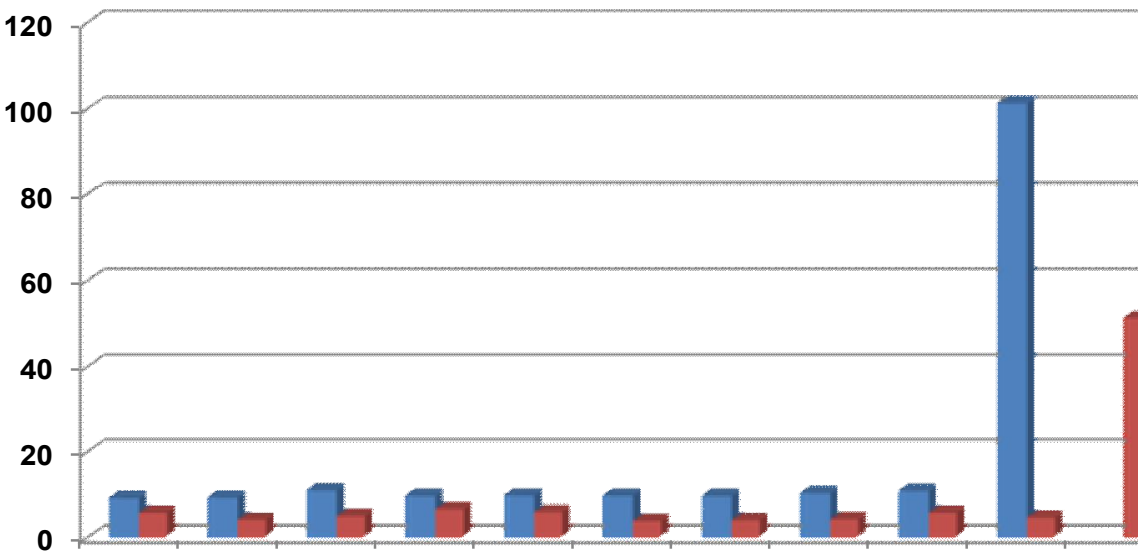

شكل (r) التمثيل البياني للفرق بين متوسطات درجات طالبات المجموعتين (التجريبية و الضابطة) في التطبيق البعدي لمقياس تصميم المجلة المصورة ككل ومستوياته الرئيسة 
وفي ضوء تللك النتيجة، يمكن قبول الفرض الأول من فـروض البحــث

يوجد فرق ذو دلالة إحصائية عنـــ مسستوي (0 + , •) بـين متوســـي درجات طالبات المجموعتين (التجريبية والضابطة) في التطبيق البعدي لمقياس المجلة المصورة لمهار ات التعايش لصالح المجموعة التجريبية التــي درســـ بالبرنامج المقترح.

مقارنة نتائج التطبيق القبلي بالبعدي للمجموعة التجريبية في مقياس تصميم المجلة المصورة لمهارات التعايش: ولاختبار الفرض الثاني الذي ينص علي: يوجد فرق ذو دلالة إحصائية عند مستوي (ه ، , •) بــين متوســي درجـات طالبات (المجموعة التجريبية) في التطبيقين (القبلي والبعدي) لمقياس المجلـة المصورة لصالح التطبيق البعدي.

استخدمت الباحثة اختبار "ت" للمجموعات المرتبطة لبحث دلالة الفرق بين متوسطي درجات كل من التطبيقين (القبلي و البعدي) للمجمو عة التجريبيــة فـي المستويات الرئيسة لمقياس تصميم المجلة المصورة و الدرجة الكليــة، و الجــدول ( ) ( ) يوضح تلك النتائج: 
جدول (؛ 1 ) قيمة "ت" ودلالتها الإحصائية للفروق بين متوسطي درجات كل من

التطبيقين (القبلي والبعدي) للمجموعة التجريبية في المستويات الرئيسة

لمقياس المجلة المصورة و الدرجة الكلية

\begin{tabular}{|c|c|c|c|c|c|c|c|}
\hline مستوي & 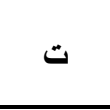 & $\tau . د$ & $\varepsilon$ & $p$ & ن & مجموعتا & مستويات مقياس \\
\hline \multirow{2}{*}{ دالة } & \multirow{2}{*}{$1 \varepsilon, Y v$} & \multirow{2}{*}{ rq } & $r, .1$ & 0,9 . & ri & قبلي & \multirow{2}{*}{ الفكرة } \\
\hline & & & $\cdot, \varepsilon V$ & $1,, v$. & $r_{1}$ & بعدب & \\
\hline \multirow{2}{*}{ دالة دالة } & \multirow{2}{*}{14} & \multirow{2}{*}{ rq } & 1,91 & $\varepsilon, \pi r$ & ri & 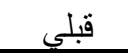 & \multirow{2}{*}{ القطع } \\
\hline & & & $\cdot, \varepsilon r$ & $9, r$. & $r_{1}$ & بعدي & \\
\hline \multirow{2}{*}{ دالة } & \multirow{2}{*}{$14, \Sigma 4$} & \multirow{2}{*}{ rq } & $1, V T$ & $0,1 \pi$ & $r$ & قبلي & \multirow{2}{*}{ الغلاه الخارجي } \\
\hline & & & . ro & $9, \leqslant 0$ & $r$ & بعدب & \\
\hline \multirow{2}{*}{ 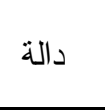 } & \multirow{2}{*}{$\mid r, r v$} & \multirow{2}{*}{ rq } & 1,9 . & $7, \vee \cdot$ & ri & قبلي & \multirow{2}{*}{ بطن الغلاف } \\
\hline & & & $\cdot, \pi$ & 11,1 & ri & بعدي & \\
\hline \multirow{2}{*}{ دالة } & \multirow{2}{*}{$1 \varepsilon, \wedge 9$} & \multirow{2}{*}{ rq } & $1, \wedge \varepsilon$ & $7, \cdot V$ & $r$ & قبلى ل & \multirow{2}{*}{ صفحة العنوان } \\
\hline & & &.,$\Gamma \wedge$ & $9, \lambda r$ & $r$ & بعدب & \\
\hline \multirow{2}{*}{ دالة } & \multirow{2}{*}{$1 r, 0 \mathrm{r}$} & \multirow{2}{*}{ rq } & $r, \cdot r$ & $\varepsilon, \cdot r$ & $r$ & قبلي & \multirow{2}{*}{ المتن } \\
\hline & & & 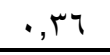 & 9,9 . & $r$ & بعدي & \\
\hline \multirow{2}{*}{ دالة } & \multirow{2}{*}{$1 \varepsilon, r}$. & \multirow{2}{*}{ rq } & $r, Y Y$ & $\varepsilon, r$. & $r$ & قبلي & \multirow{2}{*}{ الرسوم والصور } \\
\hline & & & 年, & $9, \wedge \mathrm{V}$ & ri & بعدي & \\
\hline \multirow{2}{*}{ دالة } & \multirow{2}{*}{ 1r,or } & \multirow{2}{*}{ rq } & $r, I Y$ & $\varepsilon, r q$ & $r$ & قبلي & \multirow{2}{*}{ الألوان } \\
\hline & & & $\cdot, \varepsilon 1$ & $9, \wedge Y$ & ri & بعدي & \\
\hline \multirow{2}{*}{ دالة } & \multirow{2}{*}{$1 T, \leqslant T$} & rg & $r, 1 \varepsilon$ & 0,9 & $r$ & قبلي ي & 1الت-7) \\
\hline & & &., 01 & $1 \cdot, 0$. & $r$ & بعدي & تجنجير \\
\hline دالة & $1 \leqslant \cdot r$ & rq & $r, \cdot \leq 4$ & $\varepsilon, \vee 9$ & $r$ & قبلى & الف اغ \\
\hline & 16,1 & & $\cdot, \leqslant 9$ & $1 ., 99$ & $r$ & بعدي & العراخ \\
\hline لمالمة & (1) & Ya & 0,90 & $01, \leqslant \mu$ & $r$ & قبلي & «s lon \\
\hline (1) & $\pi, \pi T$ & 14 & . Ar & $1.1, \leqslant 4$ & $r_{1}$ & بعدي & المعياس ككل \\
\hline
\end{tabular}

يتضح من الجدول السابق وجود فرق ذو دلالة إحصائية بـين متوســـي الني

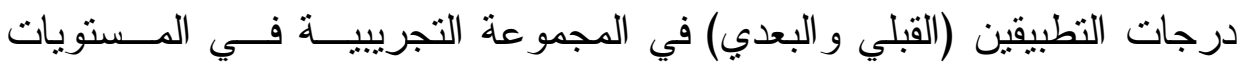


الرئيسة لمقياس تصميم المجلة المصورة و الدرجة الكلية للمقياس؛ حيث جـاءت

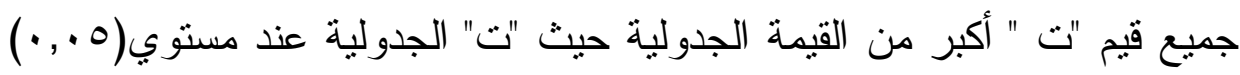
ودرجات حرية (rq) = (r, (r.0) مما يعني حدوث نمو في مقياس تصميم المجلة

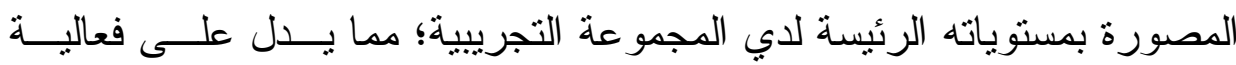
المعالجة التجرييية في تتمية مهار ات تصميم المجلة المصورة. ويوضح الثكل النالي التمثيل البياني للفرق بين منوسطات درجات طالبات

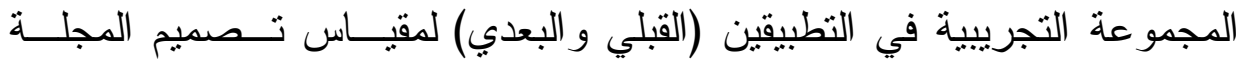
المصورة ككل وفي مستوياته الرئيسة.

شكل (r) (ب)

التمثيل البياني للفرق بين متوسطات درجات طالبات المجموعة التجريبية في التطبيقين (القبلي و البعدي) لمقياس تصميم المجلة المصورة ومهاراته الرئيسة 
وفي ضوء تلك النتائج، يمكن قبول الفرض الثاني من فروض البحث وهو:

يوجد فرق ذو دلالة إحصائية عنـــ مسستوي (ه . , • ) بـين متوســـي

درجات طالبات (المجموعة التجريبية) في التطبيقين (القبلي والبعدي) لمقياس المجلة المصورة لصالح التطبيق البعدي.

ـ فعالية المعالجة التجريبية في تنمية مهارات تصميم المجلة المصورة (حجم التأثير): لتحديد فعالية المعالجة التجريبية في تنمية مهار ات تصميم المجلة المصورة، قامت الباحثة باستخدام معادلة (خ) لتحديد حجم تأثير المعالجة في تتمية كل مستوي رئيسي من مستويات المقياس، وكذلك الدرجة الكلية اعتماداً على قيمة "ت" المحسوبة عند تحديد دلالة الفروق بين التطبيقين (القبلي و البعدي) للمجموعة التجريبية، و الجدول (ع ا) يوضح ذلك:

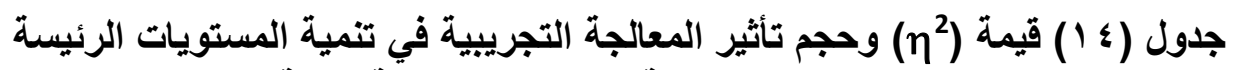

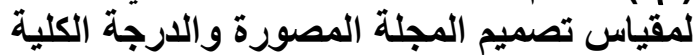

\begin{tabular}{|c|c|c|c|}
\hline حجم التأثير & $\eta^{2}$ & $ت$ & المستويات الرئيسة لمقياس المجلة المصورة \\
\hline كبيز & $\cdot, \wedge \wedge$ & $I \leqslant, V V$ & الفكرة \\
\hline كبيز &., 9 & 14 & القطع \\
\hline كبيز & $\cdot, \wedge \theta$ & $1 \%, \leq 7$ & الغلاف الخارجي \\
\hline كبيز & $\cdot, \wedge \vee$ & $I r, \mu v$ & بطن الغلاف \\
\hline كبير &., $9 \leq$ & $1 \leqslant, \wedge 9$ & صفحة العنوان الداخلي \\
\hline كبير & $\cdot, \wedge r$ & Ir,Or & المتن \\
\hline كبير & $\cdot, \wedge 9$ & $1 \leq, r$. & الرسوم والصور \\
\hline كبيز & $\cdot, \Lambda \mathrm{r}$ & Ir,or & الألوان \\
\hline كبير & $\cdot, \wedge \uparrow$ & 14,84 & 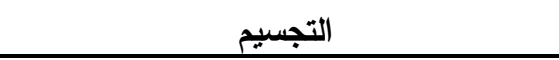 \\
\hline كبيز & $\cdot, 9 r$ & $1 \varepsilon, \cdot r$ & 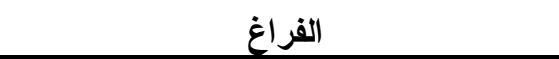 \\
\hline كبير & $\cdot, \wedge \wedge$ & $1 \Lambda, Y r$ & المقياس ككل \\
\hline
\end{tabular}




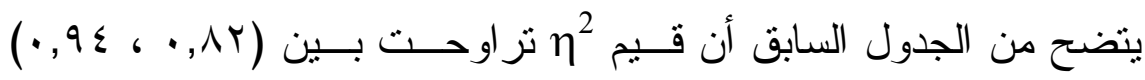
لمستويات تصميم المجلة الرئيسة للمقياس، وبلغت قيمتها (^ᄉ, • ) للارجة الكلية؛ مما يعني أن المعالجة التجريبية تسهم في التباين الحادث في المستويات الرئيسة

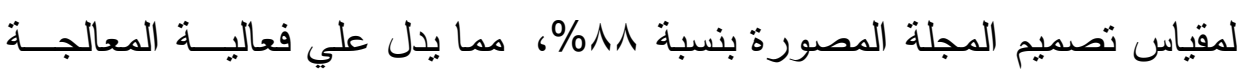
التجريبية في تتمية المستويات الرئيسة لمقياس تصميم المجلة لــدي المجموعـــة - التجريبية

\section{النتائج الخاصة ببطاقة ملاحظة:}

$$
\text { تم التحقق من صحة الفرض الثالث الأي ينص علي: }
$$

يوجد فرق ذو دلالة إحصائية عنـــ مسستوي (ه . , • ) بــين متوســطي درجات طالبات المجموعتين (التجريبية والضابطة) في التطبيق البعدي لبطاقـة

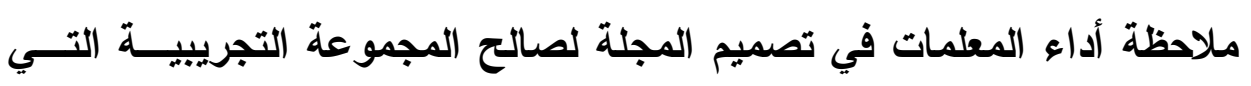
درست بالبرنامج المقترح.

استخدمت الباحثة اختبار "ت" لمجمو عتين غير مرتبطتين؛ لبحــث دلالـــة الفرق بين متوسطي درجات كل من المجموعة التجريبية و المجموعة الــضابطة في المهار ات الرئيسة لبطاقة الملاحظة و الدرجة الكلية بعـدياً، و الجــدول (10) يوضح نلاك النتائج: 


\section{جدول (10)}

قيمة "ت" ودلاتهها الإحصائية للفروق بين متوسطي درجات كل من المجموعتين (التجريبية والضابطة) في المهارات الرئيسة لبطاقة الملاحظة و الارجة الكلية بعدياً

\begin{tabular}{|c|c|c|c|c|c|c|c|}
\hline مستوي & 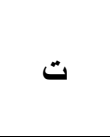 & ح.د & $\varepsilon$ & P & ن & مجموعتا & مهارات بطاقة \\
\hline \multirow{2}{*}{ دالة } & \multirow{2}{*}{$q, r q$} & \multirow{2}{*}{01} & $0, V Y$ & $r \cdot, 9 r$ & ri & $ت$ & \multirow{2}{*}{ تخطيط المجلة } \\
\hline & & & $\checkmark, \wedge 0$ & $10,4 \pi$ & ri & ض ض & \\
\hline \multirow{2}{*}{ دالة } & \multirow{2}{*}{$V, O Y$} & \multirow{2}{*}{$0 \wedge$} & $\checkmark, Y \wedge$ & $r \cdot, \Delta v$ & ri & 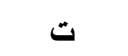 & \multirow{2}{*}{ تنفيذ المجلة } \\
\hline & & & 0,00 & 11 & ri & ض ض & \\
\hline \multirow{2}{*}{ دالة } & \multirow{2}{*}{$1 \%, 9}$. & \multirow{2}{*}{01} & 0,19 & $\curlyvee \wedge, q \vee$ & ri & $ت$ & \multirow{2}{*}{ تقويم المجلة } \\
\hline & & & $r, 90$ & . & ri & ض & \\
\hline \multirow{2}{*}{ دالة } & \multirow{2}{*}{ דוז,r } & \multirow{2}{*}{$0 \wedge$} & $1 \%, q \leqslant$ & $q_{.,, \leqslant v}$ & ri & $ت$ & \multirow{2}{*}{ البطاقة ككل } \\
\hline & & & $\mid r, 11$ & $\varepsilon V, Y T$ & ri & ض & \\
\hline
\end{tabular}

يتضح من الجدول السابق وجود فرق ذو دلالة إحصائية بـين منوســـي الئي درجات المجموعة التجريبية و المجموعة الضابطة في المهار ات الرئيسة لبطاقـــة

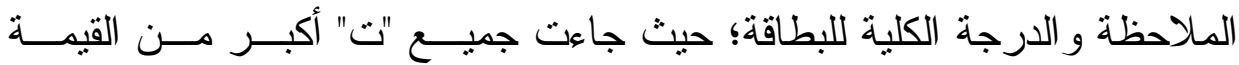

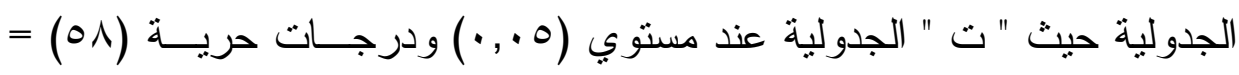

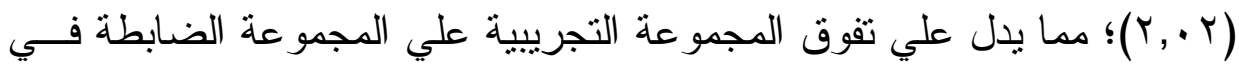

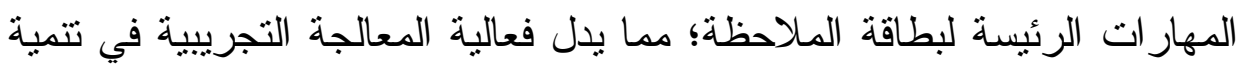
الجانب الأدائي لمهارات تصميم المجلة المصورة لمهار ات التعـايش للأطفــال المعاقين عقليا القابلين للتعلم لدي المجموعة التجريبية. 
ويوضـح الثكل التالي (شكل ع) التثنيل البياني للفـرق بـين متوســـات

درجات طالبات المجمو عتين التجريبية و الضـابطة في التطبيق البعــدي لبطاقــة الماحظة ككل وفي مهار اتها الرئيسة.

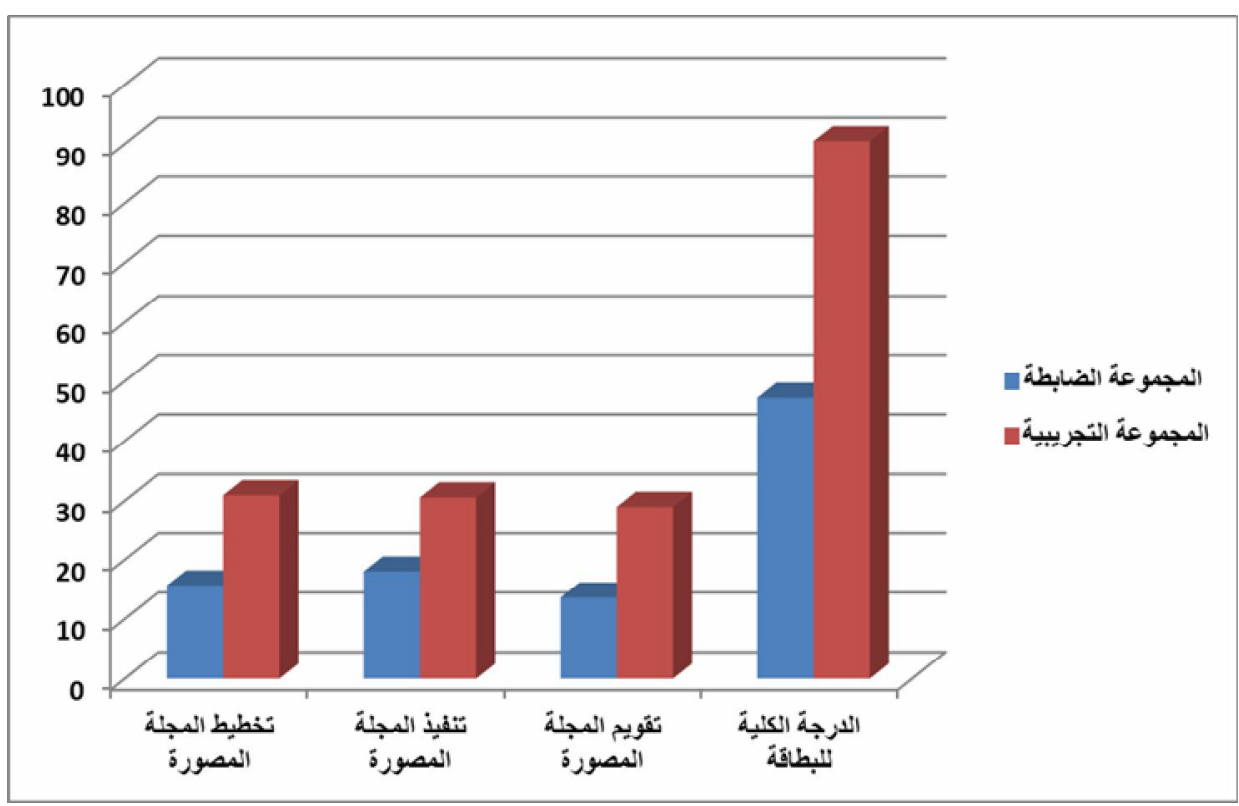

شكل (๕) ( )

التمثيل البياني للفرق بين متوسطات درجات طلاب المجموعتين (التجريبية والضابطة) في التطبيق البعدي لبطاقة الملاحظة ككل ومهار اتها الرئيسة

وفي ضوء تلك النتيجة، يمكن قبول الفرض الثالث من فروض البحث

يوجد فرق ذو دلالة إحصائية عند مستوي (0., (•) بين متوسطي درجات طالبات المجموعتين (التجريبية والضابطة) في التطبيق البعدي لبطاقة ملاحظة أداء المعلمات في تصميم المجلة لصالح المجموعة التجريبية التي درست بالبرنامج المقترح. 
• مقارنة نتائج التطبيق القبلي بالبعدي للمجموعة التجريبية في بطاقة الملاحظة: - مانة

$$
\text { و لاختبار الفرض الرابع الذي ينص علي: }
$$

يوجد فرق ذو دلالة إحصائية عنــد مستستوي (ه •، •) بـين متوسـطي

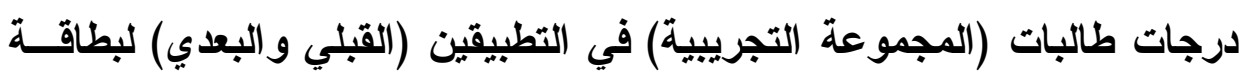
ملاحظة أداء المعلمات في تصميم المجلة لصالح التطبيق البعدي. استخدم الباحث اختبار "ت" للهجموعات المرتبطة لبحث دلالة الفرق بـين

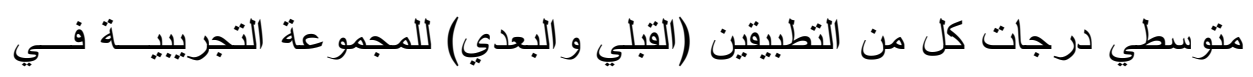

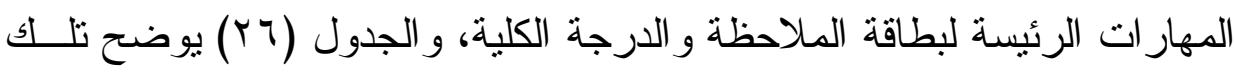

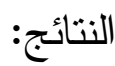

$$
\text { جدول (Y ) }
$$

قيمة "ت" ودلالتها الإحصائية للفروق بين متوسطي درجات كل من التطبيقين (القبلي

\begin{tabular}{|c|c|c|c|c|c|c|c|}
\hline مستوي & $ت$ & ح.د & $\varepsilon$ & b & $\dot{0}$ & القياس & مهار ات بطاقة \\
\hline \multirow{2}{*}{ 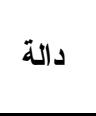 } & \multirow{2}{*}{$\wedge, r \wedge \wedge$} & \multirow{2}{*}{ rq } & $0, V Y$ & $r \cdot, 9 r$ & M & بعدي بع & \multirow{2}{*}{ تخطيط المجلة المصورة } \\
\hline & & & $\curlyvee, \vee \wedge$ & $17, r r$ & r & قبلي & \\
\hline \multirow{2}{*}{ دالة } & \multirow{2}{*}{$\wedge, 1,0$} & \multirow{2}{*}{ rq } & $\vee, r \wedge$ & $r \cdot, o v$ & r & بعدي & \multirow{2}{*}{ تنفيذ المجلة المصورة } \\
\hline & & & $\varepsilon, 00$ & $I V, \wedge V$ & r & قبلي & \\
\hline \multirow{2}{*}{ 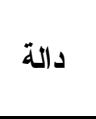 } & \multirow{2}{*}{$11, r 99$} & \multirow{2}{*}{ rq } & 0,19 & Y^,৭V & r & بعدي & \multirow{2}{*}{ تقويم المجلة المصورة } \\
\hline & & & r, & $1 \%, 7$. & r & قبلي & \\
\hline \multirow{2}{*}{ دالة } & \multirow{2}{*}{$I Y, \wedge \circ V$} & \multirow{2}{*}{ rq } & $1 Y, 9 \leq$ & $q \cdot, \leqslant \vee$ & r & بعدي بع & \multirow{2}{*}{ البطاقة ككل } \\
\hline & & & 14,17 & $\leq \vee, V$. & r & قبلي & \\
\hline
\end{tabular}
و البعدي) للججموعة التجريبية في المهارات الرئيسة لبطاقة الملاحظة و الدارجة الكلية 
يتضح من الجدول السابق وجود فرق ذو دلالة إحصائية بـين متوســي

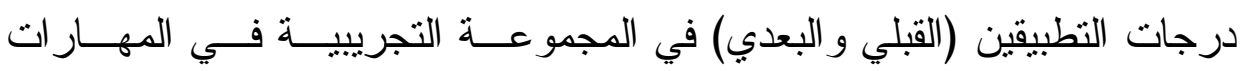

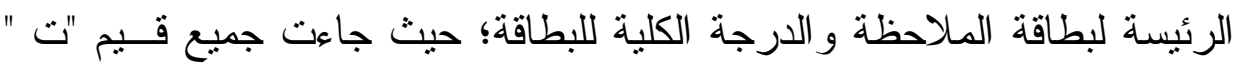

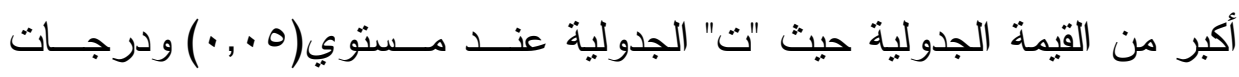

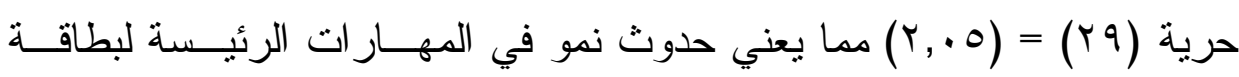

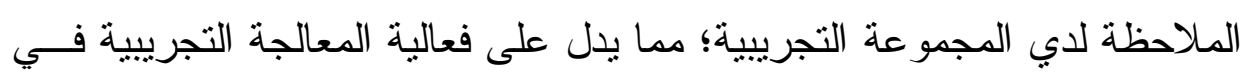

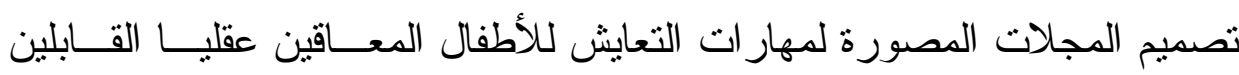
للتعلم. ويوضح الثكل النالي التمثيل البياني للفرق بين منوسطات درجات طالبات

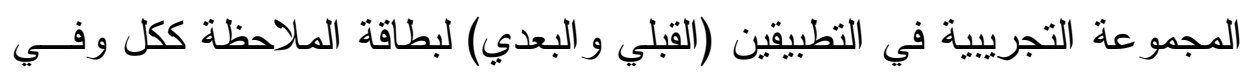

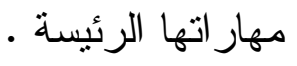

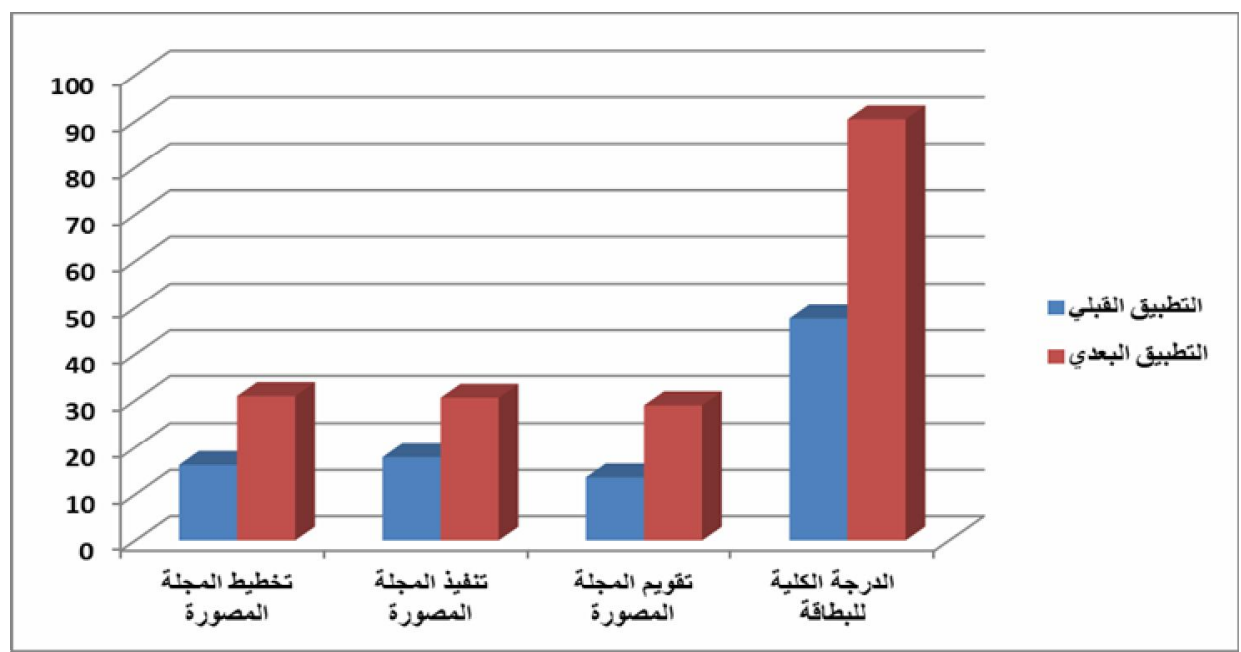

شكل (v)

التمثيل البياني للفرق بين متوسطات درجات طالبات المجموعة التجريبية في التطبيقين (القبلي والبعدي) لبطاقة الملاحظة ومهار اتها الرئيسة 
وفي ضوء تللك النتائج، يمكن قبول الفرض الر ابع من فروض البحث وهو:

يوجد فرق ذو دلالة إحصائية عند مستوي (0.05) بين متوسطي درجات

طالبات المجموعة التجريبية في التطبيقين (القبلي والبعدي) لبطاقة الملاحظــة لصالح التطبيق البعدي.

-فعالية المعالجة التجريبية في تنمية مهارات تصميم المجلات المصورة لمهارات التعايش (حجم التأثير):

لتحديد فعالية المعالجة التجريبية في تتمية تــميم المجــلات المـصورة

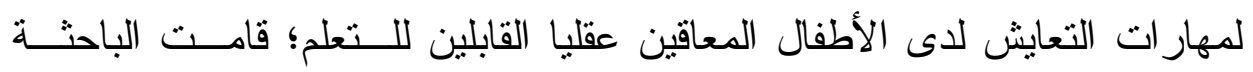
باستخدام معادلة (ך) لتحديد حجم تأثير المعالجة في تتمية كل مهارة رئيسة من مهار ات بطاقة الملاحظة، وكذلك الدرجة الكلية اعتماداً علي قيمة "ت" المحسوبة

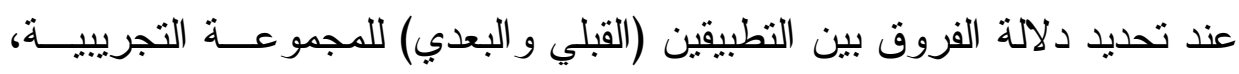
و الجدول (rV) يوضح ذلك:

$$
\text { جدول (rv) }
$$

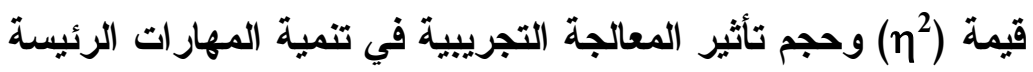
للبطاقة الملاحظة و الارجة الكلية

\begin{tabular}{|c|c|c|c|}
\hline حجم التأثير & $\eta^{2}$ & $ت$ & لمهارات الرئيسة لبطاقة الملاحظة \\
\hline كبير & $\cdot, \times)$ & $\Lambda, r q$ & تخطيط المجلة المصورة \\
\hline 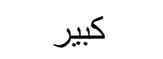 & $\cdot, 79$ & $\wedge, 11$ & تتفيذ المجلة المصورة \\
\hline 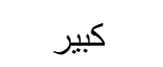 & $\cdot, \lambda r$ & $11, \varepsilon$. & تقويم المجلة المصورة \\
\hline 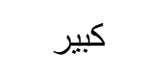 & $\cdot, \wedge 0$ & IY,人 & البطاقة ككل \\
\hline
\end{tabular}




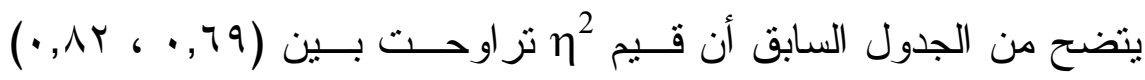

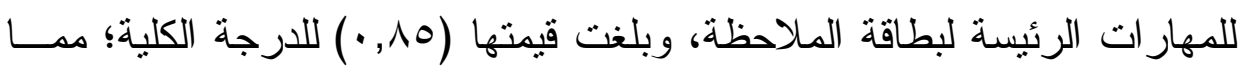

يعني أن المعالجة التجريبية تسهم في التباين الحادث فــي المهــار ات الرئيـــة لبطاقة الملاحظة بنسبة هر\%، مما يدل علي فعالية المعالجة التجريبية في تتمية الجانب الأدائي لمهار ات تصميم المجلات المصورة الرئيسة لبطاقـــة الملاحظــــة • لدي المجموعة التجريبية تحديد طبيعة العلاقة بين الجاتب المعرفي للطالبة المعلمة عن تصميم المجلات المصورة والجانب الأدي لتصميم تلك المجلات للأطفال المعاقين عقليا القابلين للتعلم : ليتم اختبار صحة الفرض الخامس من فروض البحث، والأي ينص علي : " توجد علاقة ارتباطية موجبة عنـــ مسستوي (0 +، •) بـين تحسـيل

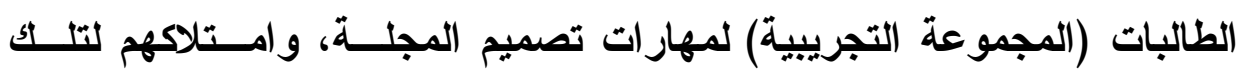
استخدمت الباحثة معادلة سييرمان بر اون؛ لحساب معامل ارتباط الرتـب؛ لتحديد طبيعة العلاقة بين الجانب المعرفي لتصميم المجلات المصورة و الجانــب الأدائي لتصميم تلك المجلات؛ و الجدول التالي يوضتح تلك النتائج: جدول(r^) معامل الارتباط بين الجانب المعرفي لتصميم المجلات المصورة والجاتب الأدائي لتصميم تلك المجلات.

\begin{tabular}{|c|c|c|}
\hline بطاقة الملاحظة & مقياس تصميم المجلات المصورة & المتغير ات \\
\hline & 1 & مقياس تصميم المجلات المصورة \\
\hline 1 & $* \cdot, \Sigma I r$ & بطاقة الملاحظة \\
\hline
\end{tabular}
(*) 
يتضح من الجدول السابق وجود علاقة ارتباطية موجبــة عنــــ مـستوي ه., • بين كل من الجانب المعرفي لتصميم المجلات المصورة و الجانب الأدائي

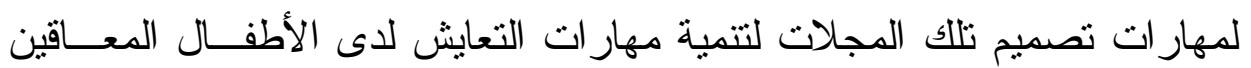
عقليا القابلين للتعلم.

\section{تفسير النتائج ومناقشتها:}

من النتائج التي سبق عرضها واختبار الفروض أمكن استتتاج ما يلي:

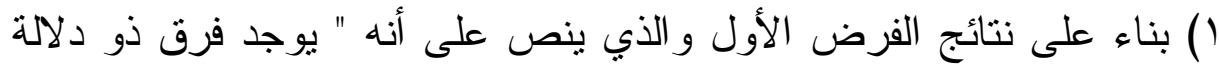
إحصائية عند مستوي (0., •) بين متوسطي درجات طالبات المجمو عتين (التجريبية و الضابطة) في النطبيق البعدي لكقياس المجلة المصورة لمهارات التعايش لصالح المجموعة التجريبية التي درست بالبرنامج المقترح" و التي أظهرت ارتفاع منوسط درجات المجموعة التجريبية

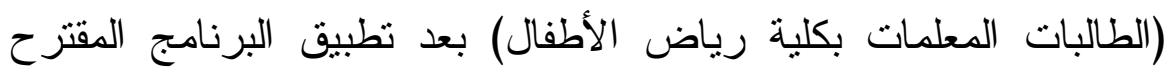

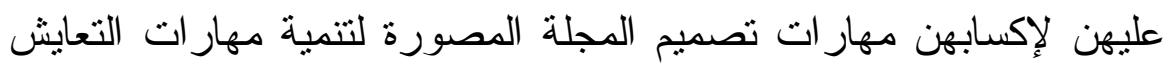
لدى الأطفال المعاقين عقليا القابلين للتعلم ، ويمكن تفسير هذه النتيجة و إرجاعها إلى الأسباب الأتية :

• تعريف الطالبات المعلمات بمهارات التعايش الواجب تتميتها لاى الأطفــال

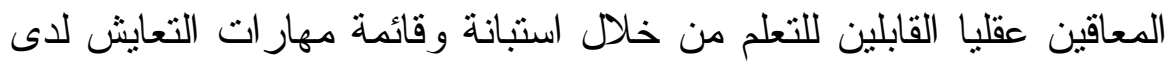

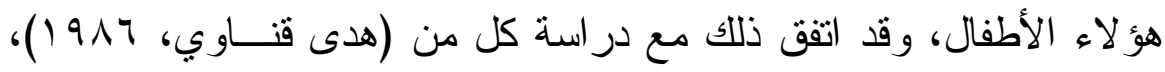

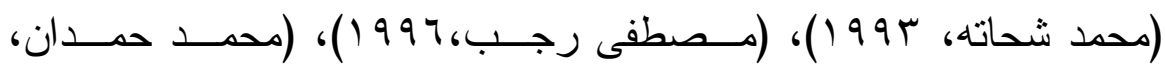

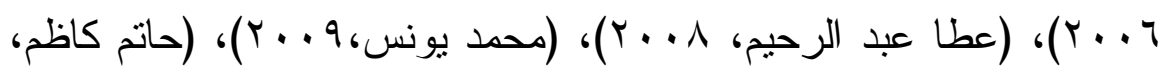
1)

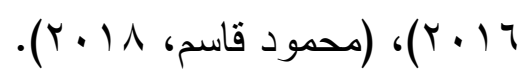


- استخدام مقياسا لمعرفة ددى إلمام الطالبات المعلمــات بمهـار ات تـصميم مجلات الأطفال المعاقين عقليا القابلين للتعلم ثم استخدام نفس المقياس بعـد الفابـ

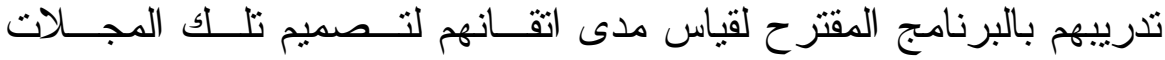

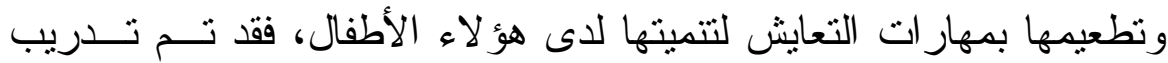

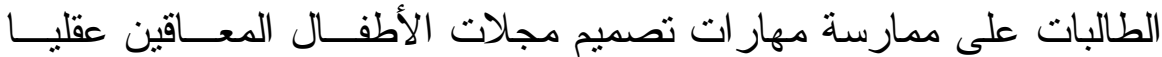

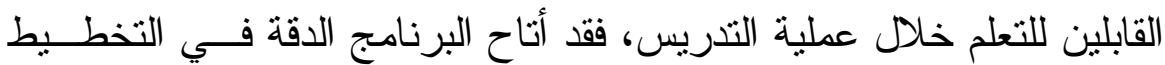

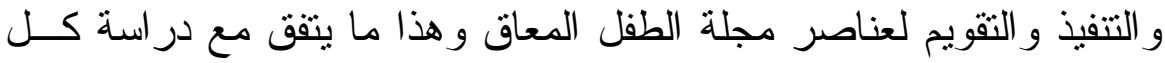

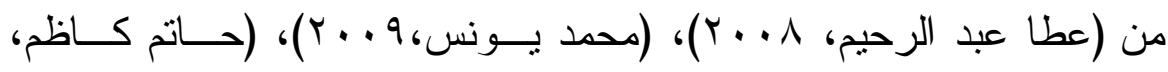

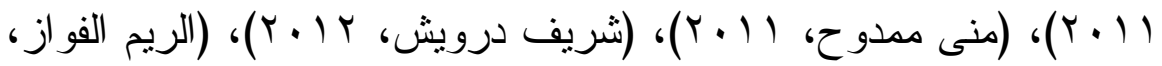

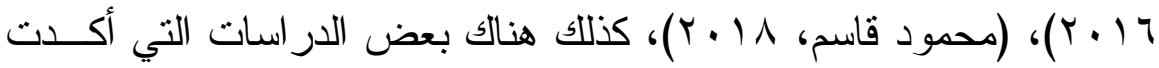

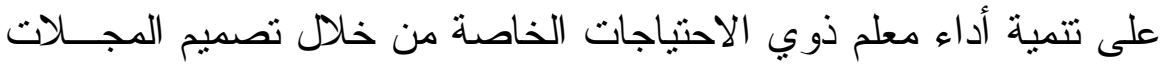

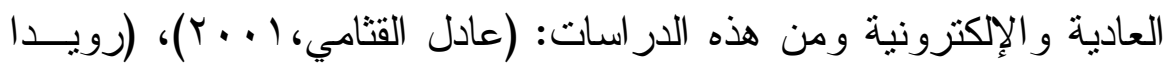

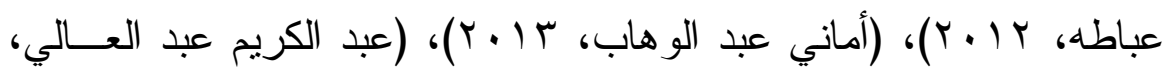

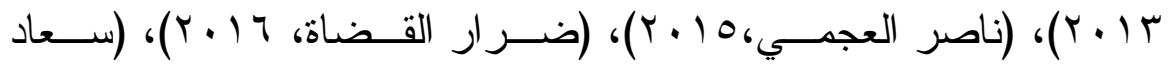

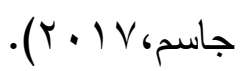

• اعتمد بناء وتصميم البرنامج المقترح على توظيف أنشطة مهار ات التعايش

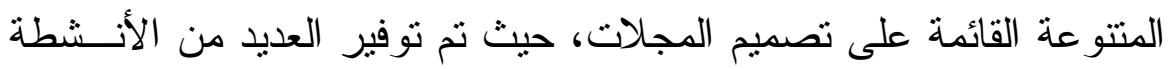
الفردية و الجماعية التي تتضمن في طياتها مهار ات التعايش اللازمة لتعلــيم

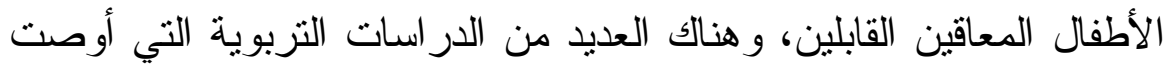

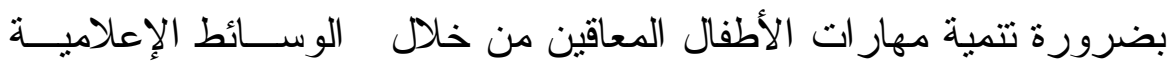

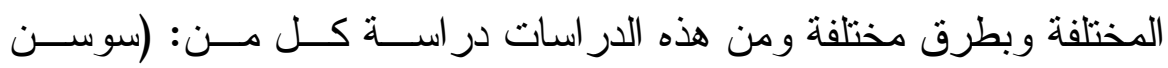

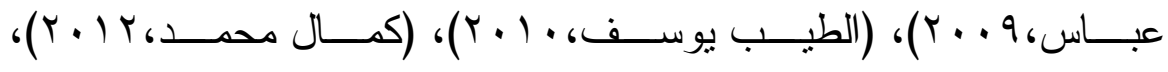




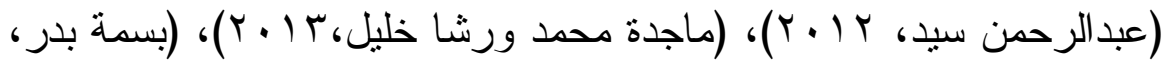

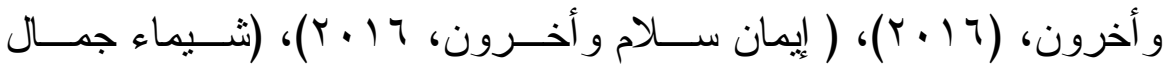

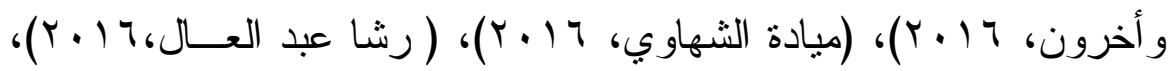

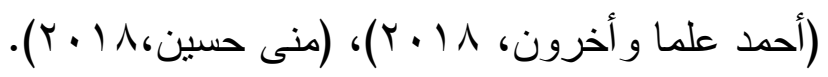
• قامت الطالبات المعلمات بتصميم المجلات المصورة للأطفال المعاقين عقليا

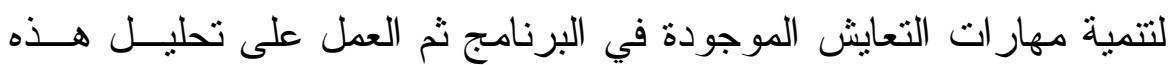
الأنشطة وتقويمها وطر ح التساؤ لات و إدارة مناقتشات بينها وبين أقر انها.

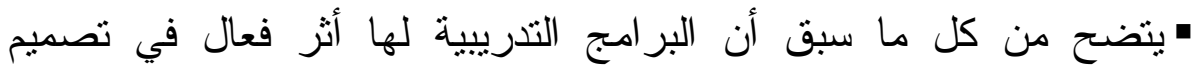

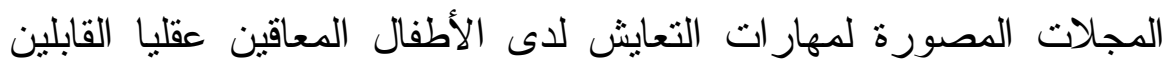
للتعلم. r) بناء على نتائج الفرض الثاني و الذي ينص على أنه " يوجد فرق ذو دلالة

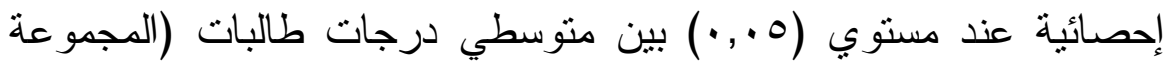

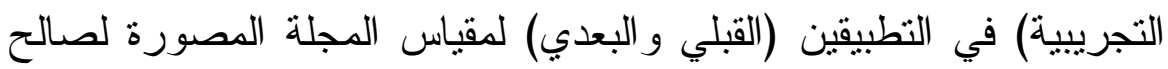
التطبيق البعدي" و التي أظهرت ارتفاع متوسط درجات المجموعة التجريبية (الطالبات المعلمات بكلية رياض الأطفال) بالنسبة لمقياس المجلات المصورة بعد تطبيق البرنامج المقترح لإكسابهن مهارات تصميم المجلات

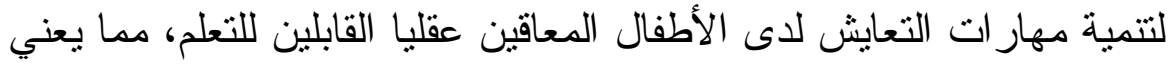
حدوث نمو في مقياس المجلات المصورة بمستوياته الرئيسة لدي المجموعة

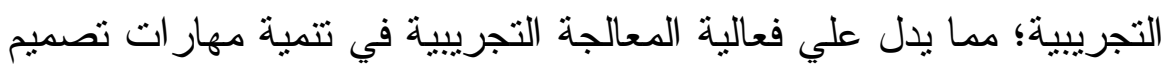

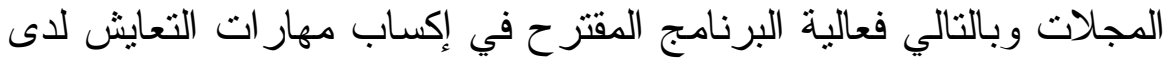
الأطفال المعاقين عقليا القابلين للتعلم، ومن ثم تحقيق البرنامج لأهدافهـ. 
r) بناء على نتائج الفرض الثالث و الذي ينص على أنه " يوجد فرق ذو دلالة

إحصائية عند مستوي (ه., •) بين متوسطي درجات طالبات المجمو عتين

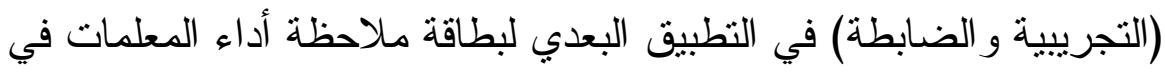

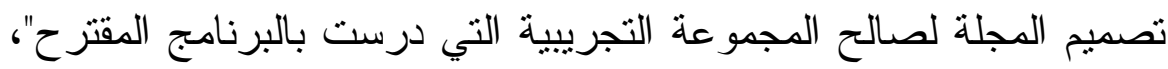
و التي أظهرت ارتفاع متوسط درجات المجموعة التجريبية (الطالبات

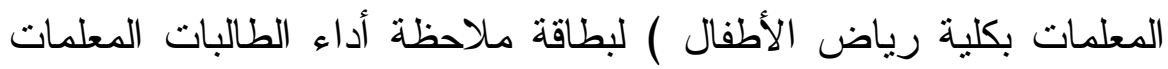
لمهار ات تصميم المجلات المصورة بعد تطبيق البرنامج المقتر ح لإكسابهن مهار ات التعايش اللازمة لتعليم الأطفال المعاقين عقليا.

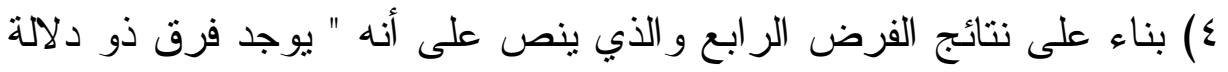
إحصائية عند مستوي (0.، •) بين متوسطي درجات طالبات (المجموعة

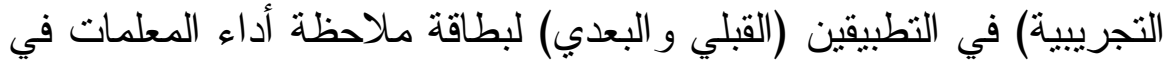

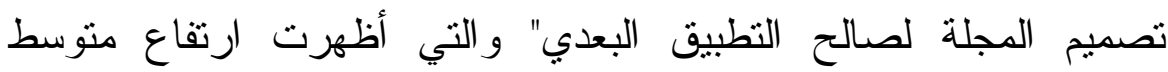
درجات المجموعة التجريبية (الطالبات المعلمات بكلية رياض الأطفال ) بالنسبة لبطاقة ملاحظة أداء الطالبات في تتفيذ الأنشطة الخاصة بالأطفال

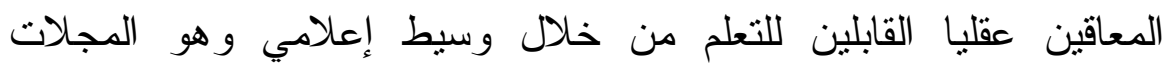

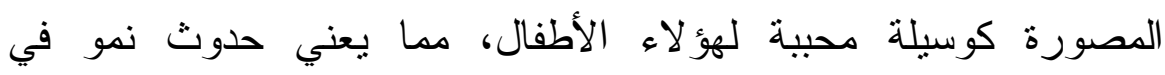

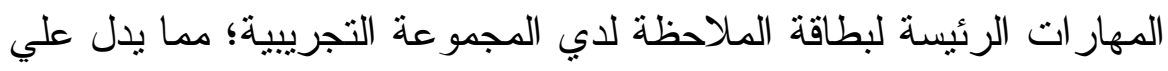

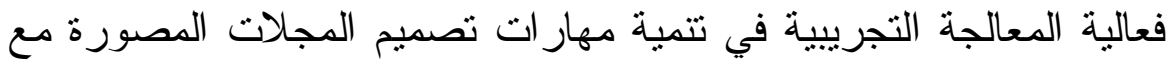
القدرة على تتمية مهار ات التعايش لدى هؤ لاء الأطفال.

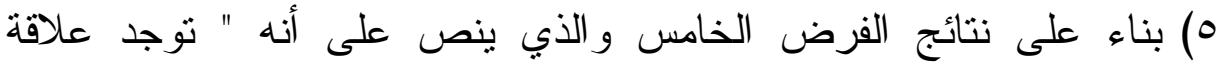

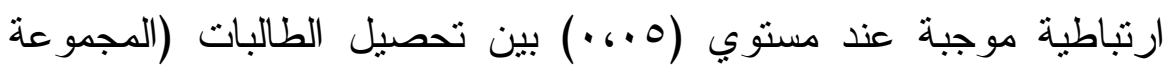

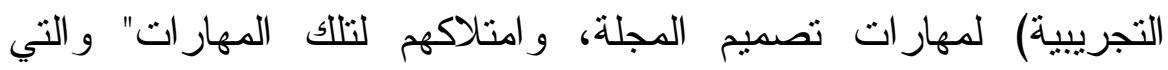


أظهرت علاقة ارتباطية موجبة ودالة إحصائيا عند مستوي ه.,. • بين كل من الجانب المعرفي لتصميم المجلات المصورة ومهار ات التصميم بما لإليا يعني تحقيق البرنامج لأهدافه بإكساب الطالبات المعلمات بكلية رياض الأطفال مهار ات تصميم المجلات المصورة اللازمة لتعليم الأطفال المعاقين عقليا القابلين للتعلم مهار ات التعايش.

$$
\text { ملخص نتائج الارسة: }
$$

لقد توصلت الاراسة الحالية إلى النتائج التالية:

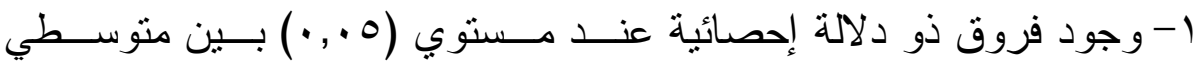
درجات طالبات المجموعتين (التجرييية و الضابطة) في النطبيـق البعـدي

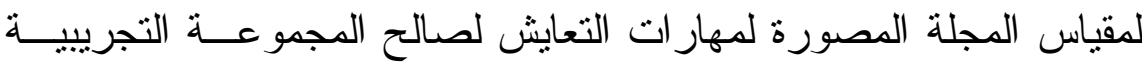
التي درست بالبرنامج المقتر ح.

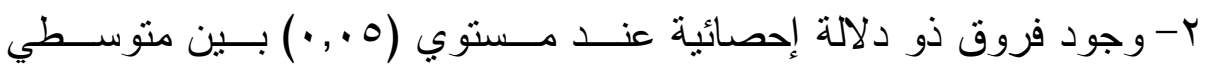
درجات طالبات (المجموعة التجريبية) في التطبيقـين (القبلـي و البعـدي) لمقياس المجلة المصورة لصالح التطبيق البعدي.

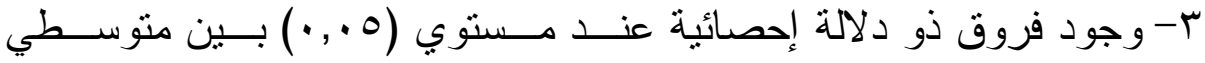
درجات طالبات المجموعتين (التجرييية و الضابطة) في التطبيـق البعـدي

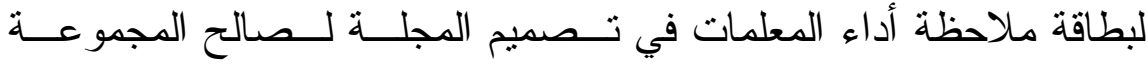
التجريية التي درست بالبرنامج المقترح.

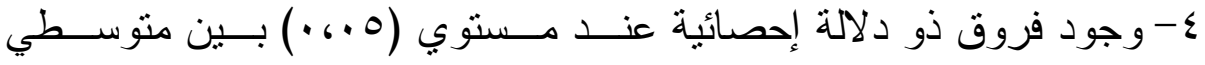
درجات طالبات (المجموعة التجريبية) في التطبيقـين (القبلـي و البعـدي) لبطاقة ملاحظة أداء المعلمات في تصميم المجلة لصالح النطبيق البعدي. 
0-وجود علاقة ارتباطية موجبة عند مستوي (0 ، •) بين تحصيل الطالبـات

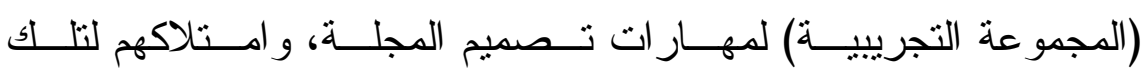

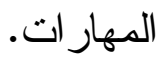

\section{توصيات ومقترحات الار اسة:}

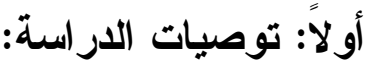

1- إقامة حملات عبر وسائل الاعلام لصالح بناء البيئات الافتر اضــية التـى

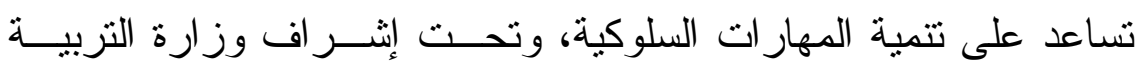

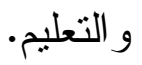

ץ- ضرورة انتشر الك كافة وسائل الاعلام فى تــصحيح الأفكــار و المفــاهيم

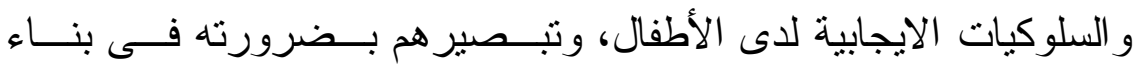

$$
\text { المجتمع الصحيح. }
$$

r- عقد الدور ات و الورش التذريبيية اللازمــة للمعلمـة لمـساعدتها علـى

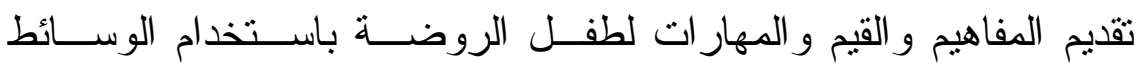

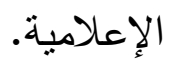

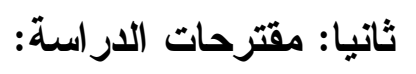

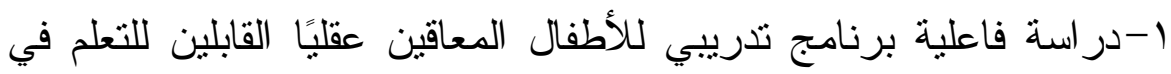

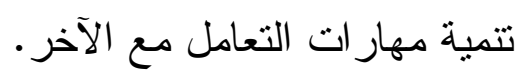

ץ-در اسة فاعلية برنامج إرشادي لمعلمي الأطفال المعاقين عقليًا فئة القابلين

للتعلم لتصميم بر امج إعلامية تخدم هذه الفئة. 
r-فاعلية برنامج تدريبي للأطفال المعاقين عقليًا القابلين للتعلم في تتيمة

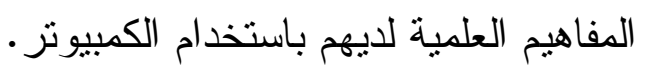

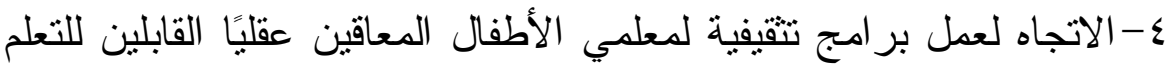

لتصميم الوسائل التعليمية الوسائط الإعلامية التي تساعدهم في تقديم الإنيم

الأنشطة لهم.

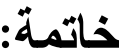

اتضح من تتاولنا لنتائج التحليل الإحصائى الخاص بنتائج الدر اسة الحالية،

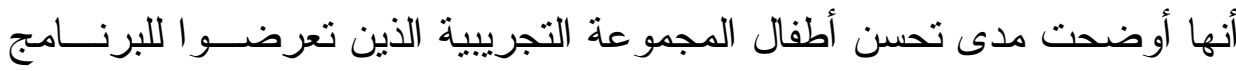

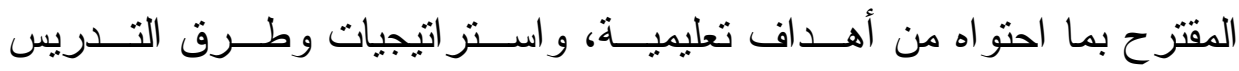

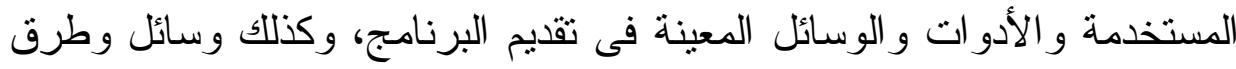

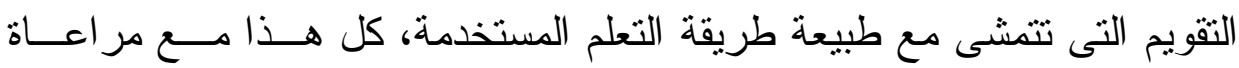
خصائص الأطفال فى هذه الفئة العمرية، وقد تبين أن الأطفال تحسنت سلوكياتهم

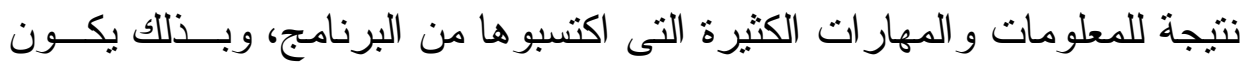
البرنامج قد حقق الهدف الرئيسى وهو تتمية بعض مهارات التعايش لدى الأطفال المعاقين عقليا (القابلين للتعلم). 


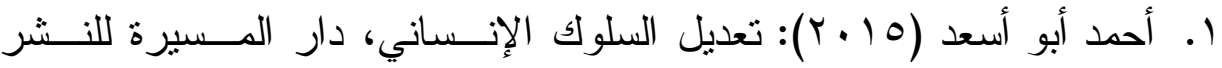

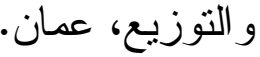

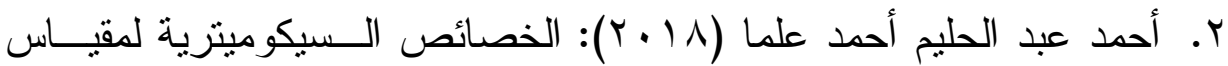

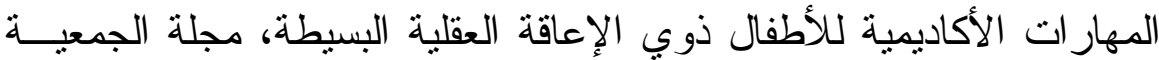

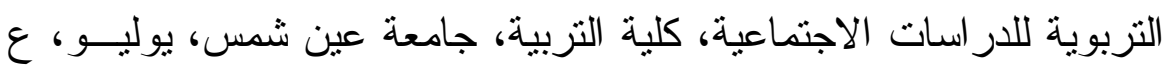
$.04-1161 \cdot r$

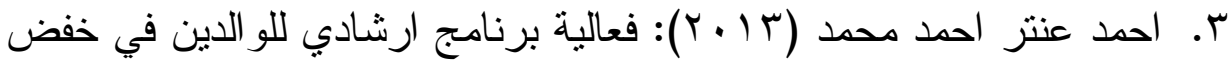
الاضطر ابات السلوكية لاي أطفالهم ذوي الإعاقة العقلية البـسيطة القـابلين

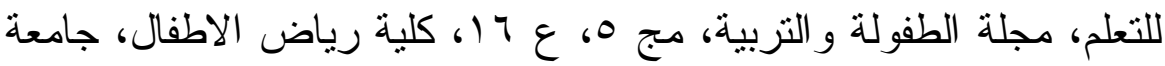

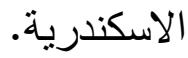

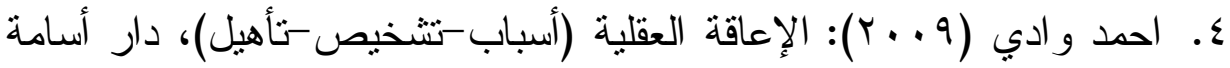
للنشر و التوزيع، عمان.

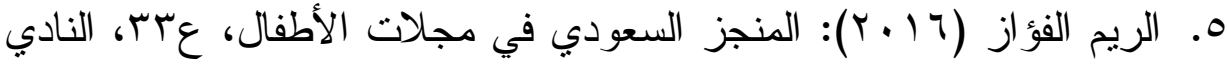
الأدبي، قو افل، الرياض، المملكة العربية السعودية.

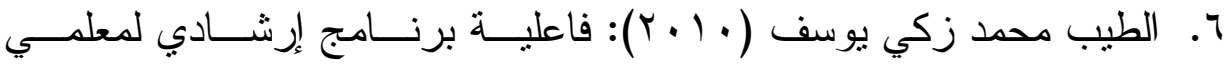

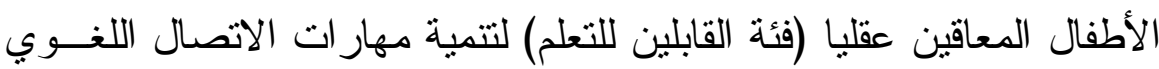

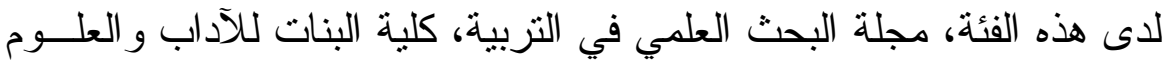

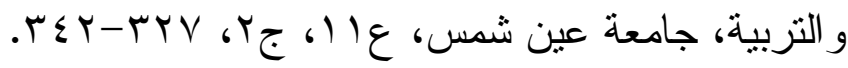




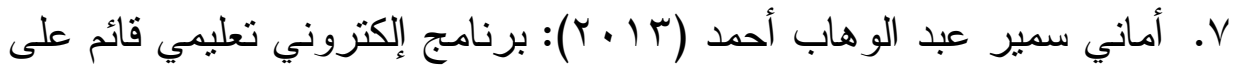

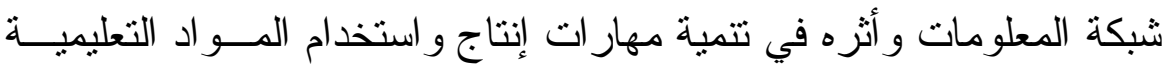
اللازمة لبر امج الدمج للطالبة المعلمة برياض الأطفال، رسالة دكتور اه غير فيرال منشورة، كلية التربية، جامعة دمياط.

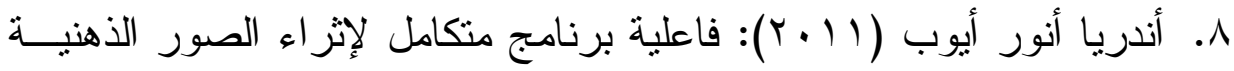

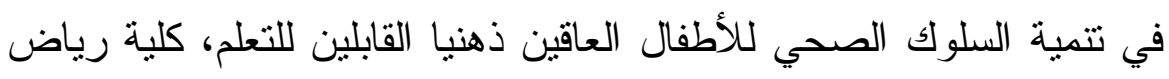

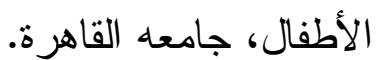

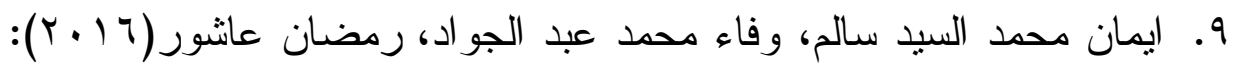
جودة الحياة وعلاقتها بالكفاءة الوالدية لدي امهات الاطفال المعاقين عقليــا.

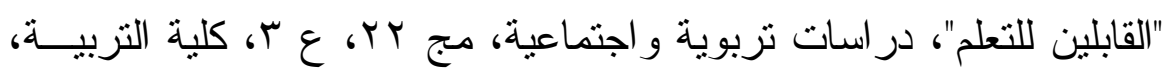

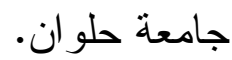

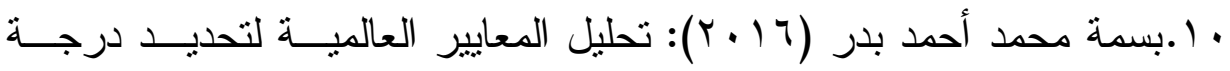

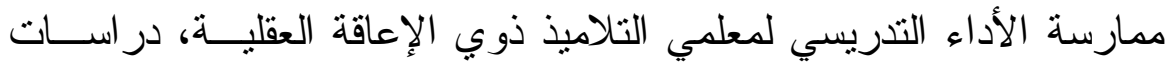

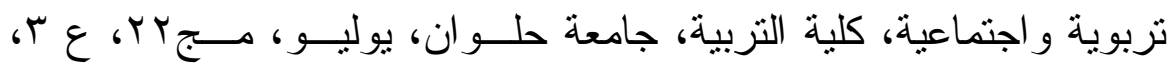
$.|0 \Lambda-| Y \mid$

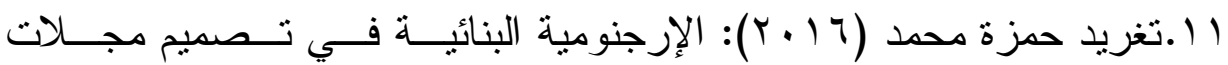
الأطفال، المكتب العربي للمعارف، القاهرة.

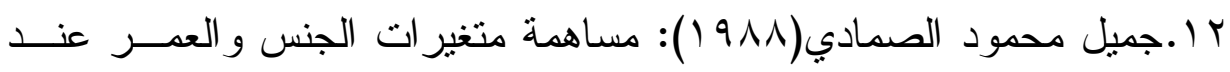
الإصابة بالإعاقة والحالة الاجتماعية و الحالة الصحية و المستوى الاقتصادي

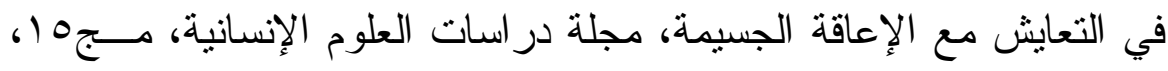
$.9 \cdot-v r$ ، 


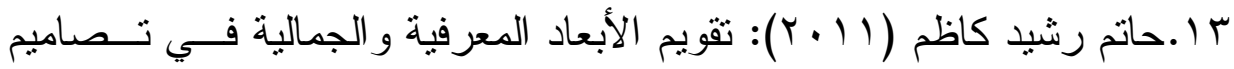

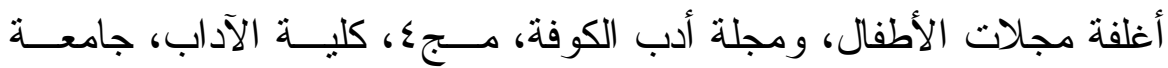

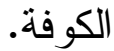

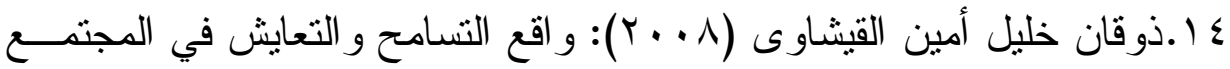
الفلسطيني، ورقة عمل مقدمة الى ملتقى الحريات الثاني، فلسطين.

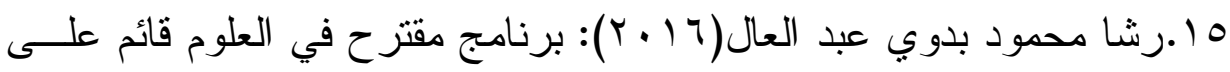

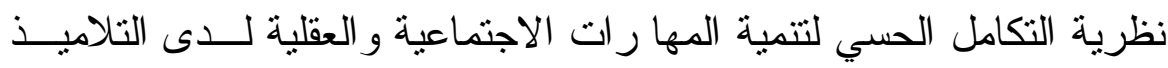

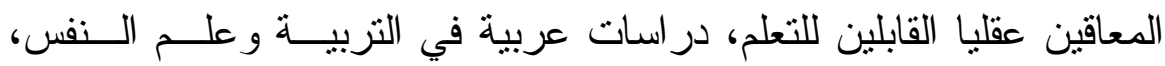
رابطة التزبويين العرب، عqجان، القاهرة.

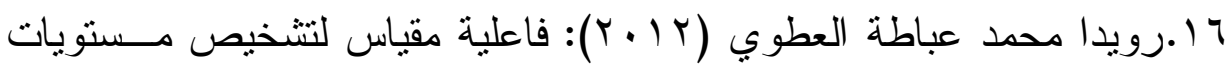

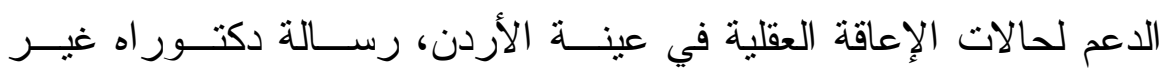
منشورة، كلية الدراسات العليا، الجامعة الأردنية.

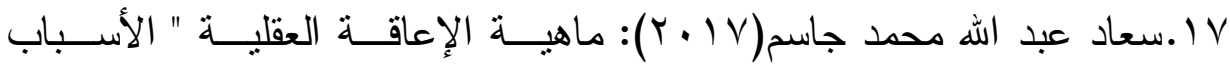

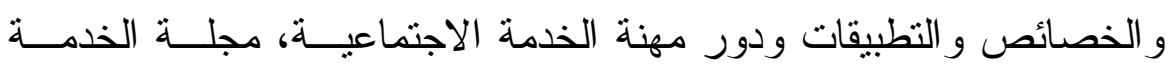

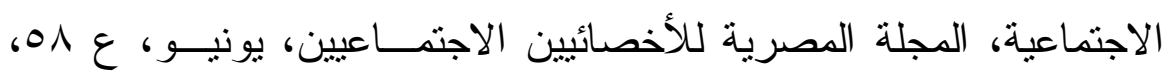
ج

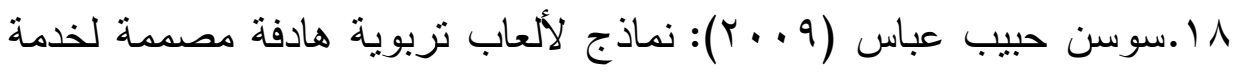

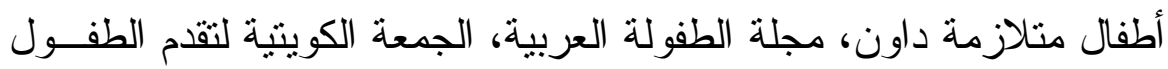

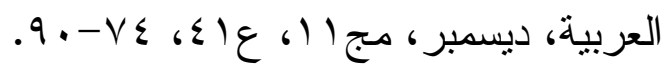


9 ا.شريف درويش اللبان(r ( ـ r): استخدام الطلاب ذوي الاحتياجات الخاصسـة

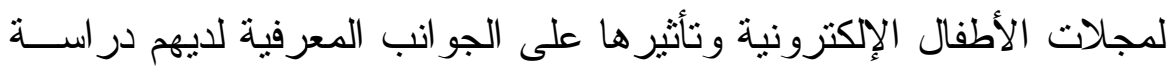
شبه تجرييية، المؤتمر اعلمي السنوي العربي الر ابع: إدارة المعرفــة وإدارة

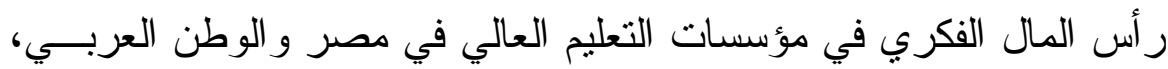

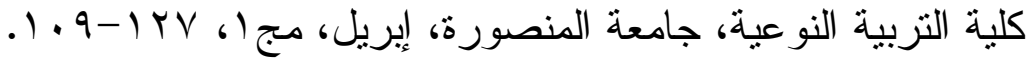

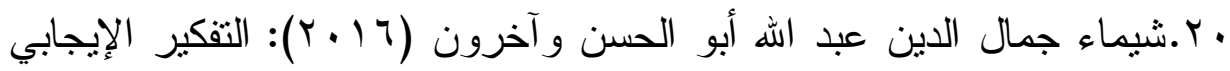
لعينة من الأمهات و أثره في السلوك التكيفي لأطفالهن المعاقين عقليا القابلين الإني

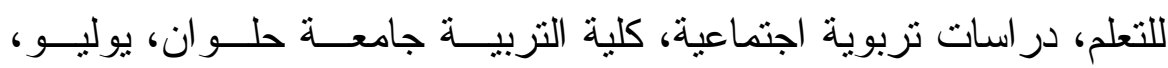

$$
\text { مجrr }
$$

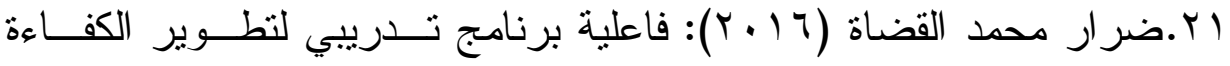

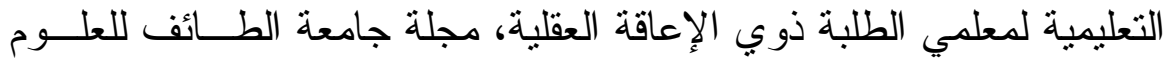

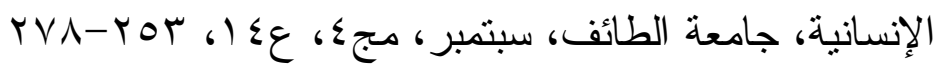

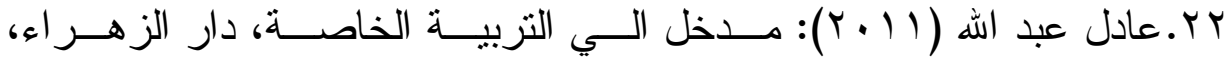
الرياض، المملكة العربية السعودية.

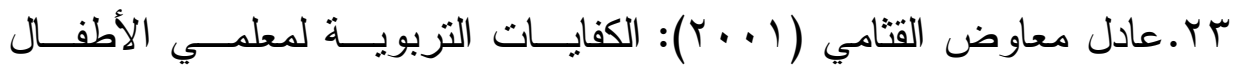

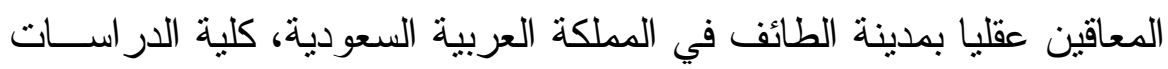
العليا، الجامعة الأردنية، عمان.

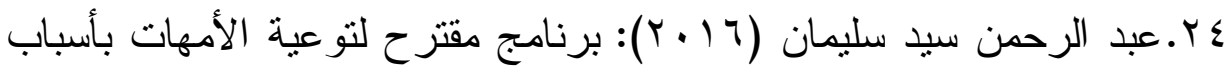

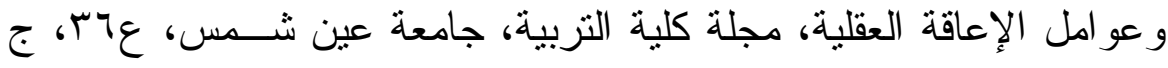
$. V V 1-V 01,4$ 


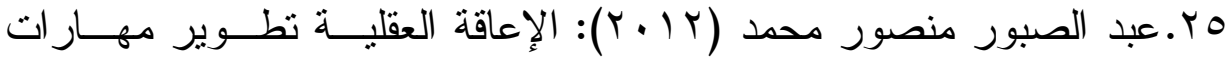
السلوك الاجتماعي في الحياة اليومية، دار الكتاب الحديث، القاهرة.

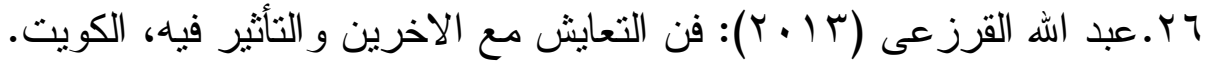
rV.rV الأطفال الدتخلفين عقليا، مجلة جامعة سبها للعلوم الإنسانية، جامعة ســبها،

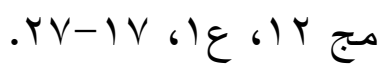

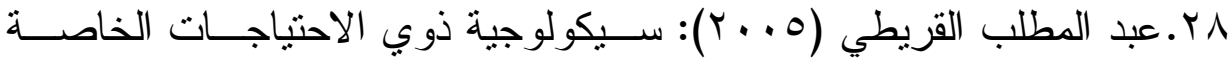
وتربيتهم، دار الفكر العربي، القاهرة.

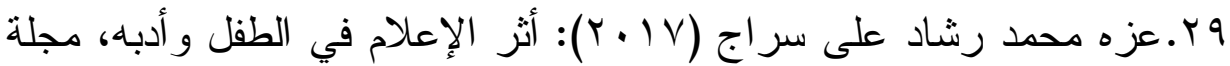
كلية الآداب، عq، كلية الآداب، جامعة بورسعيد.

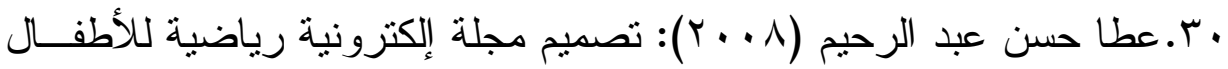

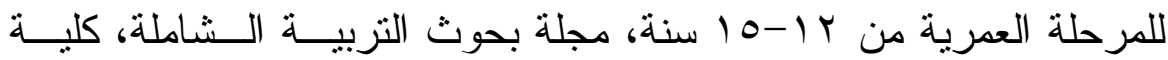

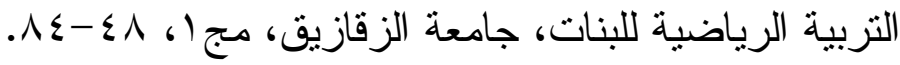

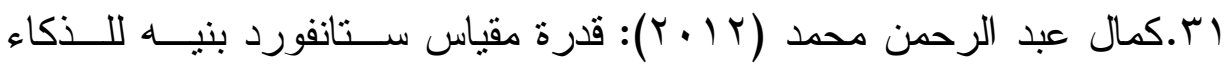
الإصدار الخامس على التمييز بين العاديين وذوي صعوبات الــتعلم وذوي

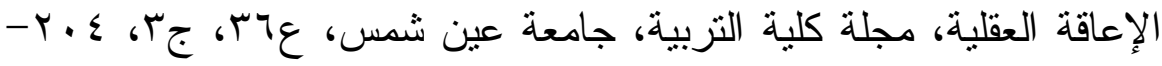
$.4+\sin$ Yr.لمياء البحيري (T + . Y): مظاهر المنافسة بين مجلات الأطفال المـصرية،

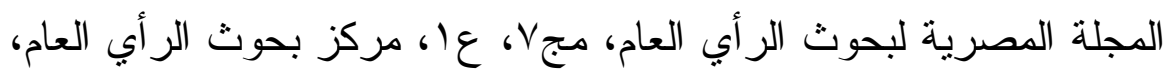

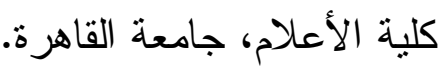




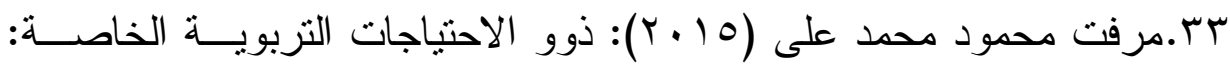

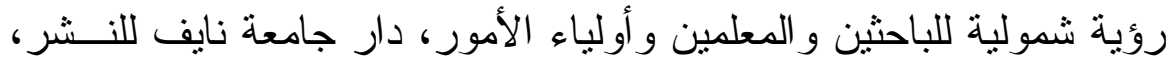
الرياض، المملكة العربية السعودية.

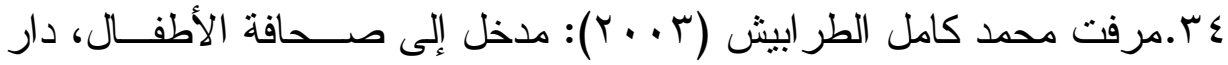

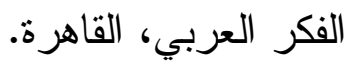

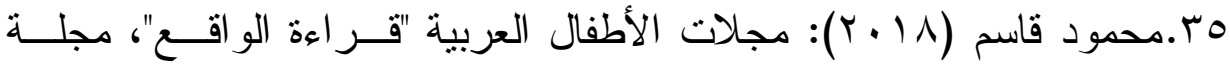
الطفولة و التتمية، ع r؟، المجلس العربي للطفولة و التتمية، القاهرة.

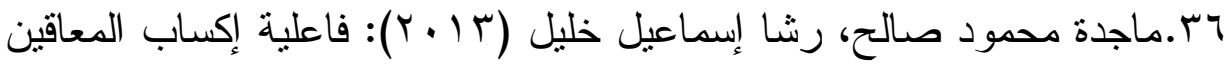
عقليا القابلين للتعلم بعض الدفاهيم الزمنية باستخدام الأنشطة التزبوية، مجلة القر اءة و المعرفة، ع بـا 1، كلية التزبية، جامعة عين شمس.

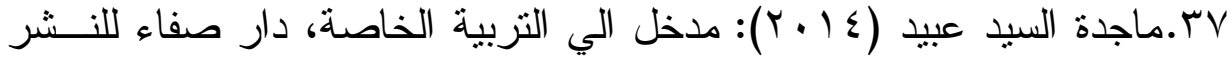

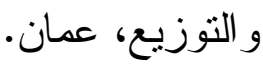

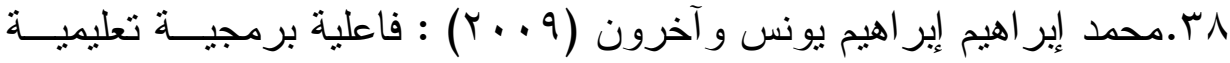

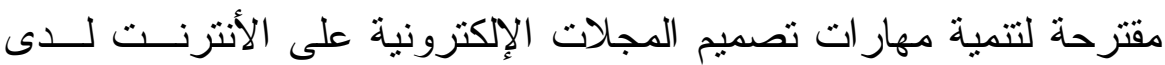

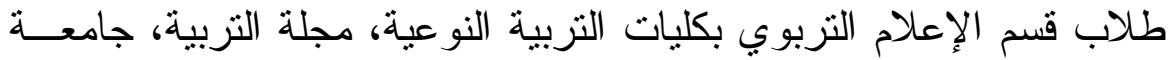

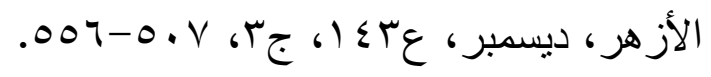

9 ب.محمد محمود أحمد شحاته (ب99 (1)): طــرق الأداء التـصميمية وتتـسيق صفحات قصة الطفل، مجلة تكنولوجيا التعليم، الجمعية المصرية لتكنولوجيا

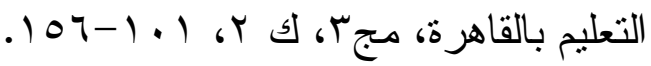




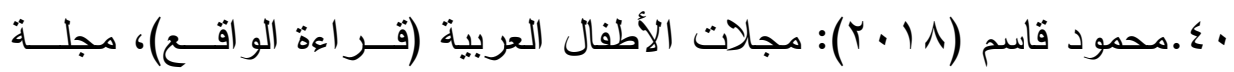

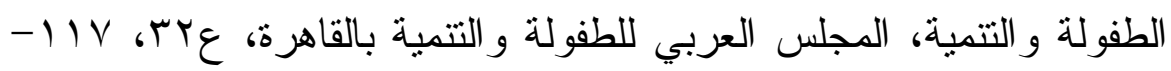

1ـ.مصطفى رجب (997 (1): الرسوم في مجلات الأطفال و أهميتها التزبويــة،

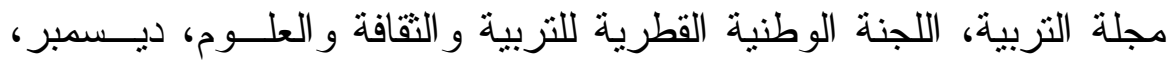

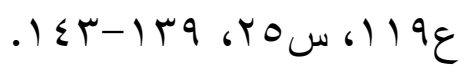

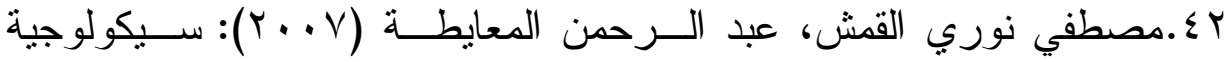

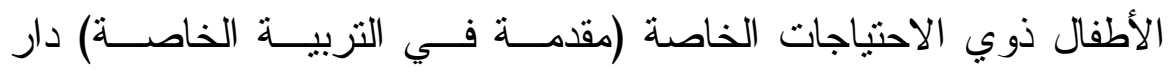

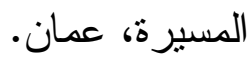

rع.مصطفي نوري القمش (10 • ب) الإعاقة العقلية - النظرية و الممارســة، ط

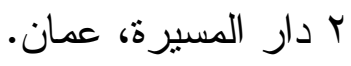

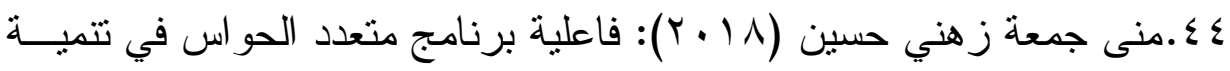

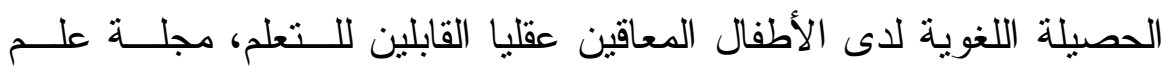

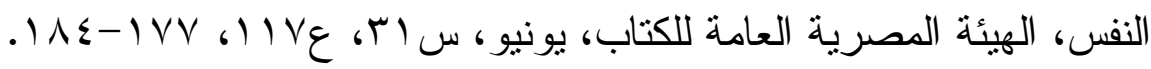

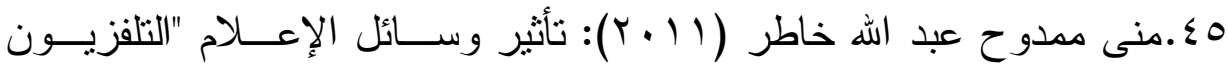
وصحافة الطفل" على بعض المتغير ات النفسية لاى الطفل المصري، مجلـــة

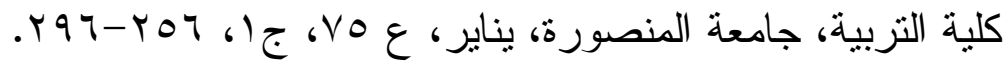

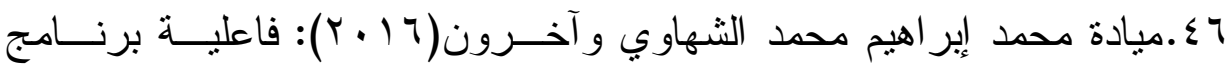
إرشادي قائم على نظرية التعلم الاجتماعي في تتمية بعض مهارات الحيـاة 
اليومية لدى الأطفال المعاقين عقليا القابلين للتعلم، مجلة كلية التربية، جامعة

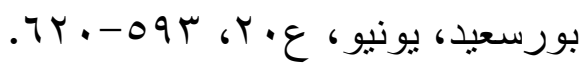

VI Vاصر بن سعد العجمي، عبد الهادي بن مبارك الدوسري (10 • ب): التحقق

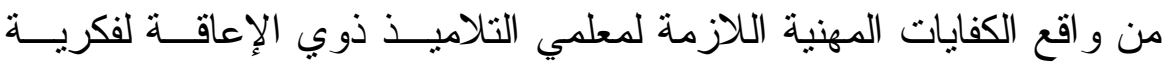
و أهميتها من وجهة نظر هم بمدينة الرياض، دراسات عربية فــي التزبيــة و علم النفس، رابطة التربويين العرب، ع • • القاهرة.

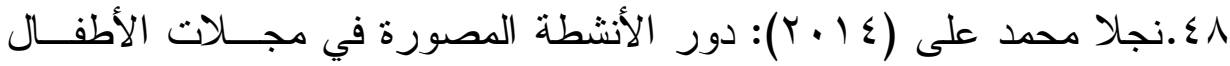

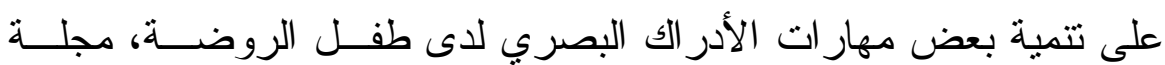

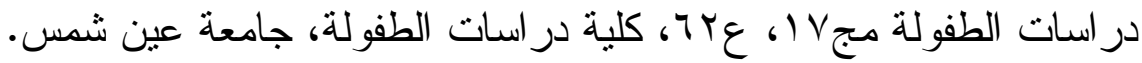
9 §. هالة سعيد إيهاب (ع ا ـ r): إخر اج الصورة الصحفية في مجلات الأطفال، المكتب العربي للمعارف، القاهرة. •. هدى محمد قناوي (71911): در اسة تحليلية لمحتوى مجلات الأطفال فـي

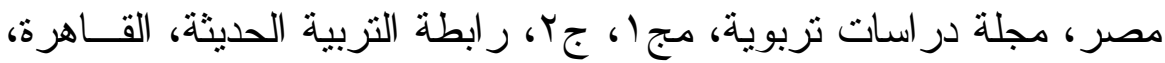

$$
\text { . } \vee 1-r q
$$

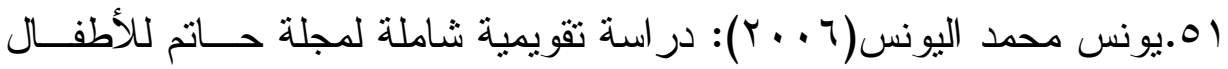
الصادرة عن المؤسسة الصحفية الاردنية الر أي، دراسات العلوم التربويــة

$$
\begin{aligned}
& \text { مجبr"، عا، الجامعة الأردنية. } \\
& \text { ثانيا: المراجع الأجنبية: }
\end{aligned}
$$

52. Luckasson,R.S; charlock,R.(2004): American on mental Retardations Definition classification and system of supports and Its Relation to International Trends and 
issues In the field of intellectual disabilities journal of policy and practice In Intellectual disabilities vol 1 No 34pp .136-146 September/ December

53. Morrow,m, lesnick.j, (2001): examining the educational value of children's magazines, the California reader, 34 (2) 1-17(available on line: http://www.childmag.month.org )

54. Pugach,M.C. \& warger,C.L.(2001): Curriculum Matters: Raising Expectation for Students with learning disabilities remedial and Special Education, 220-219.

55. Sdanki,J., khetan,j., Gupta,s., tomar‘D., singh`m. (2015): oral rehabilitation management of mentally restarted, journal of clinical diagnostic research, vol(9), no (1), pp. $1-6$

56. stoll,Donald (1977) magazine for kids steens new JerseyInternotional reading association.

57. Sharon,Y.(2008): supporting beginning special Education "Teachers of students with law in cadence DISSBILITIES IN URBAN SETTING .CAPELLA UNIVERSITY,JULY.

58. Wells,Robert,E. (2002): How Do you know what time it is? Albert Whitman \& company. 